\title{
Vapor pressure and specific electrical conductivity in the solid and molten H2O-CsH2PO4-CsPO3 system-a novel electrolyte for water electrolysis at $\sim 225-400{ }^{\circ} \mathrm{C}$
}

Nikiforov, Aleksey Valerievich; Berg, Rolf W.; Bjerrum, Niels J.

Published in:

lonics

Link to article, DOI:

$10.1007 / \mathrm{s} 11581-017-2420-3$

Publication date:

2018

Document Version

Peer reviewed version

Link back to DTU Orbit

Citation (APA):

Nikiforov, A. V., Berg, R. W., \& Bjerrum, N. J. (2018). Vapor pressure and specific electrical conductivity in the solid and molten $\mathrm{H}_{2} \mathrm{O}-\mathrm{Cs} \mathrm{H}_{2} \mathrm{PO}-\mathrm{CsPO}_{3}$ system-a novel electrolyte for water electrolysis at $\sim 225-400{ }^{\circ} \mathrm{C}$. lonics, 24(9), 2761-2782. hitps: Iddoi.org $910.1007 / \mathrm{s} 11581-017-2420-3$

\section{General rights}

Copyright and moral rights for the publications made accessible in the public portal are retained by the authors and/or other copyright owners and it is a condition of accessing publications that users recognise and abide by the legal requirements associated with these rights.

- Users may download and print one copy of any publication from the public portal for the purpose of private study or research.

- You may not further distribute the material or use it for any profit-making activity or commercial gain

- You may freely distribute the URL identifying the publication in the public portal 


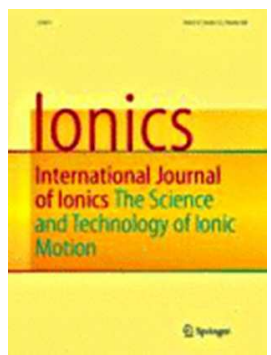

\section{Vapor pressure and specific electrical conductivity in the solid and molten $\mathrm{H}_{2} \mathrm{O}-\mathrm{CsH} \underline{2} \mathrm{PO} \underline{4}-\mathrm{CsPO} \underline{3}$ system - A novel electrolyte for water electrolysis at 225-400 ${ }^{\circ} \mathrm{C}$}

\begin{tabular}{|r|l|}
\hline Journal: & Ionics \\
\hline Manuscript ID & IONICS-2017-0717 \\
\hline Manuscript Type: & Original Papers \\
\hline Date Submitted by the Author: & $27-S e p-2017$ \\
\hline Complete List of Authors: & $\begin{array}{l}\text { Nikiforov, A.V.; Technical Unversity of Denmark, DTU Energy, Kemitorvet } \\
207 \\
\text { Berg, Rolf; Technical University of Denmark, DTU Chemistry } \\
\text { Bjerrum, Niels; } 1, \text { DTU Energy }\end{array}$ \\
\hline Keywords: & $\begin{array}{l}\text { CDP, ionic conductivities, phosphate-based electrolyte, elevated } \\
\text { temperature pressure electrolysis, H<sup }>+</ \text { sup }>\text { Conductor }\end{array}$ \\
\hline
\end{tabular}

\section{SCHOLARONE ${ }^{\text {M }}$}

Manuscripts 


\title{
Vapor pressure and specific electrical conductivity in the solid and molten $\mathrm{H}_{2} \mathrm{O}-\mathrm{CsH}_{2} \mathrm{PO}_{4}$ - $\mathrm{CsPO}_{3}$ system - A novel electrolyte for water electrolysis at $\sim 225-400{ }^{\circ} \mathrm{C}$
}

\author{
A. V. Nikiforov ${ }^{a}$, R. W. Berg ${ }^{b^{*}}$ and N. J. Bjerrum ${ }^{a}$ \\ ${ }^{(a)}$ DTU Energy, Technical University of Denmark, Kemitorvet, 207, DK-2800 Kgs. Lyngby, \\ Denmark, nava@dtu.dk, nibj@dtu.dk \\ ${ }^{(b)}$ DTU Chemistry, Technical University of Denmark, Kemitorvet, 207, DK-2800 Kgs. Lyngby, \\ Denmark, rwb@kemi.dtu.dk
}

\section{Running head: $\quad \mathrm{CsH}_{2} \mathrm{PO}_{4}$ for water electrolysis at $\sim 225-400{ }^{\circ} \mathrm{C}$}

\begin{abstract}
Cesium dihydrogen phosphate, $\mathrm{CsH}_{2} \mathrm{PO}_{4}$ (CDP) was studied for water electrolysis at $\sim 225-400{ }^{\circ} \mathrm{C}$. In presence of sufficient humidity, CDP is structurally disordered and super-protonic conducting with conductivities reaching $0.2-0.25 \mathrm{~S} \mathrm{~cm}^{-1}$, when determined in suitable $\mathrm{H}$-shaped sealed conductivity-cells. Freshly prepared $99.7 \pm 0.3 \%$ gravimetric pure CDP with correct X-ray diffraction and DSC diagram melted at $\sim 345^{\circ} \mathrm{C}$. The vapor pressures, above CDP alone and mixed with $20-$ $50 \mathrm{~mol} \% \mathrm{CsPO}_{3}$ or $13 \mathrm{~mol} \% \mathrm{H}_{2} \mathrm{O}$, were determined in sealed ampoules up to $355^{\circ} \mathrm{C}$ by means of Raman spectroscopy based on internal reference-gases. Pressures up to $\sim 49$ bar were estimated, much higher than previously expected. Conductivities were given as polynomials and plotted in solid and liquid states. Water splitting electrolysis $2 \mathrm{H}_{2} \mathrm{O} \rightarrow 2 \mathrm{H}_{2}+\mathrm{O}_{2}$ was demonstrated by Raman at $\sim 355^{\circ} \mathrm{C}$ under a water pressure of $\sim 23$ bar in a quartz cell with platinum electrodes, showing molten CDP to have significant potential for water electrolysis.
\end{abstract}

Keywords: CDP, ionic conductivity, $\mathrm{H}+$ conductor, phosphate-based electrolyte, elevated temperature pressure electrolysis 


\section{Introduction}

Water electrolysis represents an attractive way to convert surplus electrical energy into chemical energy (hydrogen and oxygen) to balance the electric grid when an increasing fraction of the power input originates from fluctuating renewable sources such as solar and wind energy [1]-[2]. Using fuels such as synthesis gas and methanol in intermediate temperature solid electrolyte fuel cells at elevated temperatures has several advantages, among which the following can be mentioned: opportunity for better storage of excess energy, improved catalytic activity or possibility to replace noble metals with cheaper electro catalytic materials, more effective use of waste heat, and lower permeability through the electrolyte in comparison with current commercial polymer-electrolyte fuel cells (PEFCs) [3]-[4].

In all kinds of fuel cell and water electrolyzer systems the electrolyte is one of the most important features directly influencing performance. The magnitude of the specific proton conductivity is a key parameter that influences the system in several ways, such as operating temperature, permitted range of chemical composition, allowed humidity and associated water vapor pressure above the electrolyte.

We recently demonstrated that molten potassium dihydrogen phosphate $\left(\mathrm{KH}_{2} \mathrm{PO}_{4}\right.$, or $\left.\mathrm{KDP}\right)$ could be a promising proton-conducting molten electrolyte for pressurized intermediate temperature water electrolysis, and observed a high conductivity $\left(\sim 0.30 \mathrm{~S} \mathrm{~cm}^{-1}\right.$ at $\left.300^{\circ} \mathrm{C}\right)$ at pressures around 10 atm. [5]-[6]. However KDP is just one member of a whole family of proton-conducting electrolytes, salts with properties intermediate between a normal salts and acids, see e.g. [7]-[16].

Exceptional high conductivity $\left(\sim 2.2 \times 10^{-2} \mathrm{~S} \mathrm{~cm}^{-1}\right)$ has been discovered for solid cesium dihydrogen phosphate $\left(\mathrm{CsH}_{2} \mathrm{PO}_{4}\right.$ or CDP) above its transition to a so-called superionic or "superprotonic" proton-conducting phase at about $230{ }^{\circ} \mathrm{C}$. The CDP crystal also undergoes a proton ordering ferro- to para-electric phase transition at low temperature, at about $-119{ }^{\circ} \mathrm{C}$ [17][23] that will not be considered here. The successful use of the CDP salt as a promising solid electrolyte was demonstrated in intermediate temperature fuel cells, sometimes with composite electrolyte membranes to stabilize the conductivity at temperatures up to $\sim 250{ }^{\circ} \mathrm{C}$ [12], [21], [24][44]. Thus CDP seems to be one of the most widely studied solid acid electrolytes. However, when $\mathrm{CsH}_{2} \mathrm{PO}_{4}$ is heated in air at atmospheric pressure dehydration takes place (it starts to lose weight) at about the same temperatures [4], [13], [45]-[48]. Under conditions of high humidity the transformation is reversible and water can be picked up again, but under dry conditions, the dehydration of CDP (Eq. (1)) proceeds to form polymerization products (hydrogen pyrophosphates and polyphosphates) at temperatures above $\sim 200{ }^{\circ} \mathrm{C}$ until complete decomposition to the metaphosphate $\mathrm{CsPO}_{3}$ at still higher temperatures:

$$
2 \mathrm{CsH}_{2} \mathrm{PO}_{4} \rightarrow \mathrm{Cs}_{2} \mathrm{H}_{2} \mathrm{P}_{2} \mathrm{O}_{7}+\mathrm{H}_{2} \mathrm{O} \rightarrow \frac{2}{n}\left(\mathrm{CsPO}_{3}\right)_{n}+2 \mathrm{H}_{2} \mathrm{O} \quad(n=1,2,3, \ldots)
$$

Since this dehydration reaction occurs in parallel with the transition to the superprotonic phase, the nature of CDP phases and the conduction mechanism has been much discussed over the last decades [4], [9], [12], [19], [21]-[23], [26]-[27], [33], [35], [38], [44], [46]-[63]. The phase diagram in the $\mathrm{CsH}_{2} \mathrm{PO}_{4}-\mathrm{CsPO}_{3}$ system was studied in e.g. refs. [19], [46]-[47], [55]. Stabilization of the superprotonic phase without any decomposition was demonstrated under appropriate humid conditions in e.g. crystallographic and electrochemical studies [4], [26], [53]. It was found that CDP 
is stable in contact with $\mathrm{Pt}$ catalysts in oxidizing and reducing atmospheres up to at least $240{ }^{\circ} \mathrm{C}$ [12], [27], [46].

It was even proven that the CDP at high pressures (up $25 \mathrm{kbar}$ ) did not decompose prior to melting when heated up to $\sim 460{ }^{\circ} \mathrm{C}$ [19], [22]-[23], [61]. Various melting points for CDP have been reported in the literature under different experimental conditions (pressure, confinement and water partial pressure) but the correct value is thought to be around $345-349{ }^{\circ} \mathrm{C}$ at pressures near ambient values [19], [38], [55], see Figure 1.

The crystal structure of $\mathrm{CsH}_{2} \mathrm{PO}_{4}$ (space group $P 2_{1} / m$ ) at ambient temperature and pressure has a unique hydrogen-bond network [49] [64]. The lattice constants in this monoclinic paraelectric phase II are around $a=7.912 \AA, b=6.383 \AA, c=4.882 \AA, \beta=107.73^{\circ}$, and each unit cell contains two formula units. The tetrahedral phosphate anions $\left[\mathrm{PO}_{4}\right]^{3-}$ are linked via two kinds of partly disordered one-dimensional $\mathrm{O}-\mathrm{H} \cdots \mathrm{O}$ hydrogen bonds forming layers of $\left[\mathrm{H}_{2}\left(\mathrm{PO}_{4}\right)^{-}\right]_{\infty}$ with room for $\mathrm{Cs}^{+}$cations at sites in between these layers (according to e.g. [17]-[18], [21]-[23], [65]-[67]).

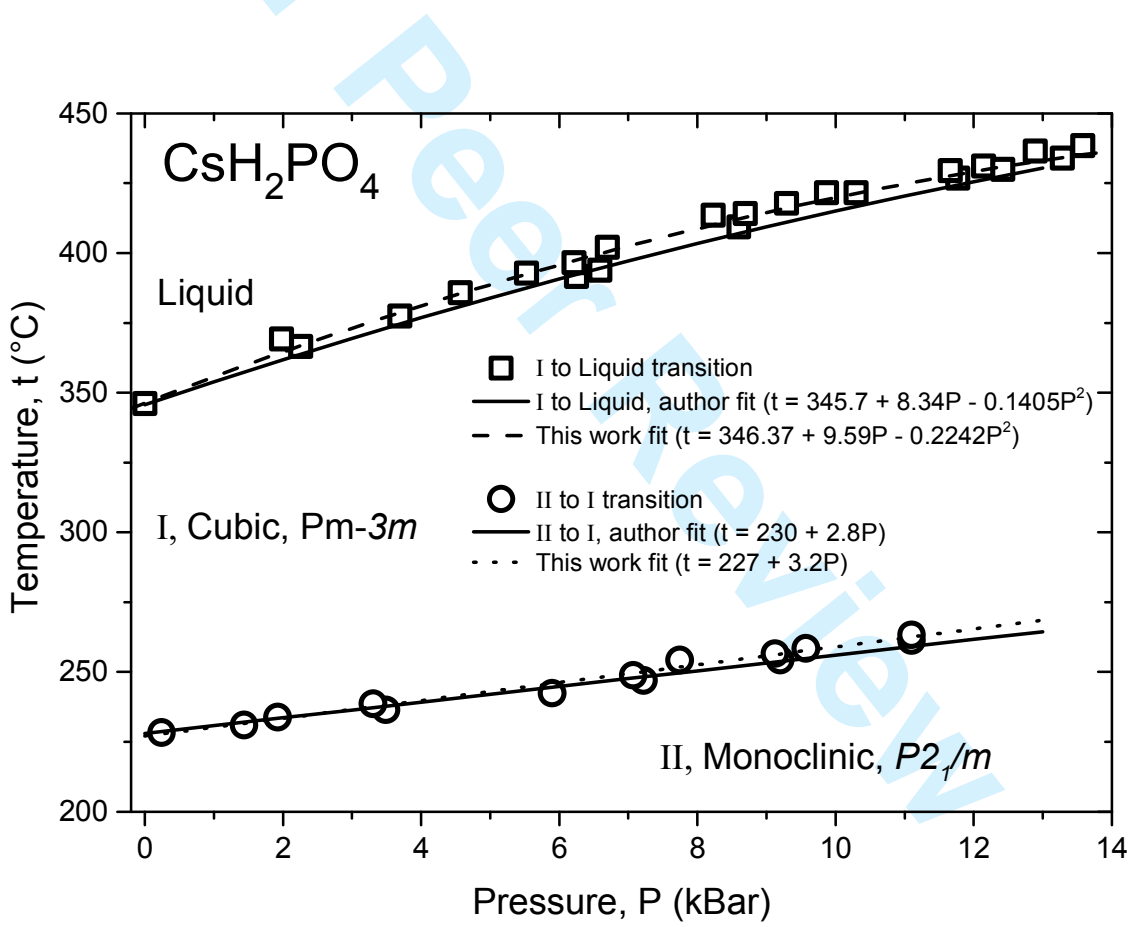

Figure 1. Pressure - temperature phase diagram of $\mathrm{CsH}_{2} \mathrm{PO}_{4}$ based on data by Rapoport et al. [19]. Their results were obtained from DSC heating experiments of samples confined in pressurized $\mathrm{Ni}$ capsules. "Post mortem" X-ray powder diffraction experiments confirmed the absence of any decomposition of the CDP. The points and curves shown reproduce the author data (points and polynomials of the type: Temperature $=$ an expression of pressure [19]. Positions for each author point were read manually pixel by pixel from an expanded plot relatively to the axis values by use of the open source GIMP 2.9.6 software (GNU Image Manipulation Program designed for the GNU Operating System from the Free Software Foundation, Inc. in Boston, MA, USA). The dotted-dashed curves obtained in this work fit better to the original data. 
By heating $\mathrm{CsH}_{2} \mathrm{PO}_{4}$ above $\sim 228-231{ }^{\circ} \mathrm{C}$, the monoclinic structure (phase II) transforms to the cubic phase I that has been characterized as a CsCl-like structure in space group no. $221, P m \overline{3} m$, with $Z=1$ and a lattice constant of $a=\sim 4.96 \AA$, with one phosphate anion placed in the center of the cube and with Cs atoms at each corner (see Figure 2). This 'superprotonic phase' exhibits its superconducting properties after a sudden increase in the conductivity by three orders of magnitude, from about $10^{-5}$ to $2.210^{-2} \mathrm{~S} \mathrm{~cm}^{-1}$ [4], [7]-[9], [12], [21]-[22], [26], [46]-[47], [49]-[50], [61], [69]-[70]. The role of the phase transformation is thought to be to set the disordered hydrogen bond network free to easily transport protons. The oxyanion can take one of six possible orientations within the cube and therefore the hydrogen bonds can be formed in six possible ways. In this state the phosphate groups are linked together with hydrogen bonds of two different kinds: symmetric double minima and asymmetric single minimum bonds. The proton transfer is thought to happen rapidly via the hydrogen bonds and liberations or reorientation jumps of the $\left[\mathrm{PO}_{4}\right]^{3-}$ anions influenced by phosphate group disorder [21], [26], [49], [53], [69]. Details of the mechanism for the high proton mobility are considered in several references involving many techniques including neutron scattering and nuclear magnetic resonance [12]-[14], [27]-[29], [36], [41], [51]-[52], [67], [68], [71]-[74].

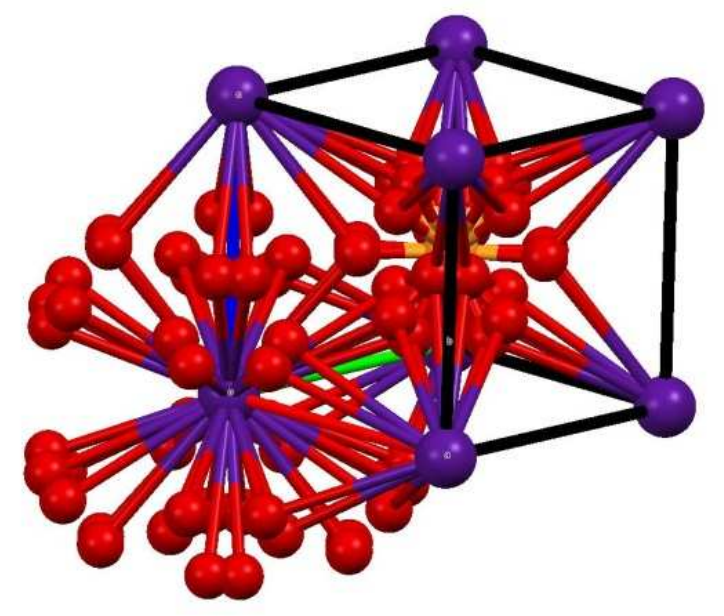

Figure 2. The crystal structure of $\mathrm{CsH}_{2} \mathrm{PO}_{4}$ in the "superprotonic" phase I is well established with $a=$ 4.961(3) $\AA$ at $237{ }^{\circ} \mathrm{C}$ [53] [22] and with $a=$ 4.9549(4) $\AA$ at $242{ }^{\circ} \mathrm{C}$ [68]. The $\mathrm{Cs}^{+}$ions at cell corners are shown in violet. The yellow $\mathrm{P}$ ion in the middle of the cell is not visible. The four oxygen ions are disordered and red balls show their positions that are occupied with a 0.16667 probability. The hydrogen ions (not shown) are also disordered. The picture was created by use of single crystal data from [68] and the "CCDC Mercury program" from www.ccdc.cam.ac.uk.

An important role must also be played by the water present in humidified surroundings or by the containments obstructing the decomposition that would otherwise happen. Thus in many of the references, decomposition or dehydration of the CPD was considered and it was often noted that polymerization products were formed at higher temperature making the conductivity decrease as time elapsed [4], [22].

The decomposition has been claimed to be reversible, and a water pressure of, for example 0.3 atm. at $250{ }^{\circ} \mathrm{C}$ should be sufficient to suppress dehydration for some time [4] [26]. It was reported that the conductivity of $\mathrm{CsH}_{2} \mathrm{PO}_{4}$ started to decrease when heated above $238{ }^{\circ} \mathrm{C}$ and it was claimed to be due to the decomposition reaction (1) $\mathrm{CsH}_{2} \mathrm{PO}_{4} \rightarrow \mathrm{Cs}_{2} \mathrm{H}_{2} \mathrm{P}_{2} \mathrm{O}_{7} \rightarrow \mathrm{CsPO}_{3}$ and that water saturation or high pressures were needed to avoid it [23], [46]-[47], [55], [61]. Taninouchi et 
al. [46], [55] have directly related the onset Kelvin temperature of dehydration ( $\left.T_{\text {dehy }}\right)$ to the water partial pressure $\left(\mathrm{pH}_{2} \mathrm{O}\right.$ in atm.) by means of extrapolated equations (Eq. (2)):

$$
\log \left(\mathrm{pH}_{2} \mathrm{O} / \mathrm{atm} .\right)=\mathrm{A}-\mathrm{B} \times 1000 / T_{\text {dehy }}
$$

where $A=(6.11 \pm 0.82)$ or $(7.62 \pm 1.18)$ and $B=(3.63 \pm 0.42)$ or $(4.42 \pm 0.56)$ are parameters.

Whether the "superionic conduction state" in CDP really exists is still questioned by some reseachers: Could the high conductivity above $\sim 230{ }^{\circ} \mathrm{C}$ be a consequence of partial dehydration at the crystal surface? [51]-[52], [62]. It has been claimed that CDP does not undergo the superprotonic phase transition; instead a dynamically disordered hydrogen bond network might improve the protonic conduction, or a loss of water from the structure might raise the conductivity. However, we notice that many previous experiments were not performed at humidified conditions and many studies have shown the highly-conducting CDP phase to be poorly stable under reduced presence of water [4], [46]-[47], [53], [55]. Thus in a typical study, Bronowska [53] concluded from high temperature X-ray experiments in normal air that CDP crystal powders underwent a "reversible" transition at $\sim 231{ }^{\circ} \mathrm{C}$ to form $\mathrm{Cs}_{2} \mathrm{H}_{2} \mathrm{P}_{2} \mathrm{O}_{7}$ but also transformed to the superionic phase which however was unstable due to dehydration, soon leading to the formation of $\mathrm{CsPO}_{3}$; but in a $\mathrm{H}_{2} \mathrm{O}$-saturated atmosphere much less decomposition was seen for the same CDP powders. In other words, the superionic phase of CDP seems to require a sufficient water vapor pressure over the salt, in which case the transition to the superionic phase takes place reproducibly.

Many ingenious chemical studies (such as substitution of $H$ with $D, C s$ with $R b$ and $P$ with $A s$ ) have been performed to study and confirm the extreme conductive behavior in CDP and related substances, see e.g. [69], [75]-[79], but they will not be discussed here.

In the present work we investigate the relation between the vapor pressure of cesium dihydrogen phosphate and the electrical conductivity at elevated temperatures, up to and above the melting point. We report on the found conductivity properties of the superconducting phase and the liquid electrolyte, in a closed set-up in order to make sure that the solid and molten $\mathrm{CsH}_{2} \mathrm{PO}_{4}$ salt was intact during the measurements.

To our knowledge no one of the many earlier studies performed on the CDP salt, has focused on the protonic conduction properties in the solid state at temperatures above approximately $300^{\circ} \mathrm{C}$, the reason probably being connected with the extensive problems of dehydration of the electrolyte with an insufficient water pressure over the CDP. We also studied the reversibility of the shift between the monoclinic and the "superionic conduction phase" at around $\sim 230{ }^{\circ} \mathrm{C}$. The main objective of this work was thus to see if the conductivity of the salt would be preserved after longterm tempering while keeping the salt under its own vapor pressure in rather full ampoules. The magnitude of the vapor pressure was not known, so we set out starting to use our newly established method of determining water vapor pressures over corrosive chemicals versus temperature by use of Raman spectroscopy [80]. We have previously used this method to study the water vapor pressure over molten potassium dihydrogen phosphate $\left(\mathrm{KH}_{2} \mathrm{PO}_{4}\right)$ and determined the specific electrical conductivity, as well as demonstrated water electrolysis in the same system at $\sim 300{ }^{\circ} \mathrm{C}[5]-[6]$. 
In the present study, the temperature dependence of the vapor pressure above $\mathrm{CsH}_{2} \mathrm{PO}_{4}$ was found to be much higher than presumed in the literature. We measured the level of specific electrical conductivity of CDP under its own vapor pressure, below and above the phase transition, between the monoclinic conductive phase (II) and the highly conductive cubic one (I), and of the liquid electrolyte melt under its own vapor pressure. We wanted to study what happens over longer periods of time and to see if it occurs reversibly at even higher temperatures where very high water pressures are necessary to avoid decomposition of the CDP salt. Rapoport et al. [19] claimed no decomposition to occur even at $550^{\circ} \mathrm{C}$ and $20 \mathrm{kbar}$ in fast experiments, and noted that it should be showing how well pressure can stabilize the compound. To our knowledge the long time stability has not been studied before. We also wanted, with the help of DTG analysis, to redetermine the melting point temperature of CDP. The earlier given values vary between a widely reported value of $\sim 233^{\circ} \mathrm{C}$ and up to $\sim 346^{\circ} \mathrm{C}$, again as a result of the unnoticed dehydration decomposition at ambient water pressure and the associated formation of melting-pointdepression "impurities" [19], [36], [46]-[47], [81], as shown in the phase diagram in [55].

\section{Materials and Methods}

\subsection{Preparation of the salt}

Crystalline CDP, CAS \# 69089-35-6 is sensitive to conditions of preparation, as well as presence of micro-impurities and water. We prepared our samples, as described in most references, from $\mathrm{H}_{3} \mathrm{PO}_{4}$ (85 wt. \% solution, CAS \# 7664-38-2) and new $\mathrm{Cs}_{2} \mathrm{CO}_{3}$ (Cesium carbonate ReagentPlus ${ }^{\circledR}$, $99 \%$, CAS \# 534-17-8), both provided by Sigma Aldrich. $\mathrm{Cs}_{2} \mathrm{CO}_{3}$ was dissolved in Milli-Q ${ }^{\circledR}$ water and slowly mixed with the $\mathrm{H}_{3} \mathrm{PO}_{4}$ acid in a mol ratio of Cs:P $=1: 1$. The solution was concentrated by evaporation where after methanol (MeOH, puriss. P.a., ACS reagent, CAS 67-56-1, provided by Sigma Aldrich) was added to the solution to precipitate crude $\mathrm{CsH}_{2} \mathrm{PO}_{4}$. The yield was washed with methanol at least twice, since excess of $\mathrm{H}_{3} \mathrm{PO}_{4}$ dilutes in methanol $\left(\mathrm{H}_{3} \mathrm{PO}_{4}\right.$ is soluble and $\mathrm{CsH}_{2} \mathrm{PO}_{4}$ is not). The resulting solid was left to dry and thereafter heated to $90^{\circ} \mathrm{C}$ in a ventilated oven until the remaining water has evaporated. The formed crude $\mathrm{CsH}_{2} \mathrm{PO}_{4}$ was dissolved in Milli- ${ }^{\circledR}$ water and recrystallized in a petri dish at room temperature $\left(\sim 22^{\circ} \mathrm{C}\right)$ by slow evaporation in a ventilated hood for several days. After that the salt was kept at $90^{\circ} \mathrm{C}$ for one day to ensure complete dryness. The recrystallization ensured that residues of methanol, excessive acid or cesium solution which might have stayed between the crystallites were completely removed.

\subsection{Verification of the composition}

In order to verify the composition several portions with closely the same weight of recrystallized $\mathrm{CsH}_{2} \mathrm{PO}_{4}$ were weighed in platinum crucibles. These crucibles had previously been heated to red glowing in a flame and cooled in a desiccator filled with a Silica drying agent (CAS \# 112926-00-8, P-code 100897613, provided by Fluka Analytical) to ensure constant weight. The crucibles with the $\mathrm{CsH}_{2} \mathrm{PO}_{4}$ portions were placed in an electric oven, gently heated to and kept at $800{ }^{\circ} \mathrm{C}$ for 4 hours, then cooled down to $200{ }^{\circ} \mathrm{C}$ and immediately placed in the desiccator. After weighing the crucibles the $\mathrm{CsH}_{2} \mathrm{PO}_{4}$ to $\mathrm{CsPO}_{3}$ weight losses were compared. The solid residue average weight came out as $91.8 \pm 0.4 \mathrm{wt}$. \% of the initial compound, to be compared with the theoretical value $92.16 \mathrm{wt}$ \%. From this phosphate gravimetry our CDP is therefore considered to be $99.7 \pm 0.3 \%$ pure. It is important to verify the composition of the synthesized CDP, because an excess of 
phosphoric acid or $\mathrm{Cs}^{+}$ions could lead to formation of other compounds such as $\mathrm{CsH}_{5}\left(\mathrm{PO}_{4}\right)_{2}$ [34] [77], $\mathrm{Cs}_{8} \mathrm{P}_{8} \mathrm{O}_{24} \cdot 8 \mathrm{H}_{2} \mathrm{O}$ [81], and hydrates like $\mathrm{Cs}_{2} \mathrm{HPO}_{4} \cdot 2 \mathrm{H}_{2} \mathrm{O}$ [79] and $\mathrm{Cs}_{3} \mathrm{P}_{3} \mathrm{O}_{9} \cdot \mathrm{H}_{2} \mathrm{O}$ [82] which did not seem to have happened in our case.

\subsection{Measurements of the melting point}

The melting point of our pure CDP was determined from Differential Scanning Calorimmetry (DSC) analysis performed on hermetically sealed high-pressure sample crucibles of chrome nickel steel (AISI 316L) with similar lids both with gold-plated surfaces (product number 6.239.2-92.31.00) and reference containers. The crucible type was of bottom nominal width $6 \mathrm{~mm}$, with a volume of $27 \mu \mathrm{l}$, with maximum internal pressure of 100 bar and a maximum temperature of $500{ }^{\circ} \mathrm{C}$. After filling with about $22 \mathrm{mg}$ of salt, each crucible was closed with a sealing disk using a sealing press (product number 6.239.2-92.4), provided by the Netzsch Group. A Netzsch STA 409 PC (TG/DSC) instrument was used from room temperature to $\sim 500{ }^{\circ} \mathrm{C}$. A dry argon or air atmosphere was used, i.e. without humidification but the crucibles were quite full $(>30 \%)$. A constant heating rate of $1-2$ ${ }^{\circ} \mathrm{C} / \mathrm{min}$ was used.

\subsection{X-ray Powder Measurements}

X-ray diffraction on the recrystallized CDP powder was performed with the help of a Huber D670 diffractometer using the $\mathrm{Cu}-\mathrm{K}_{\alpha}$ radiation line $(\lambda=1.54056 \AA)$ in the range of $3^{\circ}$ to $100^{\circ}$ in steps of $0.02^{\circ}$ in $2 \theta$.

\subsection{Raman Vapor Pressure Measurements}

Our method to determine the vapor pressure of a substance contained in a sealed ampoule has recently been described in detail [6]. Note that precautions should be taken due to the risk of explosion whenever working with ampoules. The water vapor partial pressure at a given temperature is obtained by use of Raman spectrometry whereby the presence and identity of water molecules in the gas (the vapor constitution) is measured quantitatively. In spite of the weak scattering strength, Raman spectroscopy is a favorable method to determine the content of gases trapped in voids, because the signals are species-specific and the intensities normally are linearly dependent on concentration (in the absence of resonance [83]).

Sampling. Nitrogen and methane (>99.9\% pure gases) were obtained from AGA/Linde (Copenhagen S, Denmark). The Raman spectra showed no sign of trace impurities, confirming the gases to be clean and dry. The substance (here CDP) was placed in a home-made Pyrex ${ }^{\mathrm{TM}}$ ampoule $(\sim 2 \mathrm{~mm}$ wall thickness, $\sim 16 \mathrm{~mm}$ internal diameter) that via rubber tubing and a stem was connected to a vacuum line. The used ampoules were wide to avoid signals from the walls and round to better resist high internal pressures. After evacuation $(<0.1$ Torr) the ampoule was filled with reference gas (typically nitrogen or methane). The reference gas needs to be inert and to have a strong Raman signal. The gas was typically added up to a predetermined pressure ( 0.5 bar) that was read off on a calibrated Bourdon manometer at $\sim 22{ }^{\circ} \mathrm{C}$. Then the ampoule was sealed with a butane-oxygen torch flame. Enough $\mathrm{CsH}_{2} \mathrm{PO}_{4}$ was added to make the ampoule (cell) more than half full, so that minute changes in concentration by loss of water to the gas phase 
during later heating could be minimized. By comparing the quantitative Raman signals from the vapor and the reference gas, partial pressures can be determined, because the species-specific signals (intensity of reference and water) are linearly dependent on concentrations; by variation of the temperature the pressure as a function of temperature was obtained.

Methodology. The method requires knowledge (or determination) of the precise Raman scattering ratios between the sought gas substance (water) and the reference gas, respectively. The approximate concentration in $\mathrm{mol} \mathrm{L}^{-1}(\mathrm{n} / \mathrm{V})$ of the reference gas can be calculated with a reasonable accuracy using the ideal gas law, $n / V=p / R T$. Here $n$ is the number of moles, $V$ is the estimated ampoule volume $(\sim 6 \mathrm{~mL}), p$ is the partial pressure, $R$ is the gas constant $(0.083145 \mathrm{bar}$ $\times \mathrm{L} \times \mathrm{mol}^{-1} \times \mathrm{K}^{-1}$ ) and $T$ is the absolute Kelvin room temperature. After sealing, the reference gas concentration stays constant whereas the pressure of course increases with $T$.

The water molecule is an asymmetric top with $\mathrm{C}_{2 v}$ symmetry. It has a well-known Stokes Raman spectrum consisting of three active fundamental transitions: $v_{1}$ (symmetrical $\mathrm{O}-\mathrm{H}$ bond stretching), $v_{2}$ (symmetrical $\mathrm{H}-\mathrm{O}-\mathrm{H}$ angle bending), and $v_{3}$ (asymmetrical $\mathrm{O}-\mathrm{H}$ bond stretching) [94]-[99]. Infrared absorption $\left(v_{3}\right)$ of water is very intense but has the problem of strong absorption for common window materials so IR cannot be used. The $v_{1}$ band of water is relatively strong in Raman; the other ones are very weak. In the present case it means that the scattering ratios between the water $v_{1}$ band (symmetric $\mathrm{OH}$ stretching at $3655 \mathrm{~cm}^{-1}$ ) and the internal calibration gas reference (the $v_{1}$ vibrational Q-branch of $\mathrm{N}_{2}$ or $\mathrm{CH}_{4}$ ) can be used to sample the water pressure. The Q-branch corresponds to a vibrational transition with no change in the rotational state; i. e. the $J$ quantum number remains constant. These ratios have been previously found as $3.50 \pm 0.03$ for

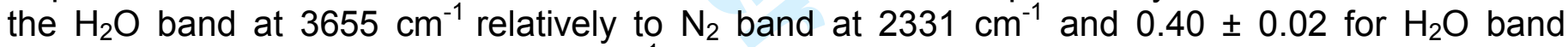
relative to the $\mathrm{CH}_{4}$ band at $2917 \mathrm{~cm}^{-1}$, respectively. The determinations were done on cells containing only water and nitrogen or methane in known amounts by measurements in our setup as explained in [6], [80]. The choice of nitrogen as internal inert reference calibration gas - unlike previously - has the risk of introducing errors due to nitrogen signals from the surrounding laboratory air, but the $\mathrm{N}_{2}$ signal problem was avoided by placing a laser line narrow band pass filter in front of the laser line just prior to the sample. $\mathrm{N}_{2}$ has the extra advantage that quartz ampoules can be used without risk of decomposition of the reference gas in the extreme heat needed for sealing silica. A more extensive description of the intensity calibration is given in [6], [80] and works cited there.

Measurements. Raman spectra were measured by use of a DILOR-XY $800 \mathrm{~mm}$ focal-length Czerny-Turner type spectrometer with $90^{\circ}$ macro entrance and a $10 \times 10 \mathrm{~cm}^{2} 1800$ lines $/ \mathrm{mm}$

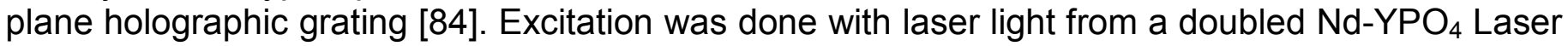
(wavelength $532 \mathrm{~nm} \mathrm{CW}$ vertically polarized at a power setting of up to $\sim 1.5 \mathrm{~W}$ ). The cells were placed vertically to let the light pass horizontally. Light was collected with a wide achromatic lens (10 $\mathrm{cm}$ focal length). Rayleigh scattering was removed with a holographic Notch filter. A quarter wave plate was mounted before the entrance slit to depolarize the light, making the grating efficiency independent of the polarization of the light. Slit widths and lengths were set to $600 \mu \mathrm{m}$ and $10 \mathrm{~mm}$ to obtain better signals at the expense of resolution [85]. The spectra were acquired with a multi-channel CCD detector (Horiba/Jobin-Yvon Synapse ${ }^{\mathrm{TM}}, 1024$ x 256 pixels) with thermoelectric cooling $\left(-69^{\circ} \mathrm{C}\right)$. The CCD signals were not calibrated for variation of the quantum efficiency versus wavelength. The gas spectral line intensities were measured $2-4$ times with automatic removal of cosmic spikes. Integration times were between 20 and $1200 \mathrm{~s}$, depending on 
the signal strength, and the excitation beam intensity was kept at $1.5 \mathrm{~W}$. The measurements were repeated and averaged in order to ensure reproducibility and obtain reliability. Measurements were done in a temperature range from $\sim 25^{\circ} \mathrm{C}$ to $\sim 400^{\circ} \mathrm{C}$; heating was achieved with a homemade insulated aluminum-bronze-core vertical-tube electrical furnace with four silica double layer windows [6], protected with a net of steel because of the risk of ampoule explosion. The gas or liquid/solid phase spectra were obtained by moving the ampoule holder up or down. Temperatures were determined with several 4-wire-Pt-100- $\Omega$ resistors to a precision better than $\sim 0.5{ }^{\circ} \mathrm{C}$ (the temperature inside the furnace was only precise to $\sim 2{ }^{\circ} \mathrm{C}$ due to gradients). The spectrometer $\mathrm{cm}^{-1}$ scale was calibrated with cyclohexane [86]. Other Raman experimental details (furnace, etc.) have been described elsewhere [87].

\subsection{Details of conductivity cells}

Four conductivity $\mathrm{H}$-shaped cells similar to the ones used recently [5] were fabricated to determine the conductivity $(\sigma)$ of the CDP substances. The cells were made from fused quartz glass by glass blowing. At first the bulb of a standard halogen lamp (PHILIPS type 7787XHP 36V/400W) was cut near the base and the tungsten spiral was cut over - thereby creating two electrodes for the first chamber. A similar operation was done for the second chamber. Details of the cell type and a picture can be found in a previous publication [5]. The tungsten electrodes were cleaned, etching off the $\mathrm{WO}_{3}$ (formed during the glass blowing) by means of $20 \mathrm{wt}$ \% aqueous HF overnight. Traces of $\mathrm{WO}_{3}$ were removed by filling the cell with an equimolar amount of $\mathrm{K}_{2} \mathrm{~S}_{2} \mathrm{O}_{7}$ and $\mathrm{K}_{2} \mathrm{SO}_{4}$, sealing under vacuum and heating to $440{ }^{\circ} \mathrm{C}$ in a rocking furnace (details are given previously [5] [84]) followed by rinsing the electrodes with water in an ultrasonic bath. Same cell was in some cases used for repeated experiments, after washing out all solidified salt with water under ultrasonic agitation, rinsing with ultrapure water (resistivity $=18 \mathrm{M} \Omega \mathrm{cm}$ ), drying it in a heating cabinet at $80^{\circ} \mathrm{C}$ and then adding new stems and new chemicals.

The cell constant $K$ for each cell was determined by measuring the resistance $R_{\mathrm{KCl}}$ for an aqueous $\mathrm{KCl}$ solution at a precisely known temperature near room temperature, according to the principles given by Jones and Bradshaw [88]. A standard solution was prepared following the ASTM Designation D1125-95 [89]: $3.734 \mathrm{~g}$ of high purity $\mathrm{KCl}$, prepared by us as earlier described [90] was dissolved in $502.11 \mathrm{~mL}$ at $22.0^{\circ} \mathrm{C}$ of Milli- $\mathrm{Q}^{\circledR}$ water to form a $0.1 \mathrm{D}$ solution of $\mathrm{KCl}$. The demal (D) unit is used for concentration in electrolytic conductivity primary standards and is equal to the molar concentration at $0{ }^{\circ} \mathrm{C}$; i.e. $0.1 \mathrm{D}$ represents 0.1 mole of $\mathrm{KCl}$ in one cubic decimeter of the solution at $0{ }^{\circ} \mathrm{C}$. The obtained $R_{\mathrm{KCl}}$ value should be dependent of the electrolyte concentration, the temperature and the dimensions of the narrow capillary tube between the chambers of the cell and independent of the electrode areas and total amount of $\mathrm{KCl}$ solution used.

\subsection{Conductivity measurement technique}

The resistance of each salt or melt was obtained from an $\mathrm{H}$-shaped cell, as described in our previous paper [5]. At first the materials that made up the sample were weighed and transferred quantitatively into the cell, which was sealed under vacuum $(<0.1$ Torr). Then the cell was heated and equilibrated in a rocking furnace, similar to one previously used [5]. Equilibration was performed at first at $\sim 350{ }^{\circ} \mathrm{C}$ (above the melting point) for several days. Temperatures for each data point were determined with 4 -wire-Pt-100- $\Omega$ resistors to a precision better than $\sim 0.5^{\circ} \mathrm{C}$. 
The impedance was measured with an automatic AC Wheatstone bridge potentiostat system (Princeton Applied Research VersaStat 4 with VersaStudio software) at an accuracy $\approx 0.1 \%$. The electrodes of the cell were connected to the potentiostat via shielded electric wires using the 2electrode input setup for the measurements (the pairs of chamber terminals were shorted in all the experiments as given: working electrode-sense electrode and counter electrode-reference electrode). The obtained impedance data were plotted as imaginary resistance versus real resistance curves for different frequencies of the applied alternating current supplied from the VersaStat 4 potentiostat. The resistance $R_{\text {sample }}$ was read off as the real abscissa from the lowest point on each impedance curve. This point is used to determine the $R_{\text {sample }}$ at the given temperature. Bubbles that might be present in the capillary and give a higher resistance were removed by rocking the furnace [5]. The conductivity of the sample (in units of $\mathrm{S} \mathrm{cm}^{-1}$ at the particular temperature) is calculated from the obtained resistance via the relation $\sigma_{\text {sample }}=$ $K / R_{\text {sample. }}$ The cell constant $K=R_{\mathrm{KCl}} \times \sigma_{\mathrm{KCl}}$ has previously been determined for each cell (filled with solution of $0.1 \mathrm{D} \mathrm{KCl}$ solution after the ASTM D1125 standard [89]). $K$ is rather independent of temperature because the fused quartz material hardly expands by heating, leaving the dimensions of the cell capillary rather unchanged (error less than $\sim 0.01 \%$ ). The reproducibility for measurements performed at the same temperature was within 0.5-1\%, after minimizing the tendency of bubble formation. In some experiments the cell constant was re-determined after finishing the measurements. Other experimental details have been described elsewhere [91], [92].

\subsection{Water Electrolysis Cell}

A home-constructed electrolysis cell was used similar to the previous one [6]. The cell was made by glass blowing from fused quartz glass tubing ( $14 \mathrm{~mm}$ O.D.) and a standard silica halogen lamp with vacuum-tight molybdenum-tungsten feed-throughs. Platinum electrodes were silverwelded to the internal feed-through tungsten spirals before more quartz tubes were added for later easy sealing. The cell was filled with CDP, attached to a vacuum line, evacuated, the $\mathrm{N}_{2}$ reference gas added, sealed, and mounted to the holder with electric cables (silver contact wires isolated by alumina beads) and heated in the Raman furnace (see figures in [6] for details). After connection to a Princeton Applied Research VersaStat 3 potentiostat the setup allowed electrolysis as well as successive recordings of Raman spectra of the melt and the gas phases at high temperatures (and pressures) by use of the furnace elevation system. Electrolysis went on for many minutes with currents of about 5 to $100 \mathrm{~mA}$. The furnace windows were covered with a protective steel net because of the risk of ampoule explosion [6].

\section{Results and Discussion}

\subsection{Differential Scanning Calorimetry analysis data.}

The behavior of $\mathrm{CsH}_{2} \mathrm{PO}_{4}$ upon heating under its own vapor pressure was studied by DSC in our hermetically sealed cells. A typical diagram is depicted in Figure 3. As expected two peaks were seen: A smaller peak at around $230{ }^{\circ} \mathrm{C}$, indicating the solid state II $\rightarrow$ I phase transition in the CDP salt, as previously reported in e.g. [8], [21], [35], [38], [47], [49]-[50], [56], and a larger peak at around $345^{\circ} \mathrm{C}$, being the melting point signal. As noticed above previous thermal analysis results for $\mathrm{CsH}_{2} \mathrm{PO}_{4}$ varied, but for sealed and fully contained experiments most experimentalists have 
agreed on results similar to what was found in this work. From the overview over already published DSC data it is evident that the behavior depends somewhat on the heating rate, and different results were found for e.g. $8.5{ }^{\circ} \mathrm{C} / \mathrm{min}$ [93] and $2.5{ }^{\circ} \mathrm{C} / \mathrm{min}$ [51] in open or closed crucibles. The dependence on heating rate, amount of humidity and enclosure is explained by the fact that equilibrium had not been achieved, and water was escaping from the salt at different speeds during the experiments. This is why we decided to perform the following vapor pressure and conductivity measurements with salts at pressurized conditions, placed in closed ampoules that were able to maintain the considerable water vapor pressures over the salts.

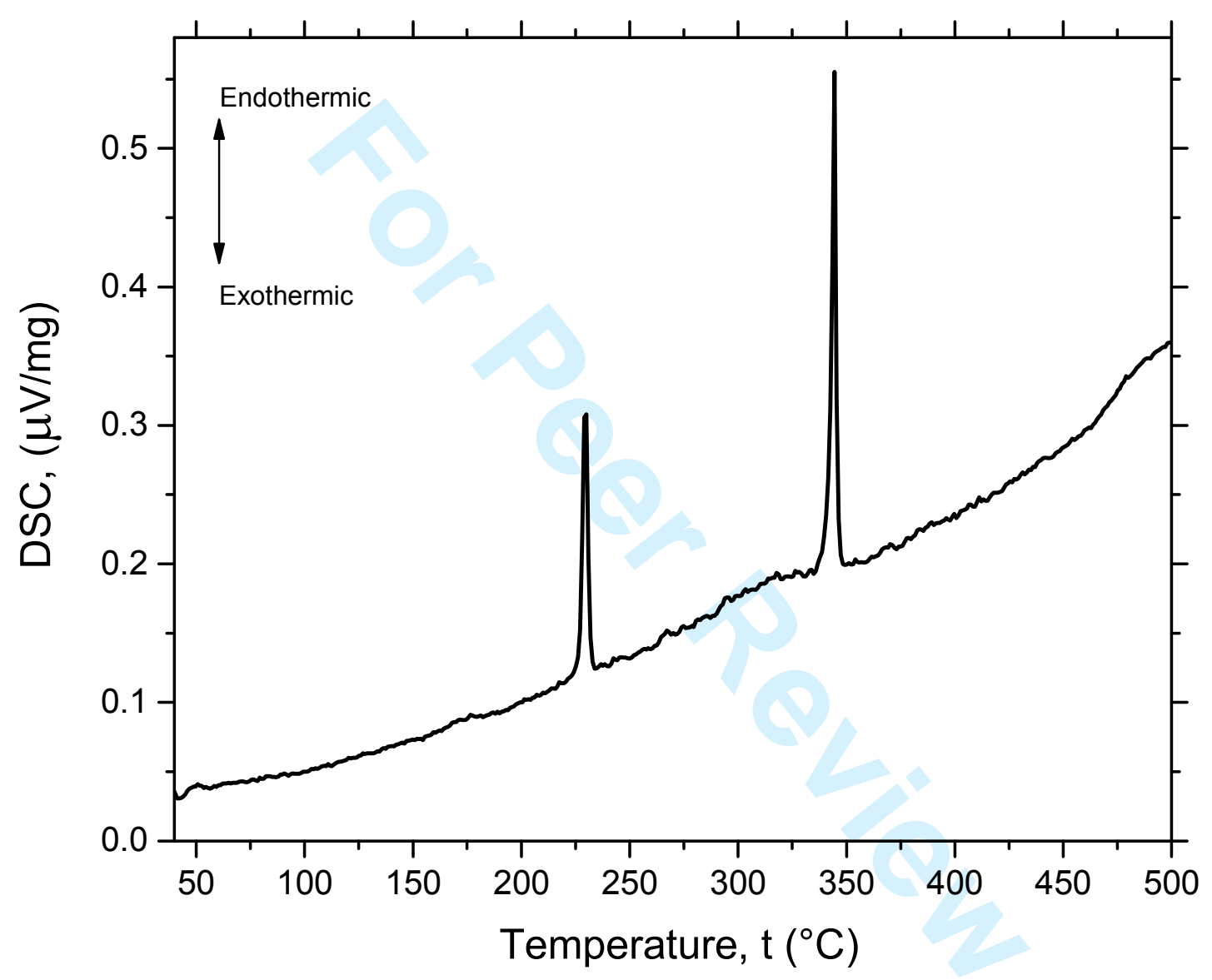

Figure 3. Differential Scanning Calorimetry plot for pure $\mathrm{CsH}_{2} \mathrm{PO}_{4}$ in a hermetically closed goldplated crucible containing $22 \mathrm{mg}$ of the compound in air. Heating rate $1{ }^{\circ} \mathrm{C} / \mathrm{min}$.

\subsection{X-ray powder diffraction data.}

X-ray powder diffraction data were obtained for our synthesized $\mathrm{CsH}_{2} \mathrm{PO}_{4}$ as shown in Figure 4. The results are given together with data on CDP from the ICSD crystallographic database, FIZ Karlsruhe in Germany, compound no. 200895. From this comparison it can be seen that there is a very good agreement between our data and the data by Matsunaga et al. [66], characterizing the identity of our material. The differences in intensity were probably caused by preferred orientation in the powder. 


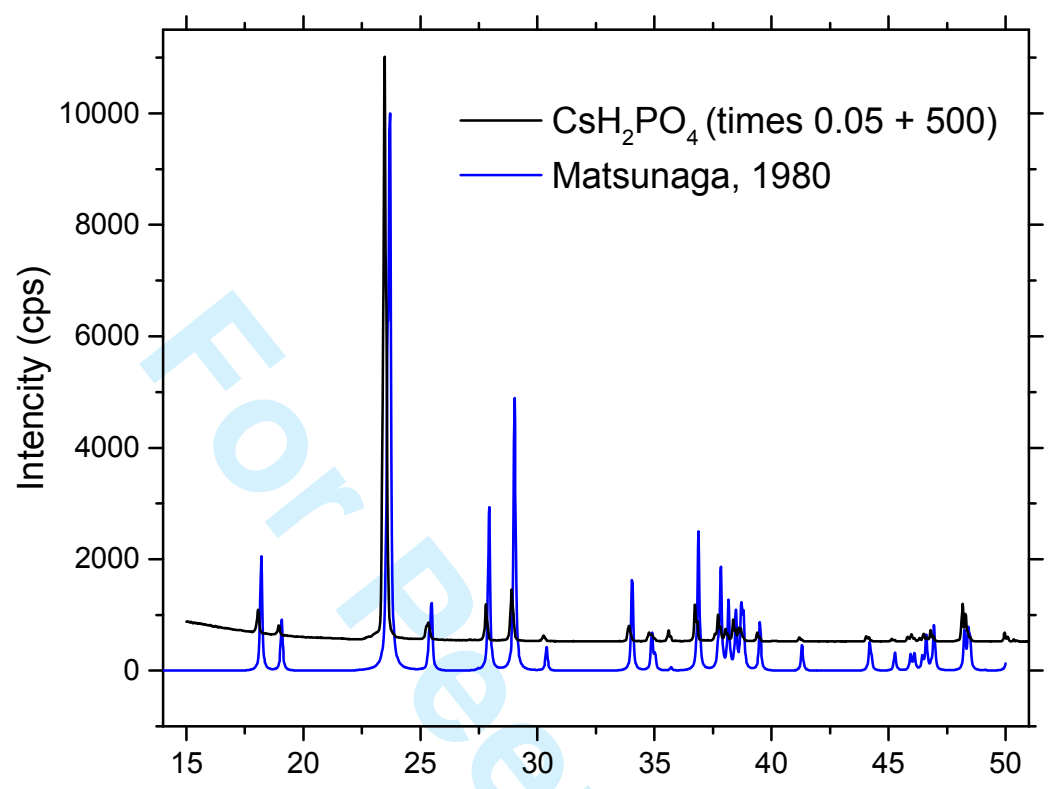

Figure 4. X-ray powder diffraction data on $\mathrm{CsH}_{2} \mathrm{PO}_{4}\left(\mathrm{Cu}-\mathrm{K}_{\alpha}\right.$ radiation, $\lambda=1.54056 \AA$ ). Black curve: Result of our synthesized CDP. Blue curve: Calculated diagram for $\mathrm{P} 2{ }_{1} / \mathrm{m}$ CDP phase II at room temperature, obtained by use of the "CCDC Mercury program" from www.ccdc.cam.ac.uk, based on single crystal data from the ICSD (Inorganic Crystal Structure Database) FIZ Karlsruhe, compound no. 200895 (originally published by Matsunaga et. al. [66]).

\subsection{Raman spectroscopic measurements}

Vapor pressure determination. The Raman spectra of the water vapor above CDP were recorded versus temperature for a number of more than half full sealed tube cells. The gas phase spectra have been recorded several times after equilibration for several hours at temperatures from $\sim 25$ to $\sim 350{ }^{\circ} \mathrm{C}$ for each cell. Methane or nitrogen has been added as internal calibration standards. Typical spectra are shown in Figure 5. The areas of the peaks were determined as indicated. In spite of the rather weak scattering strength, the Raman technique can determine the gas content in the cells, because the signal is species-specific and the intensity depends on the concentration at a rate determined by the known scattering cross section ratios for the molecules, here $\mathrm{H}_{2} \mathrm{O}$ to $\mathrm{CH}_{4}$ or $\mathrm{H}_{2} \mathrm{O}$ to $\mathrm{N}_{2}$. The spectra contain the well-known Q-branch rot-vib bands of the added nitrogen or methane (the $v$ str bands of $\mathrm{N}_{2}$ at $\sim 2331 \mathrm{~cm}^{-1}$ [100] or the $v_{1}\left(\mathrm{~A}_{1}\right)$ sym str band of $\mathrm{CH}_{4}$ at $2917 \mathrm{~cm}^{-1}$ [101]) in addition to the $Q$ branch rot-vib of the water molecules originating from the salt (the $v_{1}$ sym str band of $\mathrm{H}_{2} \mathrm{O}$ at $\sim 3655 \mathrm{~cm}^{-1}$ ). The water band at $\sim 3655 \mathrm{~cm}^{-1}$, see Figure 5 , looks 
like the $\mathrm{H}_{2} \mathrm{O}$ spectra in the literature, see e.g. [94]-[99]. The relatively high pressures and temperatures broaden the bands by populating higher rotation-vibration (rot-vib) levels so that most spectral details remain unresolved, as discussed in detail in [6], [80].

The areas of the bands for several acquisitions (two or more sets of spectra) were integrated with use of the Labspec software. For the nitrogen or methane band envelopes, the areas were taken to range from $\sim 2310$ to $\sim 2345 \mathrm{~cm}^{-1}\left(S_{\mathrm{N} 2}\right)$ or from $\sim 2895$ to $\sim 2935 \mathrm{~cm}^{-1}\left(S_{\mathrm{CH} 4}\right)$, respectively, and for the water band the area was set to range from $\sim 3610$ to $\sim 3676 \mathrm{~cm}^{-1}\left(S_{\mathrm{H} 2 \mathrm{O}}\right)$, as indicated in Figure 5 . The water pressure was then calculated in the following way: By knowing e. g. the nitrogen pressure $p^{\circ}{ }_{N 2}$ at the ambient Kelvin temperature $T_{o}$, the water pressure $p_{\mathrm{H} 2 \mathrm{O}}$ at the actual experiment temperature $T$ is given approximately by the ideal gas law as (eq. (3)):

$$
p_{\mathrm{H} 2 \mathrm{O}}=p_{\mathrm{N} 2}^{o} \times\left(T \times S_{\mathrm{H} 2 \mathrm{O}} \times \sigma_{\mathrm{N} 2}\right) /\left(T_{\mathrm{O}} \times S_{\mathrm{N} 2} \times \sigma_{\mathrm{H} 2}\right) .
$$

$S$ denotes the integrated Raman band signal area above the background for the molecules in play, here nitrogen and water. Similarly in the case of methane as the reference, the water pressure $p_{\mathrm{H} 2 \mathrm{O}}$ is given by eq. (4):

$$
p^{o}{ }_{\mathrm{CH} 4}=p^{\circ}{ }_{\mathrm{CH} 4} \times\left(T \times S_{\mathrm{H} 2 \mathrm{O}} \times \sigma_{\mathrm{CH} 4}\right) /\left(T_{\mathrm{O}} \times S_{\mathrm{CH} 4} \times \sigma_{\mathrm{H} 2 \mathrm{O}}\right) .
$$

The scattering cross section ratios, $\sigma_{\mathrm{H} 2 \mathrm{O}} / \sigma_{\mathrm{N} 2}$ or $\sigma_{\mathrm{H} 2 \mathrm{O}} / \sigma_{\mathrm{CH} 4}$ between water and nitrogen or water and methane gas molecule Q-branch areas, as defined above, respectively, take values at around $\sim 3.50$ or $\sim 0.40$, respectively, as determined previously [80], rather independently of temperature [94], although some deviations from these values were seen in older literature.

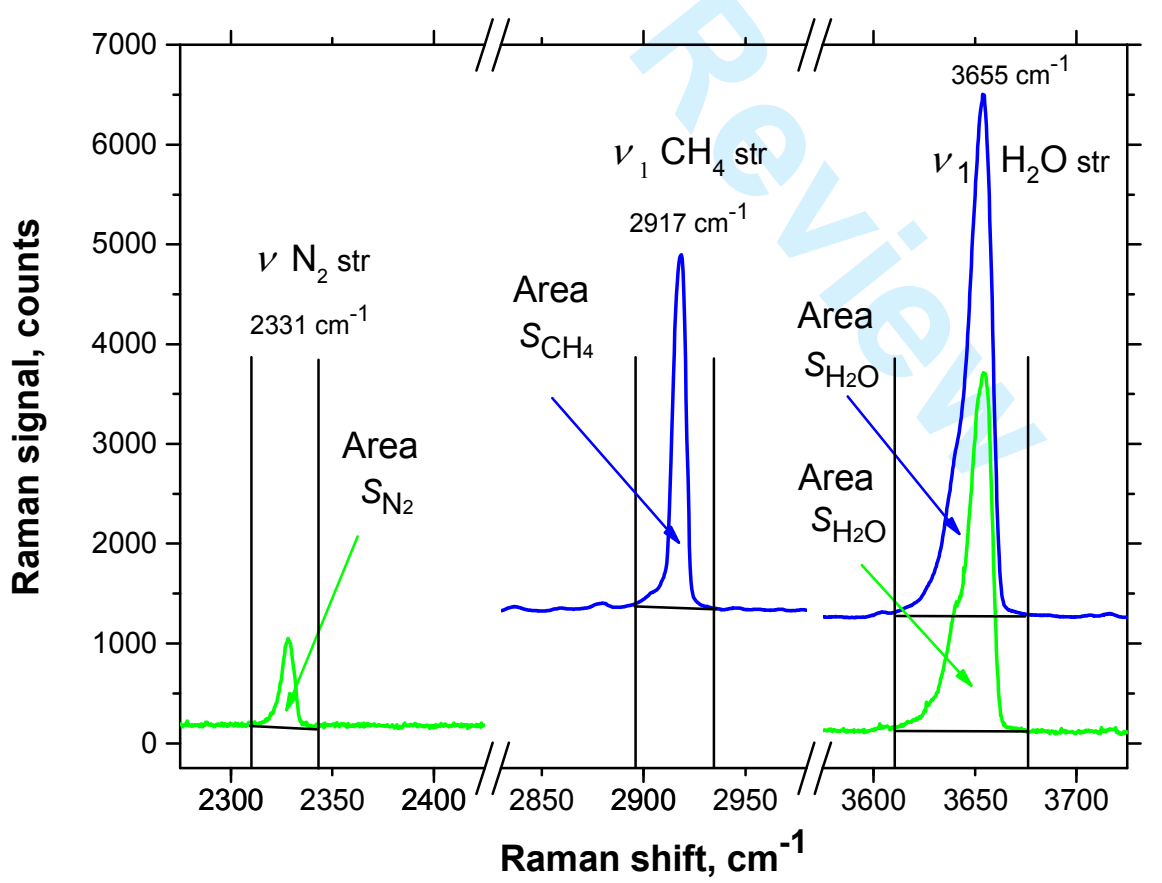

Figure 5. Typical spectra illustrating the principle of Raman spectroscopic quantitative determination of water (to the right) in sealed ampoules with nitrogen (to the left) or methane (in the middle) as reference gasses. The spectra were recorded with a $532 \mathrm{~nm}$ green laser under carefully experimental settings of the spectrometer to let accurate band areas, $S_{\text {water }}$ and $S_{\text {reference }}$ 
be determined. The used integration ranges were from $\sim 2310$ to $\sim 2345\left(\mathrm{~N}_{2}\right)$, from $\sim 2895$ to $\sim 2935$ $\left(\mathrm{CH}_{4}\right)$, and from $\sim 3610$ to $\sim 3676 \mathrm{~cm}^{-1}\left(\mathrm{H}_{2} \mathrm{O}\right)$. This allowed values for the ratio between the area $\left(S_{\mathrm{H} 20}\right)$ of the water band relative to the reference area $\left(S_{\mathrm{N} 2}\right.$ or $\left.S_{\mathrm{CH} 4}\right)$ to be calculated. From this the water pressure was calculated as explained in the text.

A summary of the water vapor pressure results for five $\mathrm{CsH}_{2} \mathrm{PO}_{4}$ sealed Raman cells, quantified by $\mathrm{CH}_{4}$ or $\mathrm{N}_{2}$ intensity calibrations, are given numerically in Table 1 and shown graphically in Figure 6.

It is clear from Figure 6 that very similar results are obtained independent of whether nitrogen or methane are used as references for the pressure measurement. This indicates that the Raman spectroscopy pressure measurement technique is likely to be correct. A similar conclusion was reached when we studied the vapor pressure over concentrated phosphoric acid [80].

It is seen that the vapor pressure of CDP is much lower than for water at a given temperature; see the known vapor pressure curve of steam from the NIST Standard Reference Database [102] that is also included in Figure 6. The low CDP vapor pressure is to be understood as a high affinity for water to stay in the melt; it is being bound by strong hydrogen bonds.

On the other hand the CDP vapor pressure in general is much higher than what has been claimed in the literature, based on different indirect methods, see e.g. [4], [12], [21], [27], [46], [55], [103]. The formula reproduced as equation (2) has been claimed to be valid up to perhaps $315{ }^{\circ} \mathrm{C}$ (according to Taninouchi et al. [46], [55]). When this formula was plotted with the A and B constants [46], [55] we obtained the two curves also included in Figure 6. It is clear that our measurements correspond to higher pressures. It indicates - to our belief - that it takes time for CDP to reach the equilibrium, presumably several hours in some cases. This might explain why literature values were found too low.

Also included in Figure 6 are the results from an experiment we made with a pressure cell with $\mathrm{CsH}_{2} \mathrm{PO}_{4}: \mathrm{CsPO}_{3}$ equal to $50 \mathrm{~mol} \%: 50 \mathrm{~mol} \%$. The actual composition of the liquid phase in the 50 $\mathrm{mol} \%$ : $50 \mathrm{~mol} \%$ experiment is "not known precisely" because visual inspection showed that it is saturated with a solid (probably $\mathrm{CsPO}_{3}$ ). The solubility of $\mathrm{CsPO}_{3}$ is expected to be low and to vary with the temperature. It is interesting that the $50 \mathrm{~mol} \%: 50 \mathrm{~mol} \%$ curve is following about the same path as the curves of Taninouchi et al. [46], [55]: This might indicate that their samples have lost substantial amounts of water, or their extrapolation procedure has been based on assumptions that are not entirely valid, e.g. such as lack of equilibrium. 
Table 1. Vapor Pressure Data from ampoules with pure $\mathrm{CsH}_{2} \mathrm{PO}_{4}$, an electrolysis cell and a cell with $\mathrm{CsH}_{2} \mathrm{PO}_{4}: \mathrm{CsPO}_{3}=50 \%$ mol: $50 \%$ mol (presumably $\mathrm{CsH}_{2} \mathrm{PO}_{4}$ saturated with $\mathrm{CsPO}_{3}$ at the temperature).

\begin{tabular}{|c|c|c|c|c|c|c|c|}
\hline \multicolumn{2}{|c|}{$\mathrm{CDP}, \mathrm{CH}_{4}$ reference } & \multicolumn{2}{|c|}{$\mathrm{CDP}, \mathrm{N}_{2}$ reference } & \multicolumn{2}{|c|}{$\mathrm{CDP}, \mathrm{N}_{2}$ reference } & \multicolumn{2}{|c|}{$\mathrm{CDP}, \mathrm{N}_{2}$ reference } \\
\hline Temp. ${ }^{\circ} \mathrm{C}$ & Pres. bar & $\begin{array}{l}\text { Temp. } \\
{ }^{\circ} \mathrm{C}\end{array}$ & Pres. bar & Temp. ${ }^{\circ} \mathrm{C}$ & Pres. bar & Temp. ${ }^{\circ} \mathrm{C}$ & Pres. bar \\
\hline 25 & 0.0100 & 24 & 0.0062 & 24 & 0.0014 & 24 & 0.0068 \\
\hline 99 & 0.1533 & 24 & 0.0072 & 24 & 0.0026 & 124 & 0.6482 \\
\hline 101 & 0.1882 & 24 & 0.0054 & 150 & 0.7028 & 124 & 0.6155 \\
\hline 175 & 0.8569 & 100 & 0.2880 & 150 & 0.8602 & 183 & 1.2211 \\
\hline 175 & 1.0527 & 100 & 0.2411 & 200 & 1.1407 & 183 & 1.1289 \\
\hline 225 & 2.2045 & 100 & 0.2645 & 200 & 1.1635 & 237.5 & 2.1783 \\
\hline 225 & 1.4294 & 150 & 0.6427 & 225 & 1.5826 & 237.5 & 2.2189 \\
\hline 225 & 1.8705 & 150 & 0.6358 & 225 & 1.4546 & 237.5 & 2.0577 \\
\hline 250 & 2.2912 & 200 & 0.8236 & 225 & 1.4498 & 237.5 & 2.2717 \\
\hline 250 & 2.2199 & 200 & 0.8316 & 250 & 2.2021 & 270 & 4.6286 \\
\hline 250 & 2.3986 & 250 & 1.1917 & 250 & 2.2324 & 270 & 4.6820 \\
\hline 300 & 10.5552 & 250 & 1.2413 & 250 & 2.2139 & 285 & 7.7666 \\
\hline 300 & 10.1799 & 300 & 10.9211 & 275 & 5.3919 & 285 & 7.9473 \\
\hline 324 & 17.9230 & 300 & 11.2687 & 275 & 5.2307 & 295 & 9.4607 \\
\hline 325 & 18.8111 & 325 & 15.9085 & 275 & 6.6650 & 295 & 9.9002 \\
\hline \multirow[t]{4}{*}{326} & 18.0191 & 325 & 17.0292 & 275 & 5.9115 & 305 & 12.3005 \\
\hline & & 336 & 12.1081 & 275 & 5.8104 & 305 & 12.0803 \\
\hline & & 336 & 10.8433 & 300 & 9.1097 & 305 & 11.7479 \\
\hline & & 340 & 11.2125 & 310 & 13.2037 & 315 & 13.8865 \\
\hline \multicolumn{2}{|c|}{$\mathrm{CDP}-\mathrm{CsPO}_{3}, \mathrm{~N}_{2}$ reference } & 340 & 11.9260 & 310 & 13.6678 & 315 & 13.0463 \\
\hline 25 & 0 & & & 310 & 13.6326 & 325 & 17.0387 \\
\hline 310 & 0.7738 & & & 320 & 16.2841 & 325 & 16.4465 \\
\hline 311 & 1.1122 & \multicolumn{2}{|c|}{ CDP electrolysis cell, } & 320 & 16.9711 & 330 & 17.3501 \\
\hline 388 & 5.5946 & \multicolumn{2}{|c|}{$\mathrm{N}_{2}$ reference } & 320 & 16.2551 & 330 & 16.6891 \\
\hline 392 & 5.6259 & 355 & 23.015 & 325 & 18.5595 & 330 & 19.1948 \\
\hline 400 & 7.2452 & & & 325 & 15.8813 & 330 & 15.4824 \\
\hline 410 & 8.8089 & & & 330 & 14.4820 & 335 & 18.5185 \\
\hline 410 & 9.0636 & & & & & 335 & 19.2922 \\
\hline
\end{tabular}




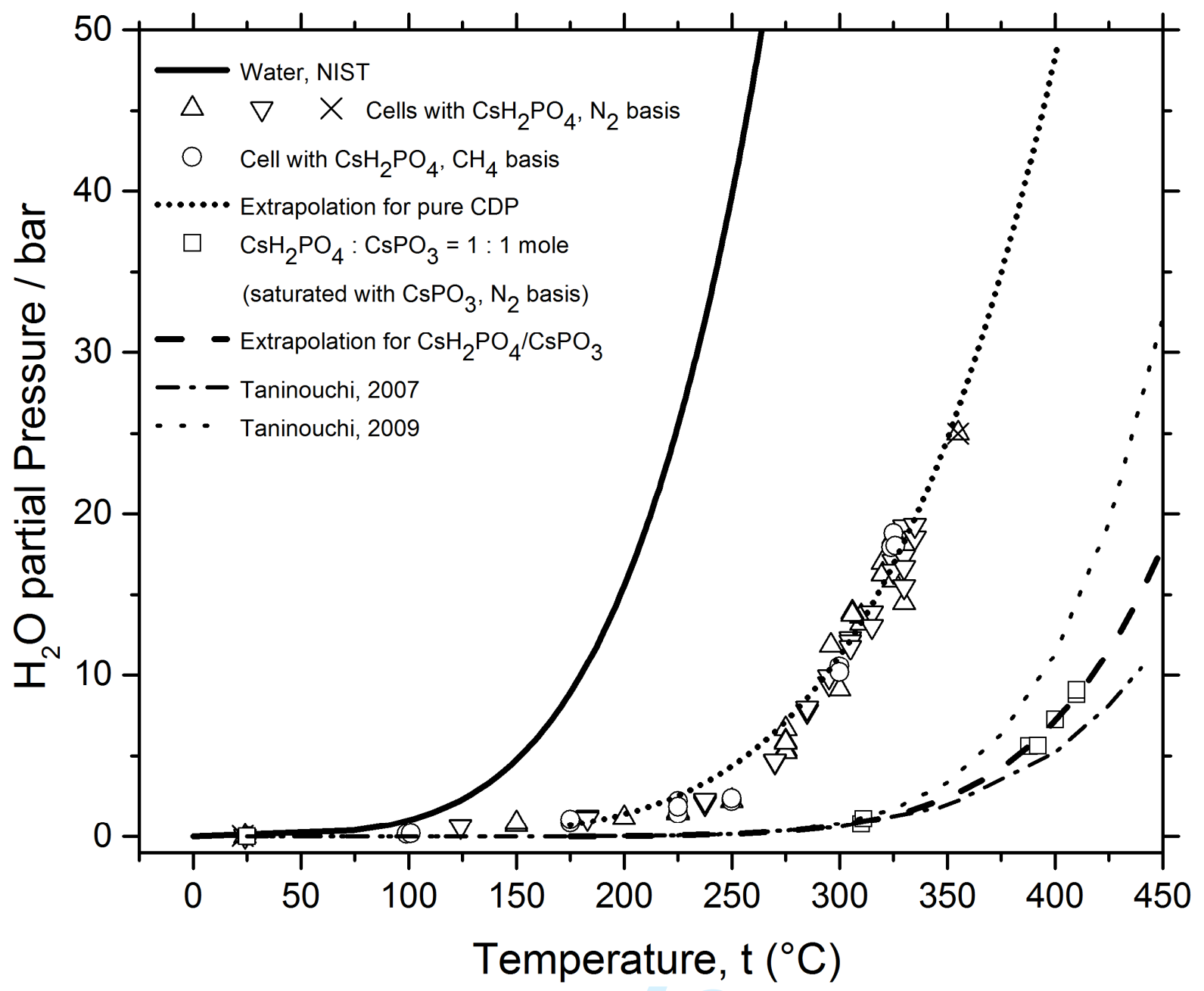

Figure 6. Vapor pressures in sealed ampules versus temperature. The points represent our measurements. The curves show the standard vapor pressures of water from NIST [102] (full curve) compared with $\mathrm{CsH}_{2} \mathrm{PO}_{4}$ (narrow dotted) and $\mathrm{CsH}_{2} \mathrm{PO}_{4}: \mathrm{CsPO}_{3}, 50 \%: 50 \%$ by $\mathrm{mol} \%$ (dashed, probably $\mathrm{CsH}_{2} \mathrm{PO}_{4}$ saturated with $\mathrm{CsPO}_{3}$ at the temperature) as obtained by us. The establishment of equilibrium took several hours; if measurements were taken immediately after a stable temperature was reached, non-equilibrium lower results were obtained. Two curves of "partial pressure of water, $\mathrm{pH}_{2} \mathrm{O} / \mathrm{atm}$," obtained via an extrapolation procedure by Taninouchi et al. [46], [55] are also given. Their latest determined wide dotted curve [55] is presumably better determined than their first dash-dotted one [46].

The narrow dotted and dashed curves for CDP and the $\mathrm{CsPO}_{3}$ saturated mixture were calculated from the experimental points in Table 1 by using a linear fitting procedure on $\log _{10} p$ (in bar) plotted against $1000 / \mathrm{T}$, in the range $250-353^{\circ} \mathrm{C}$ for the pure CDP data, and in the range $310-410$ ${ }^{\circ} \mathrm{C}$ for the $1 / 1$ molar mixture of $\mathrm{CsH}_{2} \mathrm{PO}_{4} / \mathrm{CsPO}_{3}$ melt. The parameters for the fitted curves are presented in Figure 7. 


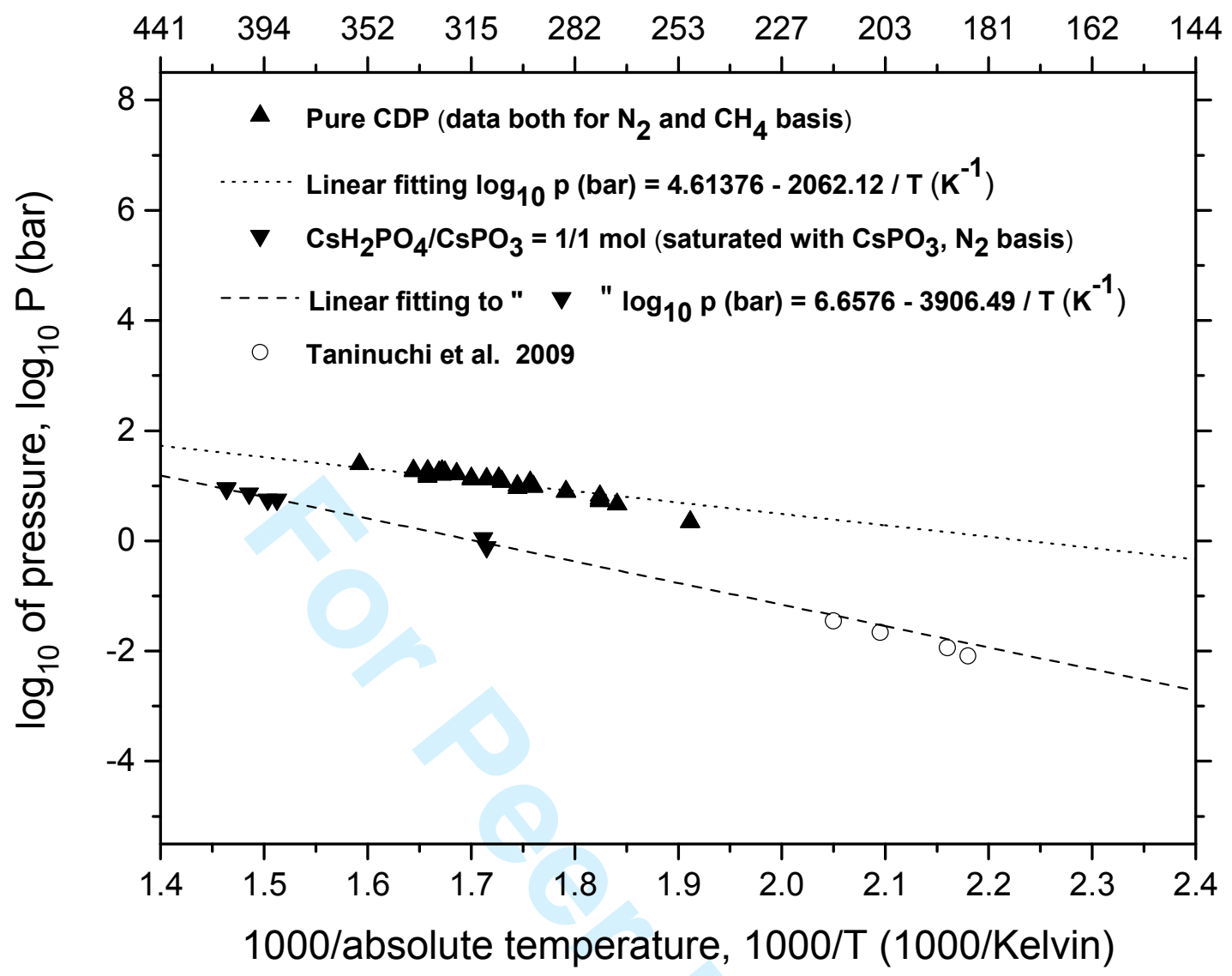

Figure 7. Logarithmic fitting for data on the vapor pressure over pure CDP and for $\mathrm{CsH}_{2} \mathrm{PO}_{4} / \mathrm{CsPO}_{3} 1 / 1$ molar mixture (presumably saturated with $\mathrm{CsPO}_{3}$ at the temparature). Also shown are circular points from Taninouchi et al. [55].

Raman on CDP versus temperature. We studied Raman spectra of the CDP substance versus temperature in the cells used for the vapor pressure measurements and got results as summarized in Figure 8. Similar spectra at low temperatures and up to $\sim 250{ }^{\circ} \mathrm{C}$ have already been obtained and much discussed in the literature [4], [25], [37], [70], [104]-[110]. Our Raman spectra looked much like the previous published spectra of confined CDP (large crystals, pellets or samples in sealed glass cells) at various temperatures. Typical CDP spectra can be seen in e.g. Figure 5(a) of reference [4], showing the spectral shifts and linewidth broadening of the internal modes versus temperature up to $\sim 260{ }^{\circ} \mathrm{C}$. As a new result, it was possible for us to record the spectrum of the melt and to observe a new line at $\sim 700 \mathrm{~cm}^{-1}$ originating from the formation of pyrophosphate ions (with P-O-P bridges), starting at temperatures higher than about $310^{\circ} \mathrm{C}$. Such a spectral line, at $\sim 710 \mathrm{~cm}^{-1}$, has analogously been found when $\mathrm{KH}_{2} \mathrm{PO}_{4}$ was heated at high temperatures $\left(\sim 325^{\circ} \mathrm{C}\right)$ in closed cells [6]. Also a similar line was found and well documented for polycrystalline $\mathrm{Na}_{2} \mathrm{H}_{2} \mathrm{P}_{2} \mathrm{O}_{7}$ at room temperature [70] but it was not present in $\mathrm{NaH}_{2} \mathrm{PO}_{4}$ [111]. 


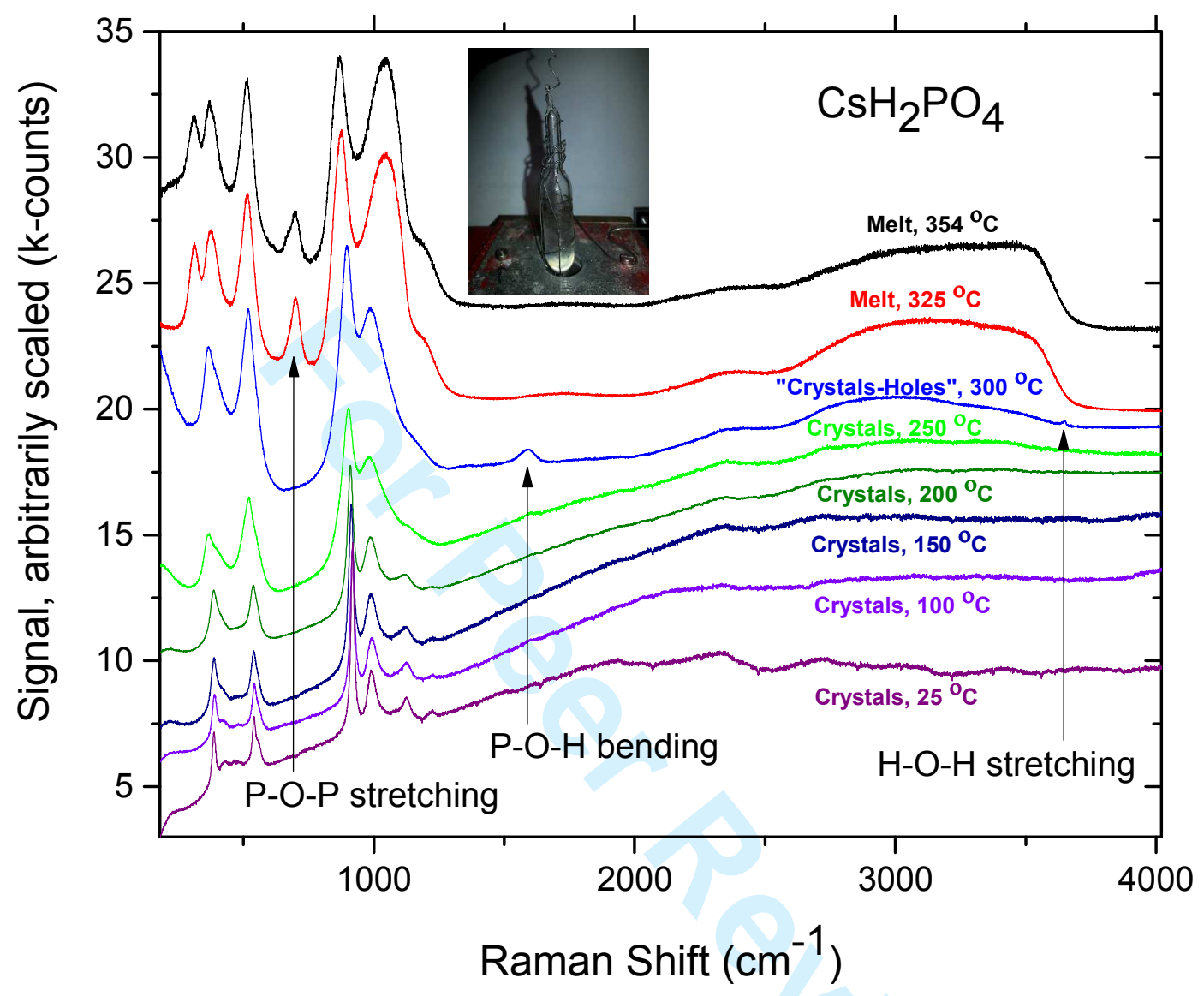

Figure 8. Raman spectra of $\mathrm{CsH}_{2} \mathrm{PO}_{4}$ in sealed cells, as crystal powder and as molten electrolyte versus temperature. The inserted photo shows a cell just taken out of the furnace and with still molten CDP starting to freeze from the bottom. Up to about $300{ }^{\circ} \mathrm{C}$ the samples looked like powders. At higher temperatures the content looked like ice containing gas filled holes. Spectra with indications of indication of $\mathrm{P}-\mathrm{O}-\mathrm{H}$ bending and single water molecules were obtained in some instances (blue spectrum with a $\mathrm{H}-\mathrm{O}-\mathrm{H}$ stretching band at $\sim 3655 \mathrm{~cm}^{-1}$, compare with Figure 5). was seen (at $\sim 1590 \mathrm{~cm}^{-1}$ ). The melts showed broad features from $\sim 2300$ to $\sim 3600 \mathrm{~cm}^{-1}$ that are characteristic of P-O-H stretching. Spectral bands below $\sim 1500 \mathrm{~cm}^{-1}$ are due to the phosphate ions. Polyphosphate ions giving rise to bands at around $700 \mathrm{~cm}^{-1}$ (P-O-P bridge stretching) are seen in the molten transparent mixtures when the temperature was high enough $\left(\sim 325^{\circ} \mathrm{C}\right)$. The pressure was dangerously high inside the cells and explosions occurred. 
The superionic plastic phase of CDP contains characteristic broad bands because of the phase disorder with rapid reorientation of the $\mathrm{H}_{2} \mathrm{PO}_{4}^{-}$and $\mathrm{O}-\mathrm{H}^{-}$anions, involving breaking of some hydrogen bonds $(\mathrm{P}-\mathrm{O} \cdots \cdot \mathrm{H}-\mathrm{O}-\mathrm{P})$ and creating other ones and thus causing the Raman bands to be broad [53], [70]. The high temperature line-broadening of CDP was first reported by Romain and Novak [70]. By virtue of the intensive broad band envelope from $\sim 2300$ to $\sim 3600 \mathrm{~cm}^{-1}$ the spectra also indicate a considerable amount of water bound in the melt, even at high temperatures. The salt apparently has a "thirst" against water. The broad envelope band at $\sim 2000$ to $\sim 3600 \mathrm{~cm}^{-1}$ is due to the dynamically disordered hydrogen bond network like in the CDP cubic phase. This structure is thought to be responsible for the high proton conductivity and for the high affinity between the salt and the water. When quenching the melt large crystals resulted, but the quartz or Pyrex glass also tended to develop cracks and to explode. The solid crystals had spectra similar to original CDP and no water soon remained in the gas phase. The easy and fast crystallization means that the water already is much available inside the CDP liquid at high temperature and moving quickly around (superconductivity) because otherwise there would not be time for the observed formation of coarsely grained crystals.

\subsection{Conductivity measurements}

We determined the conductivity of $\mathrm{CsH}_{2} \mathrm{PO}_{4}$ at higher temperatures than previously. An experimental series was made with four conductivity cells: One filled with pure CDP and also cells containing CDP with more and less water (a mixture of CDP and frozen $\mathrm{H}_{2} \mathrm{O}$ and two mixtures of $\mathrm{CsH}_{2} \mathrm{PO}_{4}$ and $\mathrm{CsPO}_{3}$ ). The compositions are given in Table 2. After adding the chemicals to the cells and sealing under vacuum the compositions are known at room temperature. But after heating to higher temperatures various amounts of water are taken up by the solid or lost to the gas phase. The composition of the condensed phases must depend on the amount of water in the gas phase and thus on the temperature. It means that compositions in principle should be corrected at each temperature. Approximate corrected compositions were estimated by use of the ideal gas law.

As an example for cell 1 (pure CDP at e.g. $300{ }^{\circ} \mathrm{C}, 573 \mathrm{~K}$ ), the pressure $p$ of water over the salt was approximately 11.2 bar, estimated by use of the results in Figure 6 . The volume $V$ was about $12.4 \mathrm{~mL}$, and we can thus estimate how much water $(n \mathrm{~mol})$ should be lost to the gas phase: $n=$ $p V / R T=(11.3 \times 0.0124) /(0.083 \times 573)$ mol. This amount of water must be subtracted from the CDP amount and added to the $\mathrm{CsPO}_{3}$ amount to calculate the corrected composition.

The formal composition is conveniently given as the molar composition ratio $\left(\mathrm{CsPO}_{3} / \mathrm{H}_{2} \mathrm{O}\right)$ of added amounts. Thus a molar ratio of 1 would correspond to pure $\mathrm{CsH}_{2} \mathrm{PO}_{4}$. A ratio of 2 would be $\mathrm{CsH}_{2} \mathrm{PO}_{4}+\mathrm{CsPO}_{3}$ (a molar ratio of $1 \mathrm{CsH}_{2} \mathrm{PO}_{4}$ to $1 \mathrm{CsPO}_{3}$ ) and so on. For other compositions, the ratio was lower or higher than 1 depending on addition of water or $\mathrm{CsPO}_{3}$ to the cell, respectively, according to Equation 1.

The steam partial pressures in the cells 1 and 4 were determined from Figure 6 directly, but for cells 2 and 3 the gas pressures needed to be determined by extrapolation / interpolation, see Table 2 and Figure 9. 
Table 2. Compositions of the $\mathrm{CsH}_{2} \mathrm{PO}_{4}-\mathrm{CsPO}_{3}-\mathrm{H}_{2} \mathrm{O}$ salt mixtures in the four conductivity experiments, given formally (total mass added) and with account for evaporated amounts of water at 300 and $400{ }^{\circ} \mathrm{C}$ at equilibrium in accordance with Equation (1).

\begin{tabular}{|c|c|c|c|c|c|c|c|c|c|c|c|}
\hline \multirow{3}{*}{$\begin{array}{c}\text { Cell } \\
\text { numb } \\
\text { er }\end{array}$} & \multirow{3}{*}{$\begin{array}{l}\text { Mass } \\
\text { of } \\
\text { added } \\
\text { CDP, } \\
\text { g }\end{array}$} & \multirow{3}{*}{$\begin{array}{l}\text { Mass } \\
\text { of } \\
\text { added } \\
\mathrm{CsPO}_{3} \\
\text { or } \\
\mathrm{H}_{2} \mathrm{O}, \mathrm{g}\end{array}$} & \multirow{3}{*}{$\begin{array}{c}\text { Formal } \\
\text { composi } \\
\text { tion } \\
\text { ratio } \\
\mathrm{CsPO}_{3} / \\
\mathrm{H}_{2} \mathrm{O} \\
\text { at } 25^{\circ} \mathrm{C}\end{array}$} & \multirow{2}{*}{\multicolumn{2}{|c|}{$\begin{array}{l}\text { Estimated }{ }^{a} \\
\text { gas } \\
\text { pressure in } \\
\text { cells, bar }\end{array}$}} & \multirow{2}{*}{\multicolumn{2}{|c|}{$\begin{array}{l}\text { Volumes }{ }^{b}, \\
\text { mL }\end{array}$}} & \multicolumn{3}{|c|}{$\begin{array}{l}\text { Estimated condensed }{ }^{\mathrm{C}} \\
\text { ratio, mol }\end{array}$} & \multirow[t]{3}{*}{$\begin{array}{c}\text { Figure } \\
\text { no. }\end{array}$} \\
\hline & & & & & & & & \multicolumn{2}{|c|}{$\begin{array}{c}\mathrm{CsPO}_{3} \\
/ \mathrm{H}_{2} \mathrm{O}\end{array}$} & \multirow{2}{*}{\begin{tabular}{|c} 
CDP: \\
Addition \\
at \\
300 \\
${ }^{\circ} \mathrm{C}$
\end{tabular}} & \\
\hline & & & & $\begin{array}{l}300 \\
{ }^{\circ} \mathrm{C}\end{array}$ & $\begin{array}{l}400 \\
{ }^{\circ} \mathrm{C}\end{array}$ & total & $\begin{array}{l}\text { conde } \\
\text { nsed }^{c} \\
\text { phase }^{\mathrm{C}}\end{array}$ & $\begin{array}{l}\text { at } 300 \\
{ }^{\circ} \mathrm{C}\end{array}$ & $\begin{array}{l}\text { at } 400 \\
{ }^{\circ} \mathrm{C}\end{array}$ & & \\
\hline 1 & $\begin{array}{c}36.52 \\
7\end{array}$ & 0 & 1.00 & 11.2 & 49.0 & 25.0 & 12.6 & 1.0187 & 1.0733 & $\begin{array}{c}98.17: \\
1.83\end{array}$ & 12 \\
\hline 2 & $\begin{array}{c}21.81 \\
1\end{array}$ & $\begin{array}{l}\mathrm{H}_{2} \mathrm{O}: \\
0.288\end{array}$ & 0.86 & 12.7 & 54.9 & 23.5 & 8.0 & 0.8888 & 0.9913 & $\begin{array}{r}88.88: \\
11.12\end{array}$ & 15 \\
\hline 3 & $\begin{array}{c}11.37 \\
4\end{array}$ & $\begin{array}{l}\mathrm{CsPO}_{3} \\
: 2.618\end{array}$ & 1.25 & 8.5 & 38.5 & 17.3 & 5.3 & 1.3062 & 1.4986 & $\begin{array}{r}76.56: \\
23.44\end{array}$ & 13 \\
\hline 4 & 6.538 & $\begin{array}{l}\mathrm{CsPO}_{3} \\
: 5.996\end{array}$ & 2.00 & 0.6 & 7.15 & 12.9 & 4.3 & 2.0027 & 2.0757 & $\begin{array}{c}\text { 49.93: } \\
50.07\end{array}$ & 14 \\
\hline
\end{tabular}

a See interpolation data in Figure 9.

${ }^{b}$ Volumes were estimated from photographs of cells after quenching to room temperature in upright position.

${ }^{\mathrm{C}}$ Condensed means solid or liquid.

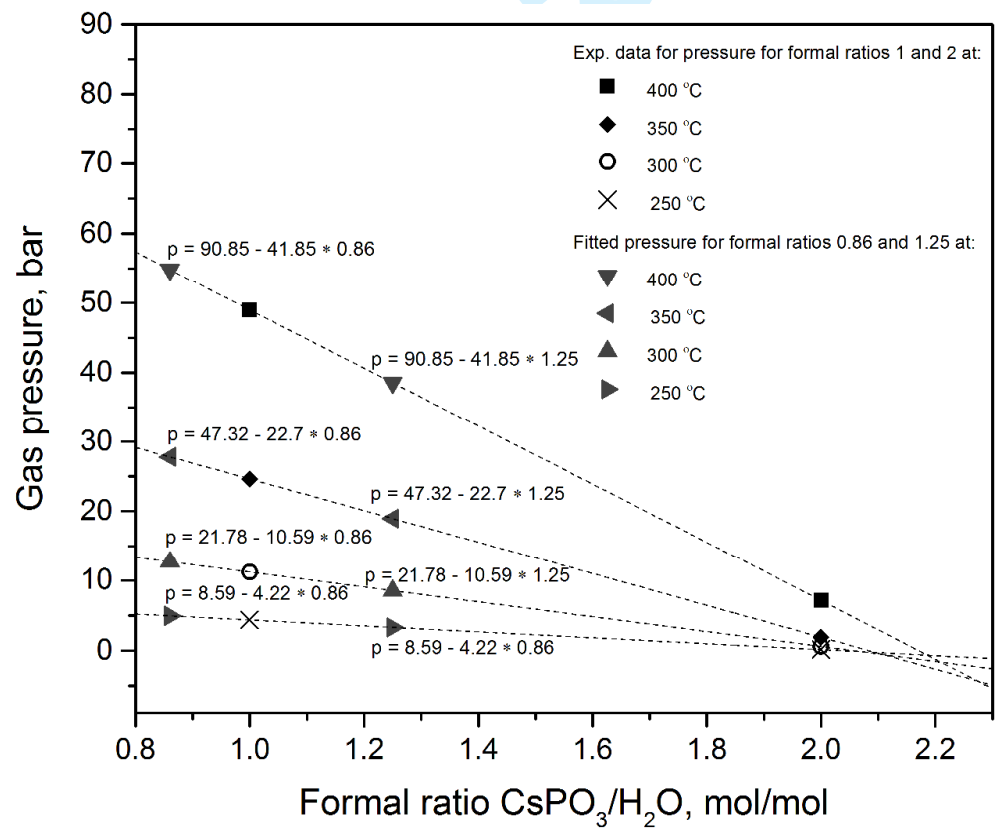

Figure 9. Lines to estimate the water vapor pressure over the condensed "CDP" phases in the conductivity cells. The estimation was based on assumed equilibrium in the cells and the ideal gas law. The vapor pressures $\mathrm{p}$ for the formal mole ratio $\mathrm{CsPO}_{3} / \mathrm{H}_{2} \mathrm{O}=1.0\left(\mathrm{CsH}_{2} \mathrm{PO}_{4}\right)$ or 2.0 
$\left(\mathrm{CsH}_{2} \mathrm{PO}_{4}+\mathrm{CsPO}_{3}\right)$ were read off from Figure 6. The vapor pressure for the other compositions were estimated from the linear expressions $p=a-b \times\left(\mathrm{CsPO}_{3} / \mathrm{H}_{2} \mathrm{O}\right)$ shown, where $\left(\mathrm{CsPO}_{3} /\right.$ $\mathrm{H}_{2} \mathrm{O}$ ) is the known overall "formal composition ratio" given in Table 2 .

3.4.1 Conductivity results Cell 1. The results for our conductivity cell 1 experiment with pure CDP are shown as open circle points in Figure 10 and Figure 11. These logarithmic plots show the conductivity (left ordinate scale $\log _{10} \sigma$ ) versus the reciprocal of the absolute temperature $T$ times 1000 (abscissa 1000/T). The data are detailed in Figure 10 and compared with most results of the literature in Figure 11. The literature data points were obtained by reading values off from highly magnified prints. Some of the prints show different logarithms of $\sigma$ or $\sigma \mathrm{T}$ and for these date we have calculated the corresponding $\log _{10} \sigma$ values for our comparative purpose.

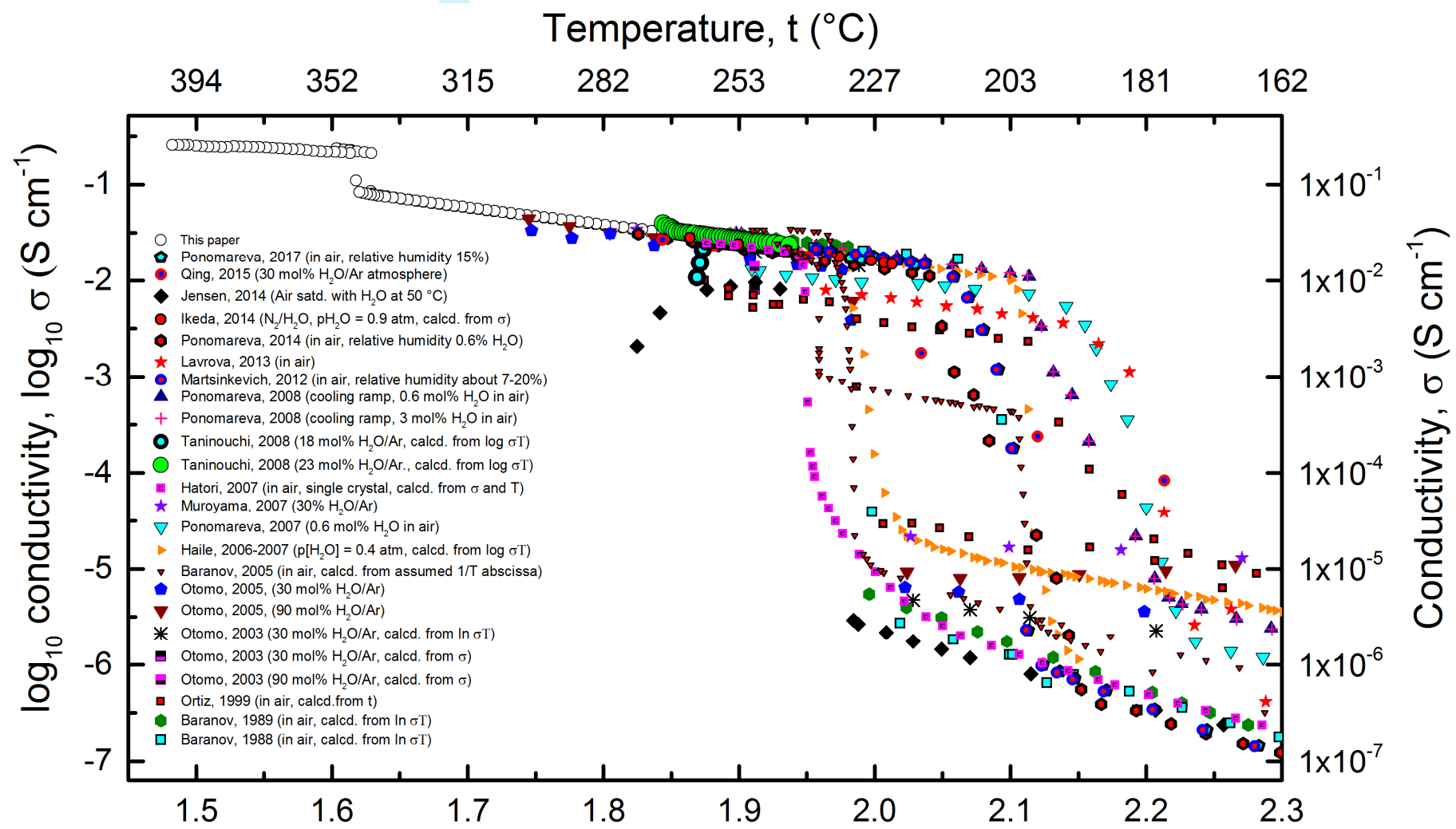

1000 /absolute temperature, $1000 / \mathrm{T}(1000 / \mathrm{K})$

Figure 10. Measured conductivity data (open circles) for pure CDP in cell 1 under its own vapor pressure (from approximately 2 to 49 bar) corresponding to $\mathrm{CsPO}_{3} / \mathrm{H}_{2} \mathrm{O}$ mole ratios from 1.000 to 1.0733 in the temperature range of $25-400{ }^{\circ} \mathrm{C}$, deduced from Table 2 . The data are compared with previously published data for CDP from Ponomareva et al. [32], [36], [40], [113]-[114], Qing et al. [43], Jensen et al. [41], Ikeda et al. [69], Lavrova et al. [78], Martsinkevich et al. [115], Taninouchi et al. [47], Hatori et al. [116], Muroyama et al. [34], Haile et al. [12], Baranov et al. [7]-[9], [112], Otomo et al. [4], [26], and Ortiz et al. [51], [52]. Coordinates for each literature point were read manually pixel by pixel from expanded plots relatively to the axis values by use of the open source GIMP 2.9.6 software (GNU Image Manipulation Program designed for the GNU Operating System from the Free Software Foundation, Inc. in Boston, MA, USA). The "superprotonic" area of this plot is the upper left quarter where the temperature is above $228^{\circ} \mathrm{C}$ and the conductivity above $0.02 \mathrm{~S}$ $\mathrm{cm}^{-1}$. 


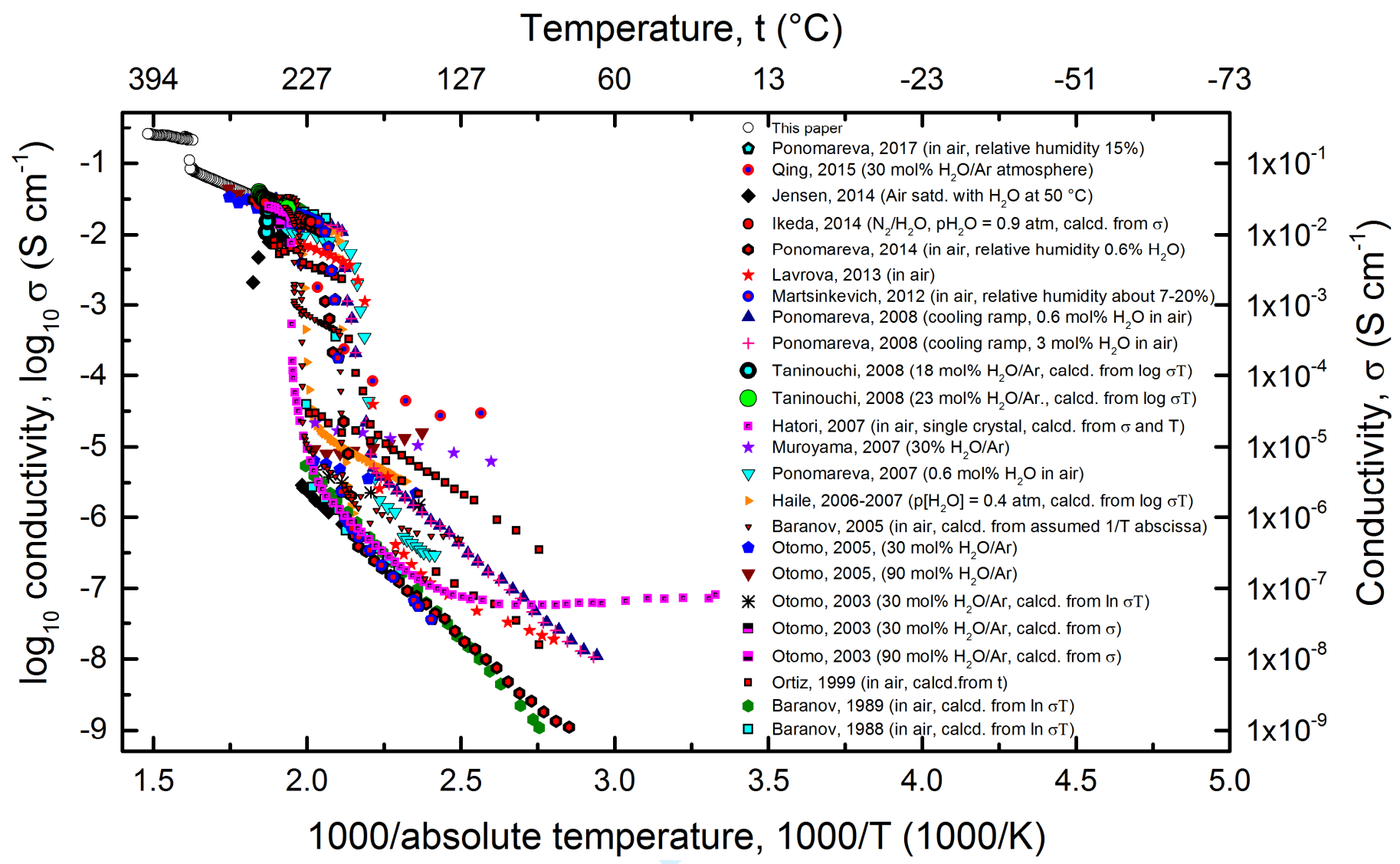

Figure 11. Overview of conductivity data for CDP. Open circles are our cell 1 measurements under its own vapor pressure (from approximately 2 to 49 bar) corresponding to $\mathrm{CsPO}_{3} / \mathrm{H}_{2} \mathrm{O}$ mole ratios from 1.000 to 1.0733 deduced from Table 2. The other data are most other previously published conductivity data for samples claimed to be CDP, see Ponomareva et al. [32], [36], [40], [113][114], Qing et al. [43], Jensen et al. [41], Ikeda et al. [69], Lavrova et al. [78], Martsinkevich et al. [115], Taninouchi et al. [47], Hatori et al. [116], Muroyama et al. [34], Haile et al. [12], Baranov et al. [7]-[9], [112], Otomo et al. [4], [26], and Ortiz et al. [51], [52]. Coordinates from the literature were read from expanded plots as explained in the caption of Figures 1 and 10 (by use of the GIMP 2.9.6 software). Some of the published plots were showing In $\sigma$ or log $\sigma \mathrm{T}$ and these data were converted to the values shown here. The "superprotonic" area of this plot is the upper left corner where $\mathrm{t}>228^{\circ} \mathrm{C}$ and $\sigma>0.02 \mathrm{~S} \mathrm{~cm}^{-1}$.

In Figure 10 - 11 our results are shown for the conductivity of $\mathrm{CsH}_{2} \mathrm{PO}_{4}$ under its own water pressure which varied from approximately 2 to 49 bar depending on the temperature. Simultaneously the actual $\mathrm{CsPO}_{3} / \mathrm{H}_{2} \mathrm{O}$ mole ratios for the composition of the condensed phase was estimated to vary from 1.00 to about 1.02. The free space over the condensed phase (solid or liquid) took up about half of the cell space. When compared to the conductivity results of the literature, see e.g. [12], [40], [43]-[44], [47], [52], [69], [78], [112]-[114], [116], it can be seen that our results are grossly on the same order of magnitude. 
Limiting the discussion to the "superprotonic" part of the conductivity range (Figure 10) we see that measurements above $\sim 300{ }^{\circ} \mathrm{C}$ are not available in prior literature and that the high conductivities that have been reported are leveling off. We think that the explanation is that $\mathrm{CsH}_{2} \mathrm{PO}_{4}$ - if not confined - decompose into mixtures of ortho-, pyro- and meta-phosphates that become less conducting, the higher the temperature and the lower the water vapor pressure. To maintain a high conductivity apparently requires very high water vapor pressures. These results are of interest because it is the first time that the conductivity of molten $\mathrm{CsH}_{2} \mathrm{PO}_{4}$ has been obtained. To measure the conductivity of the liquid requires a water pressure up to 49 bar which explains why it has not been done before.

The conductivity points in Figure 10, both for the "superprotonic" part up to the melting point around $345{ }^{\circ} \mathrm{C}$ and above under pressure follow approximately linear Arrhenius type curves, meaning that the $\sigma$ data can be reproduced by eq. (5). The fitting constants are given in Table 3 .

$$
\log _{10} \sigma=A-B \times 1000 / T
$$

This linear dependency follows the usual elementary equation for ionic conductors [117], [118]. Discussion of such and other expressions are given elsewhere [91]. The constant $A$ corresponds to the intercept of the line at $1000 / T=0 \mathrm{~K}^{-1}$ (at infinite temperature). The slope $B$ is related to the activation energy [8], [12]. Clearly the conductivity increases with temperature in the range studied here, and it is higher in the molten state.

Table 3. Conductivity expressions $\log _{10}\left(\sigma /\left(\mathrm{S} \mathrm{cm}^{-1}\right)\right)=\mathrm{A}-\mathrm{B} \times 1000 / T$ for different electrolyte compositions of solid and molten CDP phases, see equation (5). The formal compositions are given in Table 2. The $\mathrm{R}^{2}$ value approaches 1 for a perfect linear fit.

\begin{tabular}{|c|c|c|c|c|}
\hline Formal composition of electrolyte & State & Intercept A & Slope B, K & $\mathrm{R}^{2}$ \\
\hline \multirow[t]{2}{*}{ Cell 1 (Fig. 12) Pure CDP } & Solid & $\begin{array}{c}1.87504 \pm \\
0.00674\end{array}$ & $\begin{array}{c}1.83133 \pm \\
0.00372\end{array}$ & $\begin{array}{c}0.99976 \\
(60 \text { points })\end{array}$ \\
\hline & Molten & $\begin{array}{c}0.34037 \pm \\
0.05035\end{array}$ & $\begin{array}{c}0.62403 \pm \\
0.0326\end{array}$ & $\begin{array}{c}0.92648 \\
(30 \text { points })\end{array}$ \\
\hline \multirow[t]{2}{*}{ Cell 2 (Fig. 15), added $\mathrm{H}_{2} \mathrm{O} 14.42 \%$} & Solid & $\begin{array}{c}1.60919 \pm \\
0.11759\end{array}$ & $\begin{array}{c}1.55978 \pm \\
0.06341\end{array}$ & $\begin{array}{c}0.98693 \\
\text { (9 points) }\end{array}$ \\
\hline & Molten & $\begin{array}{c}0.32517 \pm \\
0.1647\end{array}$ & $\begin{array}{c}0.64892 \pm \\
0.10589\end{array}$ & $\begin{array}{c}0.859 \\
(7 \text { points })\end{array}$ \\
\hline \multirow[t]{2}{*}{ Cell 3 (Fig. 13 ), added $19.99 \%$ of $\mathrm{CsPO}_{3}$} & Solid & $\begin{array}{c}4.0734 \pm \\
0.16399\end{array}$ & $\begin{array}{l}3.0143 \pm \\
0.09121\end{array}$ & $\begin{array}{c}0.99363 \\
\text { (8 points) }\end{array}$ \\
\hline & Molten & $\begin{array}{c}1.71515 \pm \\
0.05371\end{array}$ & $\begin{array}{c}1.53681 \pm \\
0.03435\end{array}$ & $\begin{array}{c}0.99453 \\
\text { (12 points) }\end{array}$ \\
\hline \multirow{2}{*}{ Cell 4 (Fig. 14), added $49.88 \%$ of $\mathrm{CsPO}_{3}$} & Solid & $\begin{array}{c}4.31843 \pm \\
0.23902\end{array}$ & $\begin{array}{c}3.22063 \pm \\
0.13147\end{array}$ & $\begin{array}{c}0.98845 \\
\text { (8 points) }\end{array}$ \\
\hline & Molten & $\begin{array}{c}2.84835 \pm \\
0.13858\end{array}$ & $\begin{array}{c}2.48053 \pm \\
0.08807\end{array}$ & $\begin{array}{c}0.99 \\
(9 \text { points) }\end{array}$ \\
\hline
\end{tabular}


Our conductivity data from Figures 10 and 11 are shown in Figure 12 and two lines are fitted to the points for the two different states: The range below $345{ }^{\circ} \mathrm{C}$ represents the regime with "superprotonic" conductivity, and at above $345^{\circ} \mathrm{C}$ the salt is molten. As indicated by the dashed arrows the measurements were performed progressively in steps of $2{ }^{\circ} \mathrm{C}$, with at least 40 minutes between each measurement. For each measurement series it was experimentally checked that longer time intervals of equilibration gave identical values. The measurements proved to be very reproducible, and the results did not change significantly after cooling and reheating of the cell (down to and above $\sim 220^{\circ} \mathrm{C}$ ).

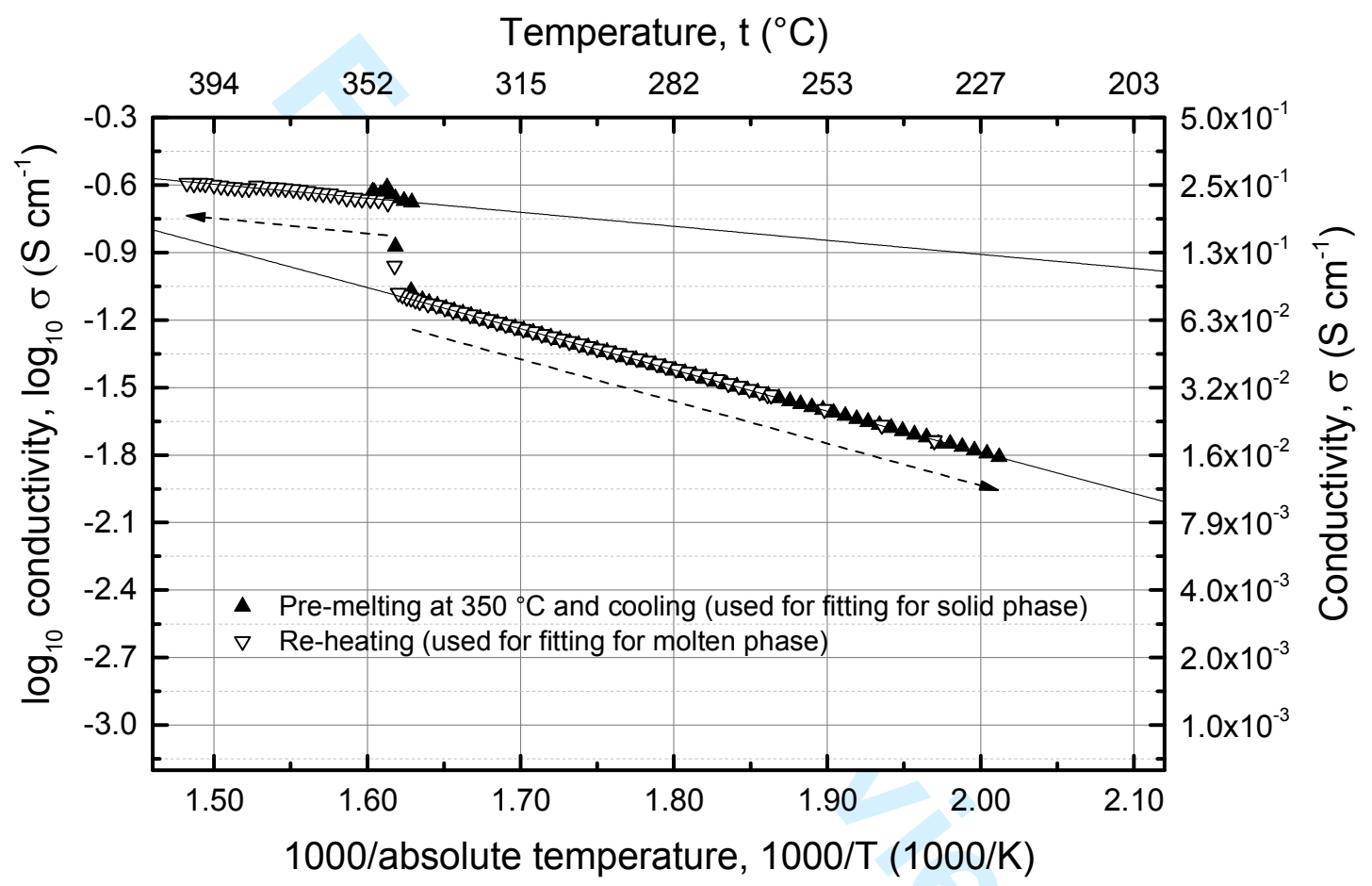

Figure 12. Details of measurements of specific electrical conductivity of $\mathrm{CsH}_{2} \mathrm{PO}_{4}$ (cell 1). We estimate that water has escaped from the condensed phase to form a CDP-CsPO 3 mixture of molar ratio CDP : $\mathrm{CsPO}_{3}=98.17: 1.83$ at e.g. $300{ }^{\circ} \mathrm{C}$ (see Table 2). Dashed lines with arrows indicate the progression of the measurements, starting with the filled triangles and then heating with the open ones. The length and position of the dashed lines indicate the segment, which was used for fitting. Solid lines show the fitting lines given in Table 3 for the molten $\left(t>345^{\circ} \mathrm{C}\right.$ ) and the solid $\left(\mathrm{t}<345^{\circ} \mathrm{C}\right)$ regimes.

3.4.2 Conductivity results for cells 3 and 4. These cells, 3 and 4 , containing new pure $\mathrm{CsH}_{2} \mathrm{PO}_{4}$ with direct addition of $\mathrm{CsPO}_{3}$ (Table 2), were made, sealed and examined, in order to study the conductivity of the system as in a situation where more water has been lost, to simulate CDP measurements in open cells. In this way data were obtained proving the decrease in conductivity of $\mathrm{CsH}_{2} \mathrm{PO}_{4}-\mathrm{CsPO}_{3}$ condensed mixtures when water is lost. The data are presented in Figures 13 and 14. The studied compositions and temperature ranges are specified in the Figure captions and Table 2. The fitting results are reported in Table 3. 
Theoretically the mixture in Figure 14 should give $\mathrm{Cs}_{2} \mathrm{H}_{2} \mathrm{P}_{2} \mathrm{O}_{7}$, but the conversion is probably limited because $\mathrm{CsPO}_{3}$ is a stable compound (m.p. around $735^{\circ} \mathrm{C}$ [47] [55] [119]) and it does not dissolve easily. Two supplementary simple ampoules were made with $\mathrm{CsH}_{2} \mathrm{PO}_{4}: \mathrm{CsPO}_{3}=50: 50$ and $60: 40 \mathrm{~mol} \%$. Based on separate X-ray diffraction observations we estimate a solubility of $\mathrm{CsPO}_{3}$ at around $60: 40 \mathrm{~mol} \%$ on the CDP:CsPO 3 basis at $400{ }^{\circ} \mathrm{C}$ and a post mortem proven presence of a $\mathrm{Cs}_{2} \mathrm{H}_{2} \mathrm{P}_{2} \mathrm{O}_{7}$ phase [120], [121].

3.4.3 Conductivity results Cell 2. We also made a cell 2 containing extra water, and the conductivity data for that cell 2 is shown in Figure 15. This figure shows conductivity measurements with water added to the $\mathrm{CsH}_{2} \mathrm{PO}_{4}$. The excessive amount of water was added as ice, weighed and frozen with liquid nitrogen as described in [80]. Studied compositions and temperature ranges are specified in the Figure captions. The water vapor pressure of this experiment depended markedly on the temperature and there must have been a considerable risk of cell explosion at the elevated temperatures [6].

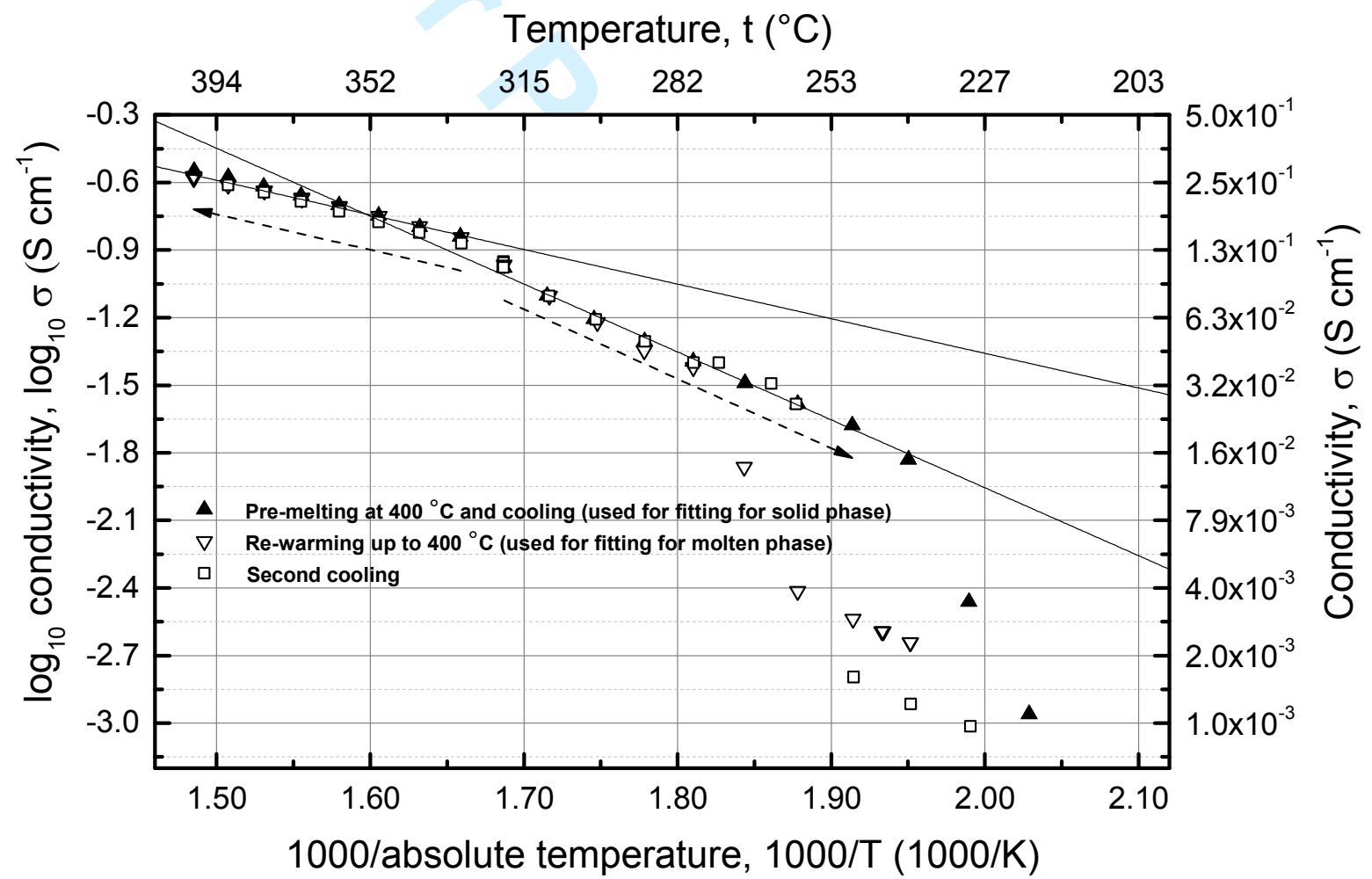

Figure 13. Measured specific electrical conductivity of the $\mathrm{CDP}_{-}-\mathrm{CsPO}_{3}$ mixture of cell 3 of estimated molar ratio $\mathrm{CDP}: \mathrm{CsPO}_{3}$ at $300{ }^{\circ} \mathrm{C}$ of $76.56: 23.44$ (see Table 2). Solid lines show the fitting lines given in Table 3 for the molten $\left(t>\sim 325^{\circ} \mathrm{C}\right.$ ) and the solid $\left(t<\sim 325^{\circ} \mathrm{C}\right.$ ) regimes. Dashed lines with arrows show progression of measurements, starting with the filled triangles to premelt the system up to $\sim 400{ }^{\circ} \mathrm{C}$ and then cooling, followed by rewarming with the open ones, and finally second cooling with the open squares. 


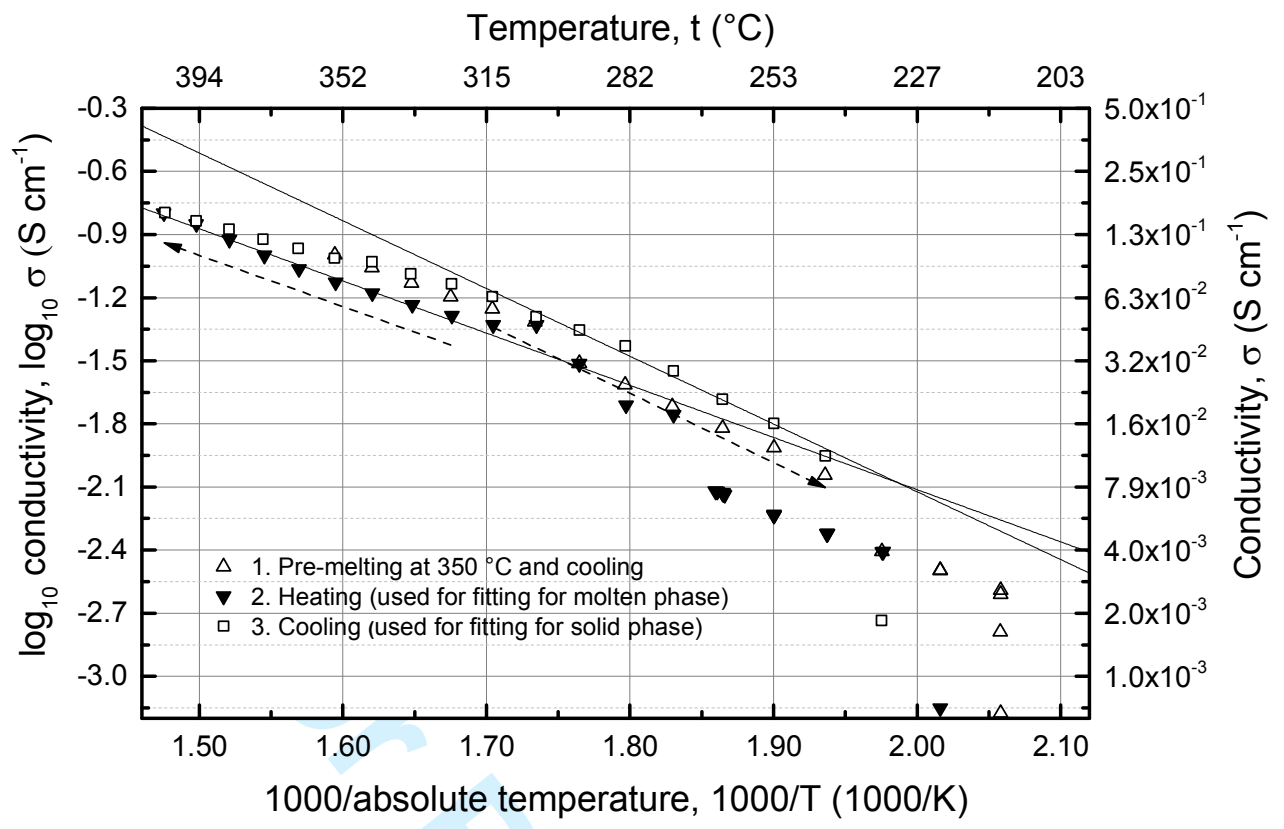

Figure 14. Measurement of specific electrical conductivity of a saturated $\mathrm{CDP}-\mathrm{CsPO}_{3}$ mixture (cell 4) vs. temperature, having an estimated $\mathrm{CDP}: \mathrm{CsPO}_{3}$ molar ratio of $49.93: 50.07$ at $300{ }^{\circ} \mathrm{C}$, (see Table 2). Dashed arrows show progression of measurements. Solid lines show fitted linear expressions (Table 3).

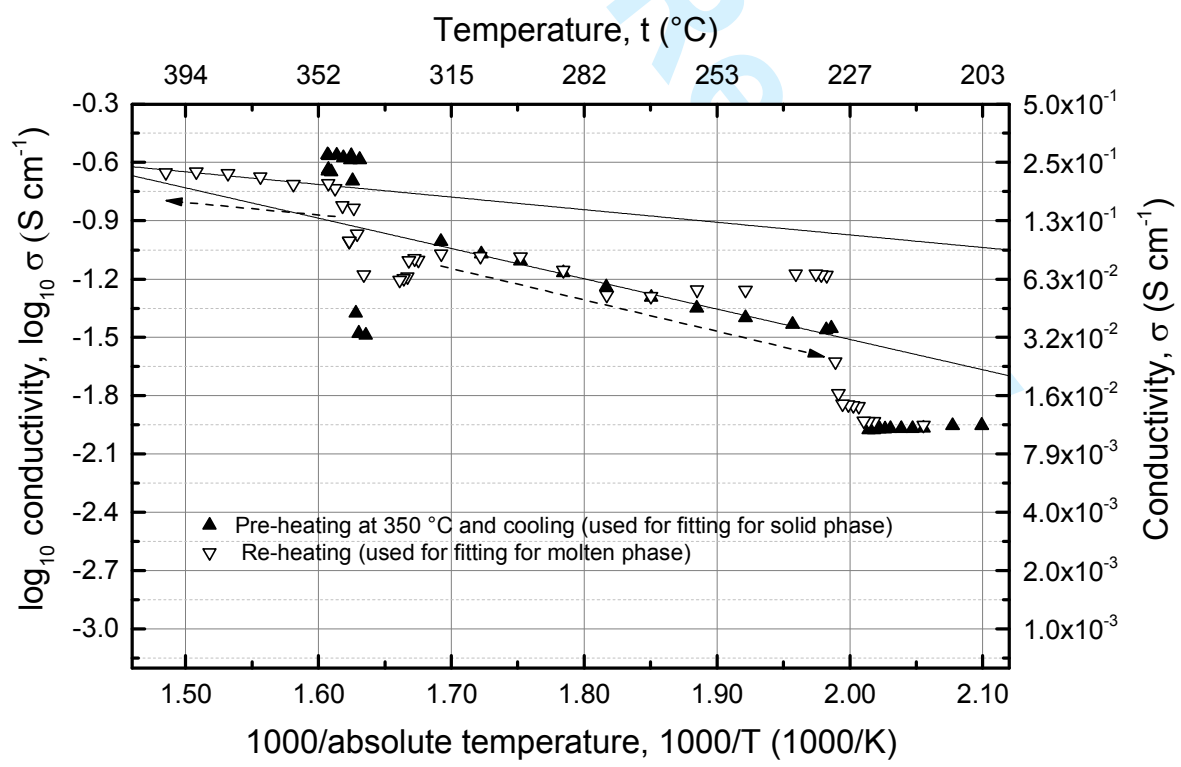

Figure 15. Specific electrical conductivity measured vs. temperature for cell 2 , a CDP- $\mathrm{H}_{2} \mathrm{O}$ mixture of an estimated molar ratio CDP : $\mathrm{H}_{2} \mathrm{O}$ at $300{ }^{\circ} \mathrm{C}$ of $88.88: 11.12$ (see Table 2). Solid lines represent linear fittings (Table 3). Dashed arrows indicate how progression of measurements went on. The reason for the dip in conductivity at the melting point is not known. 
As expected the conductivity increases with temperature in our closed cells (slope B in positive in Table 3). It is however clear that in order to obtain the preferred high conductivity, the water vapor pressure has to be much higher than the $0.3-0.4$ bar often mentioned in the previous literature [12]. If the water pressure is low water tends to leave the $\mathrm{CDP}$ electrolyte to form $\mathrm{CsPO}_{3}$ via eq. (1). The result of adding $\mathrm{CsPO}_{3}$ to $\mathrm{CsH}_{2} \mathrm{PO}_{4}$ is shown in Figure 13 and 14, and the conductivity clearly decreased, the more the more $\mathrm{CsPO}_{3}$ was added.

\subsection{Conductivity prediction in the $\mathrm{CsH}_{2} \mathrm{PO}_{4}-\mathrm{CsPO}_{3}-\mathrm{H}_{2} \mathrm{O}$ system}

Obviously one would desire to predict the conductivity as a function of temperature as well as compositions. We present here a way to perform such a prediction:

1. First perform linear fittings to calculate values of $A$ and $B$ in Eq. (5) on the basis of the data in Figures 10-13 (shown in Table 3).

2. Then from the values of $A$ and $B$ construct a diagram of the conductivity as a function of composition and temperature, as shown in Figure 16.

In Figure 16 trends of changes in conductivity, depending on the composition of the melt, are shown projected to " 0 " in $\mathrm{CsPO}_{3} / \mathrm{H}_{2} \mathrm{O}$ content ratio. Non-linear polynomial curve fitting was applied to make projections to the "0,0" point. The equation used was a cubic type of function, eq. (6),

$$
\sigma=A_{1}(t)+B_{1} \times X+C_{1} \times X^{2}
$$

where $\sigma$ is the conductivity in $\mathrm{S} \mathrm{cm}^{-1}, \mathrm{t}$ is the temperature in ${ }^{\circ} \mathrm{C}$ and $\mathrm{X}$ is the total molar content ratio of $\mathrm{CsPO}_{3} / \mathrm{H}_{2} \mathrm{O}$. The resulting parameters for fitting this model to our measured data at different temperatures and compositions can be found in Table 4. It must be emphasised that measurements of the conductivity in the region for molar ratios of $\mathrm{CsPO}_{3} / \mathrm{H}_{2} \mathrm{O}$ below the value 1 are limited due to the practical problem that quartz cells in the used technique cannot stand pressures much higher than what we used. This is why we only have the point at the origin.

It was also an objective to determine analytical expressions for the conductivity versus temperature. Such information is essential for the optimization of the high temperature water electrolysis application of the electrolyte. 


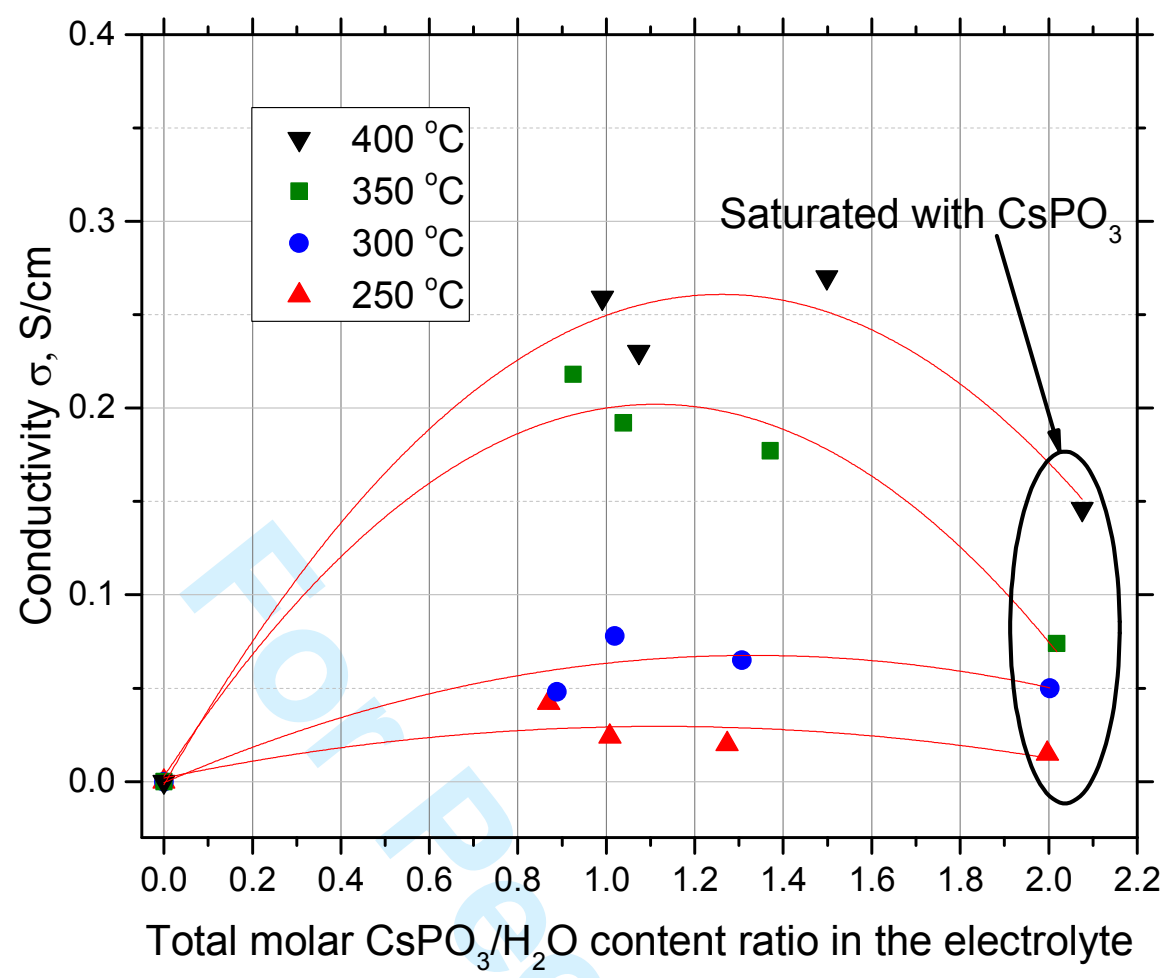

Figure 16. Dependence of the conductivity of melts in the $\mathrm{CsH}_{2} \mathrm{PO}_{4}-\mathrm{CsPO}_{3}-\mathrm{H}_{2} \mathrm{O}$ electrolyte as a function of composition at different temperatures, projected to " 0 " in the $\mathrm{CsPO}_{3} / \mathrm{H}_{2} \mathrm{O}$ content.

Table 4. Fitting parameters, of use for data in Figure 16, obtained at different temperatures.

\begin{tabular}{|c|c|c|c|c|}
\hline Temperature & $250^{\circ} \mathrm{C}$ & $300^{\circ} \mathrm{C}$ & $350^{\circ} \mathrm{C}$ & $400^{\circ} \mathrm{C}$ \\
\hline & $\begin{array}{l}\text { Value and } \\
\text { Standard error }\end{array}$ & $\begin{array}{l}\text { Value and } \\
\text { Standard error }\end{array}$ & $\begin{array}{l}\text { Value and } \\
\text { Standard error }\end{array}$ & $\begin{array}{l}\text { Value and } \\
\text { Standard error }\end{array}$ \\
\hline$A_{1}(t)$ & $0.00193 \pm 0.01236$ & $-6.04037 \times 10^{-4} \pm 0.0132$ & $0.00273 \pm 0.01961$ & $-0.00163 \pm 0.02333$ \\
\hline$B_{1}(t)$ & $0.0493 \pm 0.02476$ & $0.10242 \pm 0.02635$ & $0.35849 \pm 0.03894$ & $0.41629 \pm 0.04544$ \\
\hline $\mathrm{C}_{1}(\mathrm{t})$ & $-0.022 \pm 0.01175$ & $-0.03847 \pm 0.01252$ & $-0.16125 \pm 0.01848$ & $-0.16507 \pm 0.02111$ \\
\hline Reduced $x^{2 a}$ & $1.55066 \times 10^{-4}$ & $1.76568 \times 10^{-4}$ & $3.89456 \times 10^{-4}$ & $5.50744 \times 10^{-4}$ \\
\hline Adjusted $\mathrm{R}^{2 \mathrm{a}}$ & 0.3293 & 0.79802 & 0.95392 & 0.95628 \\
\hline
\end{tabular}




\section{Proof of Water Electrolysis by Raman Spectroscopy}

It was considered important to demonstrate experimentally that water electrolysis indeed could be done. We made an electrolysis cell as described in the experimental section, filled it with $\mathrm{CsH}_{2} \mathrm{PO}_{4}$ and $\mathrm{N}_{2}$, and heated it to a high temperature $\left(\sim 355^{\circ} \mathrm{C}\right)$ to let a melt be formed. It proved possible to successfully supply potential differences of about $1.6-2.2 \mathrm{~V}$ to the cell. This caused currents of about $0.1 \mathrm{~mA}$ to pass through the cell via its two coiled platinum wire electrodes (areas $2.5 \mathrm{~cm}^{2}$ ). Electrolysis was performed 8 times in periods of each 800 seconds duration. Resistances were about $20 \Omega$ and current densities were on the order of $40 \mathrm{~mA} / \mathrm{cm}^{2}$. When currents were passing through the CDP liquid, formation of small bubbles could be seen at the electrodes, with more gas coming from the negative electrode, and more the higher the current. Gas phase Raman spectra were recorded in between the electrolysis periods, see Figure 17. It was difficult to get good gas spectra because of the protective net and the short path length of the cell, but without any doubt the spectra showed formation of new characteristic sharp bands. As expected [6] the bands are assignable to $\mathrm{H}_{2}$ hydrogen $\mathrm{S}$ rotational bands (up to $1500 \mathrm{~cm}^{-1}$ ), and oxygen and hydrogen rot-vib Q-branch bands at $\sim 1555\left(\mathrm{O}_{2}\right)$ and $\sim 4156 \mathrm{~cm}^{-1}\left(\mathrm{H}_{2}\right)$, in addition to gas phase bands from the formed water and the added $\mathrm{N}_{2}$ reference, see also Figure 5 and Table 5 [97]-[98], [100], [122][123]. These bands were not present before start of the electrolysis. In this way the splitting of water, into $2 \mathrm{H}_{2}$ and $\mathrm{O}_{2}$ molecules can indeed be demonstrated. No other gases seemed to appear during the electrolysis, but a weak $\mathrm{CO}_{2}$ signal was seen, possibly originating from soot from the welding of Pt-electrodes to the W-pins.

The amount of $\mathrm{H}_{2}$ relative to $\mathrm{O}_{2}$ seems to be near the expected 2 to 1 ratio. The $\mathrm{O}_{2}$ signal is being so small in Figure 17 because of the known small Raman scattering cross section of $\mathrm{O}_{2}$ relative to that of $\mathrm{H}_{2}$. Note that the situation is complicated by the hydrogen presence as both para- $\mathrm{H}_{2}$ and ortho- $\mathrm{H}_{2}$, see e.g. [124].

The relative stability of the $2 \mathrm{H}_{2}+\mathrm{O}_{2}$ molecular mixture towards reformation of water, for 14 hours without electrolysis at a temperature of $285^{\circ} \mathrm{C}$, possibly is due to lack of gas contact with the platinum electrodes which were covered by the solidified melt. Simultaneous presence of water molecules in the gas and in the superconductive phase might reduce the speed of the direct recombination reaction $2 \mathrm{H}_{2}+\mathrm{O}_{2} \rightarrow 2 \mathrm{H}_{2} \mathrm{O}$. And if this reaction occurs, the only thing happening will be formation of water vapor that adds not much new to the spectra. However, the observed simultaneous presence of $\mathrm{H}_{2}$ and $\mathrm{O}_{2}$ molecules in the gas phase and thus the water splitting remains a fact. 


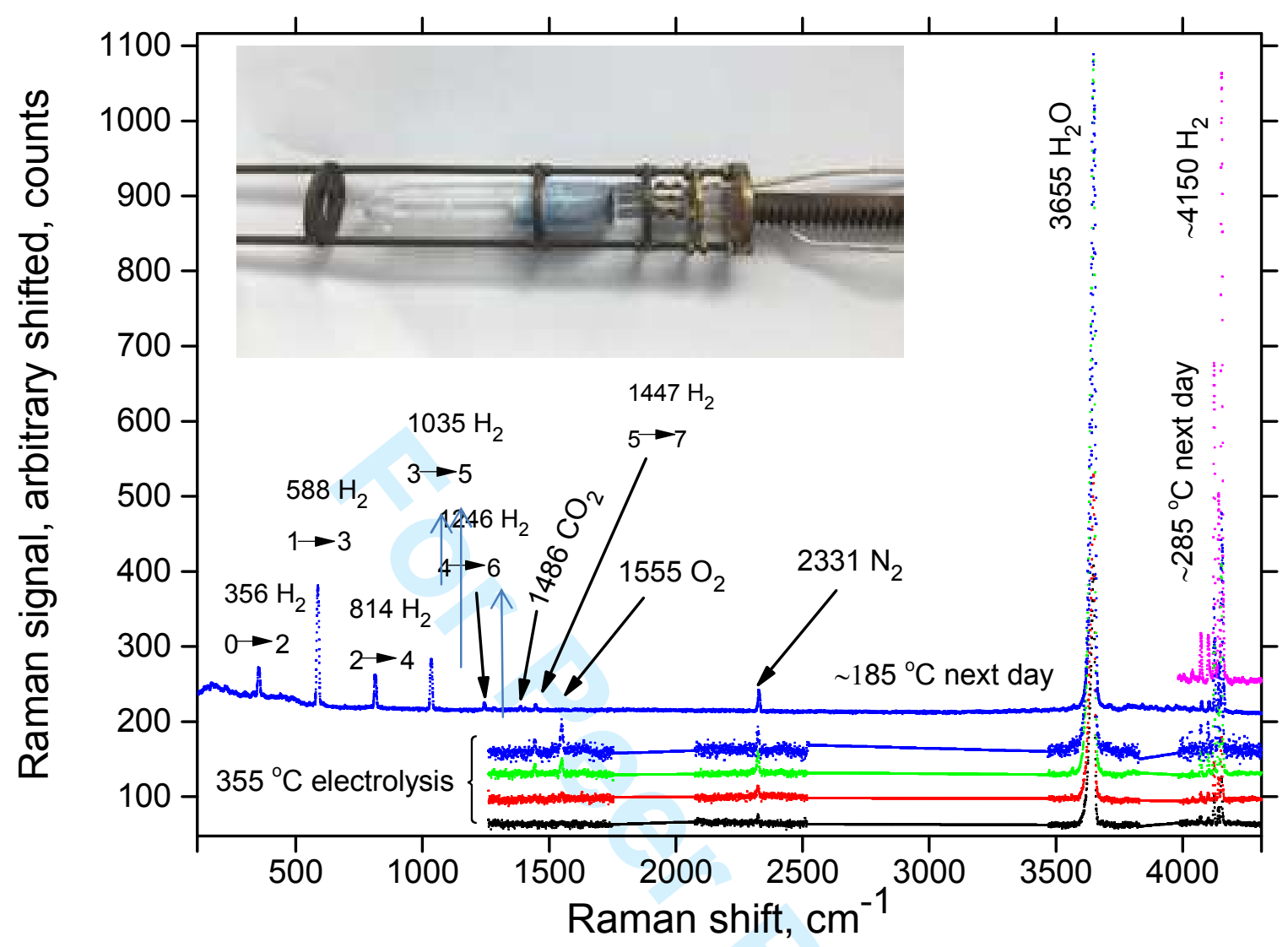

Figure 17. From below: Four typical Raman spectra of the gas phase of the electrolysis cell with $\mathrm{CDP}$ and 0.5 bar of $\mathrm{N}_{2}$ reference gas, obtained during electrolysis of $\mathrm{CsH}_{2} \mathrm{PO}_{4}$ at $355^{\circ} \mathrm{C}$. The cell sitting in its holder after the experiment is shown in the inserted photo. The blue color is thought to come from $\mathrm{W}(\mathrm{V}, \mathrm{VI})$-compounds formed from the pins during the electrolysis. The top spectrum shows the gas phase after stop of electrolysis and leaving the cell at $285^{\circ} \mathrm{C}$ over-night. The long blue spectrum shows the gas after cooling to $\sim 185^{\circ} \mathrm{C}$. The pronounced bands are labeled with wavenumber values and are due to $\mathrm{H}_{2}$ rotational transitions, and $\mathrm{CO}_{2}, \mathrm{O}_{2}, \mathrm{~N}_{2}, \mathrm{H}_{2} \mathrm{O}$ and $\mathrm{H}_{2}$ vibrations. The gas spectra are weak because of the protective steel net around the experiment. A $532 \mathrm{~nm}$ laser running at $\sim 2 \mathrm{~W}$ was used during recording of the spectra. 
Table 4. Raman bands $\left(\mathrm{cm}^{-1}\right)$ observed in the gas phase during and after electrolysis.

\begin{tabular}{|c|c|l|l|}
\hline $\begin{array}{c}\text { This work at high temp. } \\
/ \mathrm{cm}^{-1}\end{array}$ & $\begin{array}{l}\text { Literature at room } \\
\text { temp. }\end{array}$ & References & Assignment \\
\hline 355.6 & 354.4 & {$[122],[123],[125]$} & para $\mathrm{H}_{2}$ rot $0 \rightarrow 2$ \\
\hline 588 & 587.0 & {$[122],[123],[125]$} & ortho $\mathrm{H}_{2}$ rot $1 \rightarrow 3$ \\
\hline 815 & 814.4 & {$[122],[123],[125]$} & para $\mathrm{H}_{2}$ rot $2 \rightarrow 4$ \\
\hline 1035 & 1034.7 & {$[122],[123],[125]$} & ortho $\mathrm{H}_{2}$ rot $3 \rightarrow 5$ \\
\hline 1246 & 1246.1 & {$[123],[125]$} & para $\mathrm{H}_{2}$ rot $4 \rightarrow 6$ \\
\hline 1447 & 1447.3 & {$[123],[125]$} & ortho $\mathrm{H}_{2}$ rot $5 \rightarrow 7$ \\
\hline$\sim 1486$ & $\sim 1489$ & {$[97],[98],[100]$} & Strongst $\mathrm{CO}$ line, formed from $\mathrm{C}+\mathrm{O}_{2}$ \\
\hline$\sim 1555$ & $\sim 1555$ & {$[97],[98],[100]$} & Q branch of oxygen $\left(\mathrm{O}_{2}\right)$ \\
\hline$\sim 2331$ & $\sim 2331$ & {$[97],[98],[100]$} & Q branch of added $\mathrm{N}_{2}$ \\
\hline$\sim 3655$ & $\sim 3655$ & {$[97],[98],[100]$} & Q branch $v_{1}$ sym str band of $\mathrm{H}_{2} \mathrm{O}$ \\
\hline$\sim 4073$ & 4073.7 & {$[125]$} & rot-vib Q branch $\mathrm{H}_{2} 5 \rightarrow 5$ \\
\hline$\sim 4103$ & 4102.6 & {$[125]$} & rot-vib Q branch $\mathrm{H}_{2} 4 \rightarrow 4$ \\
\hline$\sim 4126$ & 4125.9 & {$[125]$} & rot-vib Q branch $\mathrm{H}_{2} 3 \rightarrow 3$ \\
\hline$\sim 4144$ & 4143.5 & {$[125]$} & rot-vib $\mathrm{Q}$ branch $\mathrm{H}_{2} 2 \rightarrow 2$ \\
\hline$\sim 4156$ & 4155.2 & {$[125]$} & rot-vib $\mathrm{Q}$ branch $\mathrm{H}_{2} 1 \rightarrow 1$ \\
\hline$\sim 4163$ & 4161.2 & {$[125]$} & rot-vib $\mathrm{Q}$ branch $\mathrm{H}_{2} 0 \rightarrow 0$ \\
\hline
\end{tabular}

\section{Conclusions}

$\mathrm{CsH}_{2} \mathrm{PO}_{4}(\mathrm{CDP})$ was prepared and investigated for use as a rather high-temperature liquid electrolyte for splitting water to hydrogen and oxygen. The melting point of our CDP was found to be at around $346{ }^{\circ} \mathrm{C}$, confirming several quite old careful measurements by e.g. Rapoport et al. [19]. Also many researchers have previously claimed CDP to be dependent on the surrounding partial pressure of water, and this tendency was confirmed in our experiments.

We have determined the vapor pressure above CDP by means of a recently developed Raman method. The pressure is considerable at higher temperatures, reaching perhaps values as high as 23 bar at $355^{\circ} \mathrm{C}$ (Figure 6). These pressures are considerably higher than claimed in previous reports. It was therefore realized that experiments must be conducted in closed cells or under otherwise confined circumstances.

The pressure of water above $\mathrm{CsH}_{2} \mathrm{PO}_{4}$ at elevated temperatures is thus much higher than earlier thought. Along this rationale we have determined the conductivity of CDP, and attempted to obtain reliable corrected data for the conductivity of CDP at very high temperatures, up to about $400{ }^{\circ} \mathrm{C}$ (Figure 10-11). At these rather high temperatures we have obtained record high conductivities of molten CDP approaching values of perhaps $\sim 0.3 \mathrm{~S} \mathrm{~cm}^{-1}$, when saturated under its own vapor pressure or confined.

These conductivity values cannot be measured in an open system and sealed systems had to be used. In order to make accurate measures of e.g. the electrical conductivity the salt has to be kept under its own vapor pressure to avoid decomposition into mixtures of pyro- and orthophosphates.

Furthermore the conductivity of the salt - in its superprotonic and molten states - does not vary much if a moderate part of the orthophosphate is replaced with pyrophosphate. In the superprotonic and molten states under pressure the ionic structure may not be affected very 
much, and the protons may be travelling around very fast. If the salt loses water it will turn into a mixture of orthophosphate and pyrophosphate from which metaphosphates eventually will separate out and at even higher water losses the conductivity will be markedly reduced (figure 16).

We have - like previously for the $\mathrm{KH}_{2} \mathrm{PO}_{4}$ system [5], [6] - used Raman spectroscopy to demonstrate that electrolysis is possible whereby water molecules can be split to form only hydrogen and oxygen. We conclude that a new potentially high efficiency electrolyte has been found for intermediate temperature pressurized water electrolysis (at $\sim 350{ }^{\circ} \mathrm{C}$ ), with great perspectives for development of efficient water electrolysis. At such high temperatures it should be possible to find cheap and effective electrodes.

\section{Acknowledgements}

This investigation has been supported by "ForskEL-programmet", grant.nr. 2016-1-12449 under the Danish Energinet.dk research programme. We would like to thank Larisa Seerup of DTU Energy for performing the Differential Scanning Calorimetry and CDP X-ray measurements and Kenny Ståhl of DTU Chemistry for identifying the $\mathrm{Cs}_{2} \mathrm{H}_{2} \mathrm{P}_{2} \mathrm{O}_{7}$ phase by X-ray diffraction. Jan Patrick Scholer competently made the quartz cells in his glass blowing workshop.

\section{References:}

[1] Ulleberg $\varnothing$, Nakken T, Eté A (2010) The wind/hydrogen demonstration system at Utsira in Norway: evaluation of system performance using operational data and updated hydrogen energy system modeling tools. Int J Hydrogen Energy 35(5):1841-1852.

[2] Ebbesen SD, Jensen SH, Hauch A, Mogensen MB (2014) High Temperature Electrolysis in Alkaline Cells, Solid Proton Conducting Cells, and Solid Oxide Cells. Chem Rev 114(21):1069710734.

[3] Papandrew AB, Zawodzinski TA (2014) Nickel Catalysts for Hydrogen Evolution from $\mathrm{CsH}_{2} \mathrm{PO}_{4}$. J Power Sources 245:171-174.

[4] Otomo J, Tamaki T, Nishida S, Wang SQ, Ogura M, Kobayashi T, Wen CJ, Nagamoto H, Takahashi $\mathrm{H}$ (2005) Effect of water vapor on proton conduction of cesium dihydrogen phosphate and application to intermediate temperature fuel cells. J Appl Electrochem 35:865-870.

[5] Nikiforov AV, Berg RW, Petrushina IM, Bjerrum NJ (2016) Specific electrical conductivity in molten potassium dihydrogen phosphate $\mathrm{KH}_{2} \mathrm{PO}_{4}$ - an electrolyte for water electrolysis at $\sim 300$ ${ }^{\circ} \mathrm{C}$. Appl Energy 175:545-550.

[6] Berg RW, Nikiforov AV, Petrushina IM, Bjerrum NJ (2016) Water vapor pressure over molten $\mathrm{KH}_{2} \mathrm{PO}_{4}$ and demonstration of water electrolysis at $\sim 300{ }^{\circ} \mathrm{C}$. Appl Energy 180:269-275.

[7] Baranov Al, Khiznichenko VP, Sandler VA, Shuvalov LA (1988) Frequency dielectric dispersion in the ferroelectric and superionic phases of $\mathrm{CsH}_{2} \mathrm{PO}_{4}$. Ferroelectrics 81:183-186. 
[8] Baranov Al, Khiznichenko VP, Shuvalov LA (1989) High temperature phase transitions and proton conductivity in some KDP-family crystals. Ferroelectrics 100:135-141.

[9] Baranov Al, Merinov BV, Tregubchenko AV, Khiznichenko VP, Shuvalov LA, Schagina NM (1989) Fast Proton Transport in Crystals with a Dynamically Disordered Hydrogen-Bond Network. Solid State Ionics 36(3-4):279-282.

[10] Haile SM (1999) Hydrogen-bonding and phase transitions in proton-conducting solid acids. Materials Research Society Symposia Proceedings 547:315-326.

[11] Haile SM, Boysen DA, Chisholm CRI (2001) Solid acids as fuel cell electrolytes. Nature 410(6831):910-912.

[12] Haile SM, Chisholm CRI, Sasaki K, Boysen DA, Uda T (2006-2007) Solid acid proton conductors: from laboratory curiosities to fuel cell electrolytes. Faraday Discuss. 134:17-39.

[13] Chisholm CRI, Boysen DA, Papandrew AB, Zecevic S, Cha S, Sasaki KA, Varga Á, Giapis KP, Haile SM (2009) From laboratory breakthrough to technological realization: The development path for solid acid fuel cells. Electrochem Soc Interface 18(3):53-59.

[14] Paschos O, Kunze J, Stimming U, Maglia F (2011) A review on phosphate based, solid state, protonic conductors for intermediate temperature fuel cells. J Phys: Condens Matter 23(23):234110 (26pp).

[15] Goñi-Urtiaga A, Presvytes D, Scott K (2012) Solid acids as electrolyte materials for proton exchange membrane (PEM) electrolysis: review. Int J Hydrogen Energy 37:3358-3372.

[16] Piñeres I, Ortiz E, De la Hoz C, Tróchez JC, León C (2017) On the nature of the $\mathrm{KH}_{2} \mathrm{PO}_{4}$ high-temperature transformation. Ionics 23:1187-1195.

[17] Uesu Y, Kobayashi J, (1976) Crystal Structure and Ferroelectricity of Cesium Dihydrogen Phosphate $\mathrm{CsH}_{2} \mathrm{PO}_{4}$. Phys Stat Solidi A 34:475-481.

[18] Semmingsen D, Ellenson WD, Frazer BS, Shirane G (1977) Neutron-Scattering Study of the Ferroelectric Phase Transition in $\mathrm{CsD}_{2} \mathrm{PO}_{4}$. Phys Rev Lett 38(22):1299-1302.

[19] Rapoport E, Clark JB, Richter PW (1978) High-Pressure Phase Relations of $\mathrm{RbH}_{2} \mathrm{PO}_{4}$, $\mathrm{C}_{5} \mathrm{H}_{2} \mathrm{PO}_{4}$, and $\mathrm{KD}_{2} \mathrm{PO}_{4}$. J Solid State Chem. 24(3-4):423-433.

[20] Baranowski B, Friesel M, Lundén A (1988) Pressure dependence of high temperature phase transitions in solid $\mathrm{CsH}_{2} \mathrm{PO}_{4}$ and $\mathrm{RbH}_{2} \mathrm{PO}_{4}$. Phys Scripta 37(2):209-213.

[21] Boysen, DA, Haile SM, Liu H, Secco RA (2003) High-Temperature Behavior of $\mathrm{CsH}_{2} \mathrm{PO}_{4}$ under both Ambient and High Pressure Conditions. Chem Mater 15:727-736.

[22] Botez CE, Hermosillo JD, Zhang J, Qian J, Zhao Y, Majzlan J., Chianelli RR, Pantea C (2007) 
High-temperature phase transitions in $\mathrm{CsH}_{2} \mathrm{PO}_{4}$ under ambient and high-pressure conditions: $\mathrm{A}$ synchrotron X-ray diffraction study. J Chem Phys 127:194701, 1-6.

[23] Botez CE, Carbajal D, Adiraju VAK, Tackett RJ, Chianelli RR (2010) Intermediate-temperature polymorphic phase transition in $\mathrm{KH}_{2} \mathrm{PO}_{4}$ : a synchrotron X-ray diffraction study. J Phys Chem Solids 71:1576-1580.

[24] Metcalfe B, Clark JB (1978) Differential scanning calorimetry of $\mathrm{RbH}_{2} \mathrm{PO}_{4}$ and $\mathrm{CsH}_{2} \mathrm{PO}_{4}$. Thermochim Acta, 24(1):149-153.

[25] Wada M, Sawada A, Ishibashi Y (1979) Some High-Temperature Properties and the Raman Scattering Spectra of $\mathrm{CsH}_{2} \mathrm{PO}_{4}$. J Phys Soc Jpn 47(5):1571-1574.

[26] Otomo J, Minagawa N, Wen C, Eguchi K, Takahashi H (2003) Protonic conduction of $\mathrm{CsH}_{2} \mathrm{PO}_{4}$ and its composite with silica in dry and humid atmospheres. Solid State lonics 156:357369.

[27] Boysen DA, Uda T, Chisholm CRI, Haile SM (2004) High-performance solid acid fuel cells through humidity stabilization. Science 303(5654):68-70.

[28] Uda T, Haile SM (2005) Thin-membrane solid-acid fuel cell. Electrochem Solid-State Lett 8(5): A245-A246.

[29] Matsui T, Kukino T, Kikuchi R, Eguchi K (2005) An Intermediate Temperature ProtonConducting Electrolyte Based on a $\mathrm{CsH}_{2} \mathrm{PO}_{4} / \mathrm{SiP}_{2} \mathrm{O}_{7}$ Composite. Electrochem Solid-State Lett 8(5): A256-A258.

[30] Matsui T, Kukino T, Kikuchi R, Eguchi K (2006) Intermediate-Temperature Fuel Cell Employing $\mathrm{CsH}_{2} \mathrm{PO}_{4} / \mathrm{SiP}_{2} \mathrm{O}_{7}$-Based Composite Electrolytes. J Electrochem Soc 153(2):A339A342.

[31] Tezuka T, Tadanaga K, Hayashi A, Tatsumisago M (2006) Preparation of proton conductive composites with $\mathrm{CsHSO}_{4} / \mathrm{CsH}_{2} \mathrm{PO}_{4}$ and phosphosilicate gel. Solid State lonics 177:2463-2466.

[32] Ponomareva VG, Shutova ES (2007) High-temperature behavior of $\mathrm{CsH}_{2} \mathrm{PO}_{4}$ and $\mathrm{CsH}_{2} \mathrm{PO}_{4}-$ $\mathrm{SiO}_{2}$ composites. Solid State lonics 178:729-734.

[33] Baranov Al, Kopnin EM, Grebenev VV, Sin A, Zaopo A, Dubitsky Y, Caracino P (2007) Influence of humidity and thermal decomposition on the protonic conductivity of single and polycrystalline $\mathrm{CsH}_{2} \mathrm{PO}_{4}$. Solid State lonics 178:657-660.

[34] Muroyama H, Kudo K, Matsui T, Kikuchi R, Eguchi K (2007) Electrochemical properties of $\mathrm{MH}_{2} \mathrm{PO}_{4} / \mathrm{SiP}_{2} \mathrm{O}_{7}$-based electrolytes ( $\mathrm{M}=$ =alkaline metal) for use in intermediate-temperature fuel cells. Solid State Ionics 178:1512-1516.

[35] Otomo J, Ishigooka T, Kitano T, Takahashi H, Nagamoto H (2008) Phase transition and proton transport characteristics in $\mathrm{CsH}_{2} \mathrm{PO}_{4} / \mathrm{SiO}_{2}$ composites. Electrochim Acta 53:8186-8195. 
[36] Ponomareva VG, Shutova ES, Lavrova GV (2008) Electrical conductivity and thermal stability of (1-x) $\mathrm{CsH}_{2} \mathrm{PO}_{4} / \mathrm{xSiP}(y) \mathrm{O}(z)(\mathrm{x}=0.2-0.7)$ composites. Inorg Mater 44(9):1009-1014.

[37] Bochetta P, Ferraro R, Di Quarto F (2009) Advances in anodic alumina membranes thin film fuel cell: $\mathrm{CsH}_{2} \mathrm{PO}_{4}$ pore-filler as proton conductor at room temperature. J Power Sources 187(1): $49-56$.

[38] Li Z, Tang T (2010) High-temperature thermal behaviors of $\mathrm{XH}_{2} \mathrm{PO}_{4}(\mathrm{X}=\mathrm{Cs}, \mathrm{Rb}, \mathrm{K}, \mathrm{Na})$ and $\mathrm{LiH}_{2} \mathrm{PO}_{3}$ Thermochim Acta 501:59-64.

[39] Ponomareva V, Lavrova G (2011) Controlling the proton transport properties of solid acids via structural and microstructural modification. J Solid State Electrochem 15(2): 213-221.

[40] Ponomareva VG, Shutova ES (2014) New medium-temperature proton electrolytes based on $\mathrm{CsH}_{2} \mathrm{PO}_{4}$ and silicophosphate matrices. Inorg Mater 50(10):1050-1056.

[41] Jensen AH, Li Q, Christensen E, Bjerrum NJ (2014) Intermediate Temperature Fuel Cell Using $\mathrm{CsH}_{2} \mathrm{PO}_{4} / \mathrm{ZrO}_{2}$-Based Composite Electrolytes. J Electrochem Soc 161(1):F72-F76.

[42] Xie Q, Li Y, Hu J, Chen X, Li H (2015) A CsH $\mathrm{PO}_{4}$-based composite electrolyte membrane for intermediate temperature fuel cells. J Membrane Science 489:98-105.

[43] Qing G, Kikuchi R, Takagaki A, Sugawara T, Oyama ST (2015) $\mathrm{CsH}_{2} \mathrm{PO}_{4} /$ Epoxy Composite Electrolytes for Intermediate Temperature Fuel Cells. Electrochim Acta 169:219-226.

[44] Mohammad N, Bakar Mohamad A, Kadhum AAH, Loh KS (2017) Effect of silica on the thermal behaviour and ionic conductivity of mixed salt solid acid composites, J Alloys and Compounds 690:896-902.

[45] Gupta LC, Rao URK, Venkateswarlu KS, Wani BR (1980) Thermal stability of $\mathrm{CsH}_{2} \mathrm{PO}_{4}$. Thermochim Acta 42(1):85-90.

[46] Taninouchi YK, Uda T, Awakura Y, Ikeda A, Haile SM (2007) Dehydration behavior of the superprotonic conductor $\mathrm{CsH}_{2} \mathrm{PO}_{4}$ at moderate temperatures: 230 to $260{ }^{\circ} \mathrm{C}$. J Mater Chem 17:3182-3189.

[47] Taninouchi YK, Uda T, Awakura $\mathrm{Y}$ (2008) Dehydration of $\mathrm{CsH}_{2} \mathrm{PO}_{4}$ at temperatures higher than $260{ }^{\circ} \mathrm{C}$ and the ionic conductivity of liquid product. Solid State lonics $178: 1648-1653$.

[48] Baranov Al, Kopnin EM, Grebenev VV, Sin A, Dubitsky Y, Caracino P (2009) Kinetics of the thermal decomposition in $\mathrm{CsH}_{2} \mathrm{PO}_{4}$ superprotonic crystal. Phys Status Solidi A 206(1):36-41.

[49] Bronowska W, Pietraszko A (1990) X-ray study of the high-temperature phase transition of $\mathrm{CsH}_{2} \mathrm{PO}_{4}$ crystals. Solid State Commun 76(3):293-298.

[50] Lee KS (1996) Hidden nature of the high-temperature transitions in crystals of $\mathrm{KH}_{2} \mathrm{PO}_{4}$-type: is it a physical change? J Phys Chem Solids 57(3):333-342. 
[51] Ortiz E, Vargas RA, Mellander BE (1999) On the high-temperature phase transitions of $\mathrm{CsH}_{2} \mathrm{PO}_{4}$ : a polymorphic transition? A transition to a superprotonic conducting phase? J Chem Phys 110(10):4847-4853.

[52] Ortiz E, Vargas RA, Mellander BE (1999) On the high-temperature phase transitions of some KDP-family compounds: A structural phase transition? A transition to a bulk-high proton conducting phase? Solid State lonics 125:177-185.

[53] Bronowska W (2001) Comment on "Does the structural superionic phase transition at $231{ }^{\circ} \mathrm{C}$ in $\mathrm{CsH}_{2} \mathrm{PO}_{4}$ in really not exist?" [J. Chem. Phys. 110, 4847 (1999)]. J Chem Phys 114(1):611-612.

[54] Park JH (2004) Possible origin of the proton conduction mechanism of $\mathrm{CsH}_{2} \mathrm{PO}_{4}$ crystals at high temperatures. Phys Rev B 69:054104-1-054104-6.

[55] Taninouchi YK, Hatada N, Uda T, Awakura Y (2009) Phase Relationship of $\mathrm{CsH}_{2} \mathrm{PO}_{4}-\mathrm{CsPO}_{3}$ System and Electrical Properties of $\mathrm{CsPO}_{3}$. J Electrochem Soc156(5):B572-B579.

[56] Hosseini S, Mohamad AB, Kadhum AH, Wan Daud WR (2010) Thermal analysis of $\mathrm{CsH}_{2} \mathrm{PO}_{4}$ nanoparticles using surfactants CTAB and F-68. J Therm Anal Calorim 99:197-202.

[57] Hosseini S, Daud WRW, Badiei M, Kadhum AAH, Mohammad AB (2011) Effect of surfactants in synthesis of $\mathrm{CsH}_{2} \mathrm{PO}_{4}$ as protonic conductive membrane. Bull Mater Sci 34(4):759-765.

[58] Hosseini S, Homaiee M, Mohamad AB, Malekbala MR, Khadum AAH (2011) Surfactant effect on the conductivity behavior of $\mathrm{CsH}_{2} \mathrm{PO}_{4}$ : Characterization by electrochemical impedance spectroscopy. Physica B 406:1689-1694.

[59] Papandrew AB, Chisholm CRI, Elgammal RA, Özer MM, Zecevic (SK 2011) Advanced Electrodes for Solid Acid Fuel Cells by Platinum Deposition on $\mathrm{CsH}_{2} \mathrm{PO}_{4}$. Chem Mater 23:16591667.

[60] Chee TH, Shyuan LK, Mohamad AB, Kadhum AAH (2011) $\mathrm{CsH}_{2} \mathrm{PO}_{4}$ : Electrolyte for Intermediate Temperature Fuel Cells. Adv Mater Res 239-242(3):2492-2498.

[61] Botez CE, Tackett RJ, Hermosillo JD, Zhang J, Zhao Y, Wang L (2012) High pressure synchrotron X-ray diffraction studies of superprotonic transitions in phosphate solid acids. Solid State lonics 213:58-62.

[62] Ortiz E, Piñeres I, León C (2016) On the low- to high proton-conducting transformation of a $\mathrm{CsHSO}_{4}-\mathrm{CsH}_{2} \mathrm{PO}_{4}$ solid solution and its parents. Physical or chemical nature? J Therm Anal Calorim 126:407-419.

[63] Takahashi H, Suzuki Y, Sakuma T (2016) New phase transition in superprotonic phase of inorganic solid acid $\mathrm{Cs}_{2}\left(\mathrm{HSO}_{4}\right)\left(\mathrm{H}_{2} \mathrm{PO}_{4}\right)$. Solid State lonics 285:155-159.

[64] Iwata Y, Koyano N, Shibuya I (1980) A Neutron Diffraction Study of the Ferroelectric Transition of $\mathrm{CsH}_{2} \mathrm{PO}_{4}$. J Phys Soc Jpn 49(1):304-307. 
[65] Nelmes RJ, Choudhary RNP (1978) Structural studies of the monoclinic dihydrogen phosphates: a neutron-diffraction study of paraelectric $\mathrm{CsH}_{2} \mathrm{PO}_{4}$. Solid State Comm 26:823-826.

[66] Matsunaga H, Itoh K, Nakamura E (1980) X-Ray Structural Study of Ferroelectric Cesium Dihydrogen Phosphate at Room Temperature. J Phys Soc Jpn 48:2011-2014.

[67] Lim AR, Lee KS (2015) Ferroelectric-Paraelectric Phase Transition of $\mathrm{CsH}_{2} \mathrm{PO}_{4}$ studied by Static NMR and MAS NMR. J Korean Magn Reson Soc 19:29-35.

[68] Yamada K, Sagara T, Yamane Y, Okuda HO (2004) Superprotonic conductor $\mathrm{CsH}_{2} \mathrm{PO}_{4}$ studied by ${ }^{1} \mathrm{H},{ }^{31} \mathrm{P}$ NMR and X-ray diffraction. Solid State lonics 175:557-562.

[69] Ikeda A, Kitchaev DA, Haile SM (2014) Phase behavior and superprotonic conductivity in the $\mathrm{Cs}_{1-\mathrm{x}} \mathrm{Rb}_{\mathrm{x}} \mathrm{H}_{2} \mathrm{PO}_{4}$ and $\mathrm{Cs}_{1-\mathrm{x}} \mathrm{K}_{\mathrm{x}} \mathrm{H}_{2} \mathrm{PO}_{4}$ systems. J Mater Chem A 2(1):204-214.

[70] Romain F, Novak A (1991) Raman study of the high-temperature phase transition in $\mathrm{CsH}_{2} \mathrm{PO}_{4}$. J Mol Struct 263:69-74.

[71] Ishikawa A, Maekawa H, Yamamura T, Kawakita Y, Shibata K, and Kawai M (2008) Proton dynamics of $\mathrm{CsH}_{2} \mathrm{PO}_{4}$ studied by quasi-elastic neutron scattering and PFG-NMR. Solid State Ionics 179:2345-2349.

[72] Lee HS, Tuckerman ME (2008) The Structure and Proton Transport Mechanisms in the Superprotonic Phase of $\mathrm{CsH}_{2} \mathrm{PO}_{4}$ : An Ab Initio Molecular Dynamics Study. J Phys Chem C 112(26):9917-9930.

[73] Kim G, Blanc F, Hu YY, Grey CP (2013) Understanding the Conduction Mechanism of the Protonic Conductor $\mathrm{CsH}_{2} \mathrm{PO}_{4}$ by Solid-State NMR Spectroscopy. J Phys Chem C 117(13):65046515.

[74] Kim G, Griffin JM, Blanc F, Haile SM, Grey CP (2015) Characterization of the Dynamics in the Protonic Conductor $\mathrm{CsH}_{2} \mathrm{PO}_{4}$ by ${ }^{17} \mathrm{O}$ Solid-State NMR Spectroscopy and First-Principles Calculations: Correlating Phosphate and Protonic Motion. J Am Chem Soc 137:3867-3876.

[75] Naïli H, Mhiri T, Daoud A (2000) Crystal structure, characterisation and vibrational study of a mixed compound $\mathrm{Cs}_{0.4} \mathrm{Rb}_{0.6} \mathrm{H}_{2} \mathrm{PO}_{4}$. Phase Trans 71:271-286.

[76] Naili H, Vendier L, Jaud J, Mhiri T (2001) The influence of partial substitution of phosphorus by arsenic in monoclinic $\mathrm{CsH}_{2} \mathrm{PO}_{4}$. X-ray single crystal, vibrational and phase transitions in the mixed $\mathrm{CsH}_{2}\left(\mathrm{PO}_{4}\right)_{0.72}(\mathrm{AsO} 4)_{0.28}$. Solid State Sciences 3(6):677-687.

[77] Lavrova GV, Burgina EB, Matvienko AA, Ponomareva VG (2006) Bulk and Surface Properties of lonic Salt $\mathrm{CsH}_{5}\left(\mathrm{PO}_{4}\right)_{2}$. Solid State lonics 177(13-14): 1117-1122.

[78] Lavrova GV, Shutova ES, Ponomareva VG, Dunyushkina LA (2013) Proton Conductivity and Interphase Interaction in $\mathrm{CsH}_{2} \mathrm{PO}_{4}-\mathrm{SrZrO}_{3}$ Composites. Russian J Electrochem 49(7):718-724. 
[79] Lavrova GV, Bulina NV, Min'kov VS, Matvienko AA (2016) Structure and Thermal Decomposition of $\mathrm{Cs}_{2} \mathrm{HPO}_{4} \cdot 2 \mathrm{H}_{2} \mathrm{O}$, Russian J Inorg Chem 61(3):284-290.

[80] Rodier M, Li Q, Berg RW, Bjerrum NJ (2016) Determination of Water Vapor Pressure Over Corrosive Chemicals Versus Temperature Using Raman Spectroscopy as Exemplified with 85.5\% Phosphoric Acid. Appl Spectrosc 70(7):1186-1194.

[81] Brühne $B$, Jansen $M$ (1993) Darstellung und Kristallstruktur von $\mathrm{Cs}_{8} \mathrm{P}_{8} \mathrm{O}_{24} 8 \mathrm{H}_{2} \mathrm{O}$ (in German). Z Anorg Allg Chem 619:1633-1638.

[82] Tordjman I, Masse R, Guitel JC (1977) Trimetaphosphate de cesium monohydrate (in French). Acta Cryst B 33:585-586.

[83] Liu C, Berg RW (2012) Nonlinearity in Intensity versus Concentration Dependence for the Deep UV Resonance Raman Spectra of Toluene and Heptane. Appl Spectrosc Rev 48(5):425437.

[84] Berg RW, Maijó Ferré I, Cline Schäffer SJ (2006) Raman spectroscopy evidence of 1:1:1 complex formation during dissolution of $\mathrm{WO}_{3}$ in a melt of $\mathrm{K}_{2} \mathrm{~S}_{2} \mathrm{O}_{7}: \mathrm{K}_{2} \mathrm{SO}_{4}$. Vib Spectrosc 42:346352.

[85] Liu C, Berg RW (2012) Determining the Spectral Resolution of a Charge-Coupled Device (CCD) Raman Instrument. Appl Spectrosc 66(9):1034-1043.

[86] Berg RW, Nørbygaard T (2006) Wavenumber Calibration of CCD Detector Raman Spectrometers Controlled by a Sinus Arm Drive. Appl Spectrosc Rev 41:165-183.

[87] Berg RW, von Winbush S, Bjerrum NJ (1980) Negative Oxidation States of the Chalcogenes in Molten Salts.1. Raman Spectroscopic Studies on Aluminum Chlorosulfides Formed in Chloride and Chloroaluminate Melts and Some Related Solid and Dissolved Compounds. Inorg Chem 19:26882698.

[88] Jones G, Bradshaw BC (1933) The measurement of the conductance of electrolytes. V. A redetermination of the conductance of standard potassium chloride solutions in absolute units. $J$ Am Chem Soc 55:1780-800.

[89] ASTM (2009) Standard Test Methods for Electrical Conductivity and Resistivity of Water, Designation: D1125-95 (Reapproved 2009). https://compass.astm.org/download/D112595R09.12192.pdf

[90] Berg RW, Hjuler HA, Bjerrum NJ (1985) Cryoscopy in the $\mathrm{KCl}-\mathrm{AlCl}_{3}$ system. High precision phase diagram near equimolar composition, with comments on oxide contaminations and effective chloride concentrations in tetrachloroaluminate melts. Inorg Chem 24:4506-4511.

[91] Hjuler HA, Berg RW, Zachariasen K, Bjerrum NJ (1985) Specific conductivity of $\mathrm{NaCl}-\mathrm{AlCl}_{3}$ and $\mathrm{NaCl}-\mathrm{AlCl}_{3}-\mathrm{Al}_{2} \mathrm{~S}_{3}$ melts. J Chem Eng Data 30:203-208. 
[92] Andreasen HA, Bjerrum NJ, Foverskov CE (1977) Automated "float" method for determination of densities of molten salts. Rev Sci Instrum 48:1340-1343.

[93] Nirsha BM, Gudinitsa EN, Fakeev AA, Efremov VA, Zhadanov BV, Olikova VA (1982) Thermal Dehydration Process of $\mathrm{CsH}_{2} \mathrm{PO}_{4}$ (in Russian). Zh Neorgan Khim 27(6):1366-1369.

[94] Bribes JL, Gaufrès R, Monan M, Lapp M, Penney CM (1976) Raman Band Contours for Water Vapor as a Function of Temperature. Appl Phys Letters 28:336-337.

[95] Penney CM, Lapp M (1976) Raman-Scattering Cross Sections for Water Vapor. J Opt Soc Am 66(5):422-425.

[96] Murphy WF (1978) The ro-vibrational Raman spectra of water vapour $v 1$ and $v 3$. Mol Phys 36 : 727-732.

[97] Schrötter HW, Klöckner HW (1979) Raman Scattering Cross Sections in Gas and Liquids. Topics in Current Physics, vol. 11. In: A. Weber (ed.) Raman Spectroscopy of Gases and Liquids. New York, Springer Verlag, pp.123-166.

[98] Schrötter HW (1995) Raman Spectra of Gasses. In: B. Schrader (ed.) Infrared and Raman Spectroscopy. Methods and Applications. Weinheim, Germany: Wiley VCH, pp. 277-296.

[99] Avila G, Fernández JM, Maté B, Tejeda G, Montero S (1999) Ro-vibrational Raman Cross Sections of Water Vapor in the OH Stretching Region. J Mol Spectrosc 196:77-92.

[100] Schrötter HW (2001) Raman Spectra of Gasses. In: I.R. Lewis, H.G.M. Edwards (eds.) Handbook of Raman Spectroscopy: From the Research Laboratory to the Process Line (Practical Spectroscopy). Boca Raton, FL: CRC Press, pp. 307-348.

[101] Hansen SB, Berg RW, Stenby EH (2001) High-Pressure Measuring Cell for Raman Spectroscopic Studies of Natural Gas. Appl Spectrosc 55(1):55-60.

[102] Lemmon EW, McLinden MO, Friend DG (1998) Thermophysical Properties of Fluid Systems. NIST Chemistry WebBook, NIST Standard Reference Database Number 69, Eds. P.J. Linstrom and W.G. Mallard, National Institute of Standards and Technology, Gaithersburg MD, 20899, doi:10.18434/T4D303, (retrieved August 16, 2017).

[103] Ikeda A, Haile SM (2012) The Thermodynamics and Kinetics of the Dehydration of $\mathrm{CsH}_{2} \mathrm{PO}_{4}$ Studied in the Presence of $\mathrm{SiO}_{2}$. Solid State lonics 213:63-71.

[104] Marchon B, Pasquier B, Le Calve N, Novak A, Čopič M, Zgonik M, Fox DL, Lavrenčič BB (1981) Infrared, Raman, and Brillouin spectra of $\mathrm{CsH}_{2} \mathrm{PO}_{4}$. J Chem Phys 74(10):5923-5924.

[105] Rumble S, Ninio F, Ti SS (1982) -OHO- vibrations in the Raman spectra of paraelectric $\mathrm{CsH}_{2} \mathrm{PO}_{4}$ crystal. Solid State Comm 42(11):767-771. 
[106] Ti SS, Rumble S, Ninio F (1982) Infrared spectra of paraelectric and ferroelectric $\mathrm{CsH}_{2} \mathrm{PO}_{4}$. Solid State Comm 44(2):129-135.

[107] Marchon B, Novak A (1983) Vibrational study of $\mathrm{CsH}_{2} \mathrm{PO}_{4}$ and $\mathrm{CsD}_{2} \mathrm{PO}_{4}$ single crystals. J Chem Phys 78(5):2105-2120.

[108] Kasahara M, Aoki M, Tatsuzaki I (1984) Raman study of the phase transition in $\mathrm{CsH}_{2} \mathrm{PO}_{4}$ and $\mathrm{CsD}_{2} \mathrm{PO}_{4}$. Ferroelectrics 55(1):47-50.

[109] Aoki M, Kasahara M, Tatsuzaki I (1984) Raman scattering study of $\mathrm{CsH}_{2} \mathrm{PO}_{4}$. J Raman Spectrosc. 15(2):97-102.

[110] Aoki M, Kasahara M, Tatsuzaki I (1985) Study of the phase transition of $\mathrm{CsD}_{2} \mathrm{PO}_{4}$ by Raman scattering. J Raman Spectrosc. 16(6):407-411.

[111] Choi BK, Lee MN, Kim JJ (1989) Raman spectra of the $\mathrm{NaH}_{2} \mathrm{PO}_{4}$ crystal. J Raman Spectrosc 20(1):11-15.

[112] Baranov Al, Grebenev VV, Khodan AN, Dolbinina VV, Efremova EP (2005) Optimization of superprotonic acid salts for fuel cell applications. Solid State lonics 176:2871-2874.

[113] Ponomareva VG, Shutova ES (2014) Electrical Conductivity and Structural Properties of Proton Electrolytes Based on $\mathrm{CsH}_{2} \mathrm{PO}_{4}$ and Silicophosphate Matrices with Low Phosphorus Content. Inorg Mater 50(10):1056-1062.

[114] Ponomareva VG, Lavrova GV (2017) Effect of the excess protons on the electrotransport, structural and thermodynamic properties of $\mathrm{CsH}_{2} \mathrm{PO}_{4}$. Solid State lonics 304:90-95.

[115] Martsinkevich VV, Ponomareva VG (2012) Double salts Cs1-xMxH2PO4 (M = Na, K, Rb) as proton conductors. Solid State Ionics 225(4):236-240.

[116] Hatori J, Matsuo Y, Ikehata S (2007) Proton conductivity and spontaneous strain below superprotonic phase transition in $\mathrm{CsH}_{2} \mathrm{PO}_{4}$. Solid State lonics 178:681-683.

[117] Vila J, Gin'es P, Pico JM, Franjo C, Jim'enez E, Varela LM, Cabeza O (2006) Temperature dependence of the electrical conductivity in EMIM-based ionic liquids Evidence of Vogel-TammanFulcher behavior. Fluid Phase Equilibria 242:141-146.

[118] Leys J, Wübbenhorst M, Menon CP, Rajesh R, Thoen J, Glorieux C, Nockemann P, Thijs B, Binnemans K, Longuemart S (2008) Temperature dependence of the electrical conductivity of imidazolium ionic liquids. J Chem Phys 128:064509, pp 1-7.

[119] Osterheld RK, Markowitz MM (1956) Polymerization and depolymerization phenomena in phosphate-metaphosphate systems at higher temperatures. 4. Condensation reactions of alkali metal hydrogen phosphates. J Phys Chem 60(7):863-867.

[120] Averbuch-Pouchot MT, Durif A (1992) Crystal structure of silver-dihydrogeno-diphospate: $\mathrm{Ag}_{2}$ $\mathrm{H}_{2} \mathrm{P}_{2} \mathrm{O}_{7}$. Eur J Sol State Inor 29:993-999. 
[121] Averbuch-Pouchot MT, Durif A (1993) Synthesis and crystal structure of cesium dihydrogen diphosphate. Comptes Rendus de l'Acad. des Sci. Paris 316(no.1, series II):41-46.

[122] Stoicheff BP (1957) High Resolution Raman Spectroscopy of gases IX. Spectra of $\mathrm{H}_{2}, \mathrm{HD}$ and $\mathrm{D}_{2}$. Canad J. Phys 35:730-741.

[123] Edwards HGM, Farwell DW, Gorvin AC, Long DA (1986) Pure Rotational and VibrationRotational Raman Spectra of ${ }^{1} \mathrm{H}_{2},{ }^{1} \mathrm{H}^{2} \mathrm{H}$ and ${ }^{2} \mathrm{H}_{2}$. J Raman Spectrosc 17:129-131.

[124] Petitpas G, Aceves SM, Matthews MJ, Smith JR (2014) Para- $\mathrm{H}_{2}$ to ortho- $\mathrm{H}_{2}$ conversion in a full-scale automotive cryogenic pressurized hydrogen storage up to 345 bar. Int J. Hydrogen Energy 39:6533-6547.

[125] Jennings DE, Weber A, Brault JW (1987) FTS-Raman Flame Spectroscopy of High-J Lines in $\mathrm{H}_{2}$ and $\mathrm{D}_{2}$. J Mol Spectrosc 126:19-28. 
Rapoport, 1978

\begin{tabular}{rr}
\multicolumn{3}{l}{ I-II interphase } \\
$X \quad{ }^{2} Y$ \\
0.24254 & 228.2727 \\
1.43657 & 231 \\
1.92164 & 233.8182 \\
3.48881 & 236.4546 \\
3.30224 & 238.6364 \\
5.89552 & 242.3636 \\
7.22015 & 247 \\
7.0709 & 248.8182 \\
7.74254 & 254.2727 \\
9.19776 & 254.2727 \\
9.12313 & 256.6364 \\
9.5709 & 258.4546 \\
11.10075 & 261.1818 \\
11.10075 & 263.3636
\end{tabular}

Liq-I interphase

$\begin{array}{rr}X & Y \\ X & 346.0909 \\ 2.25746 & 366.5455 \\ 1.97761 & 369.1818 \\ 3.69403 & 377.3636 \\ 4.5709 & 385.8182 \\ 5.52239 & 392.8182 \\ 6.25 & 391.6364 \\ 6.58582 & 393.8182 \\ 6.21269 & 396.5455 \\ 6.69776 & 402 \\ 8.60075 & 409.3636 \\ 8.22761 & 413.4546 \\ 8.69403 & 414.0909 \\ 9.29104 & 417.8182 \\ 9.8694 & 421.5455 \\ 10.29851 & 421.5455 \\ 11.77239 & 426.8182 \\ 11.66045 & 429.5455 \\ 12.14552 & 431.0909 \\ 12.42537 & 429.9091 \\ 12.89179 & 436.4546 \\ 13.28358 & 434 \\ 13.58209 & 438.3636 \\ 14.45896 & 436.9091 \\ 14.8694 & 435.4546 \\ 15.20522 & 441.2727 \\ 15.52239 & 439.0909\end{array}$

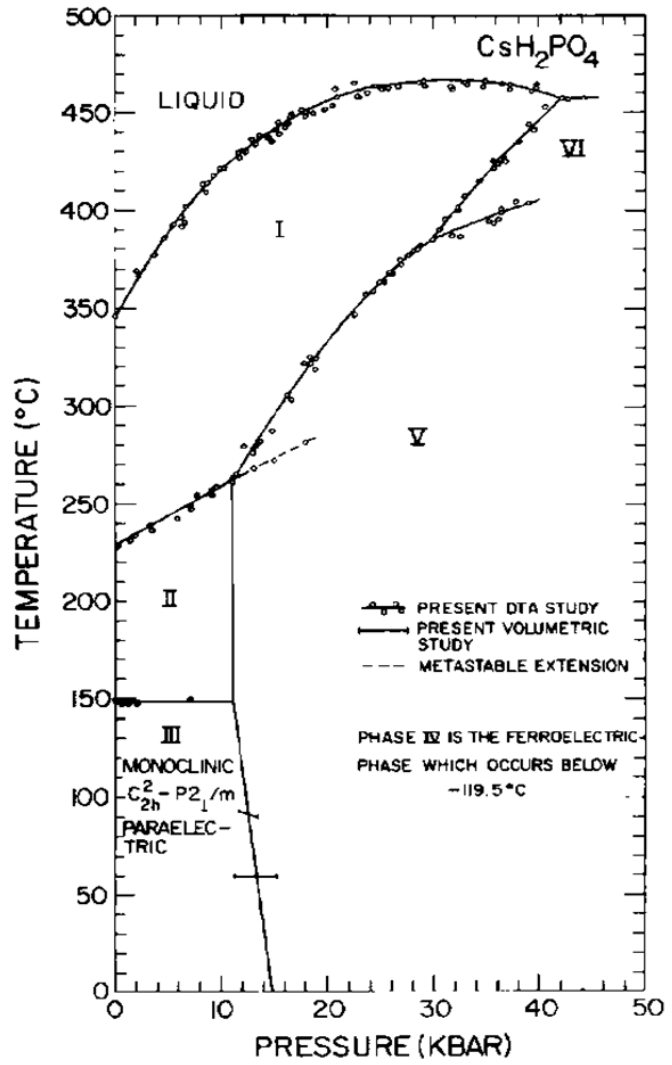

F1G. 4. The phase diagram of $\mathrm{CsH}_{2} \mathrm{PO}_{4}$ to $45 \mathrm{kbar}$. 
Data from this paper, Fig.10-11 1000/T log conductivity

1.61838

1.6129

1.60449

1.60346

1.60888

1.60862

1.61394

1.61303

1.61303

1.6129

1.61838

$1.61852-$

1.62404

1.62893

1.62866

1.62959

1.63599

1.64029

1.64568

1.65139

1.65673

1.66223

1.66764

1.67364

1.67912

1.68492

1.69047

1.69635

1.70213

1.70809

1.71394

1.71954

1.72577

1.7319

1.73792

1.74414

1.74993

1.75623

1.76196

1.76866

1.77525

1.78174

1.78779

1.7942

1.80083
$-0.87211$

$-0.60916$

$-0.6308$

$-0.62979$

$-0.63975$

$-0.64074$

$-0.64756$

$-0.64756$

$-0.65045$

$-0.65045$

$-0.65807$

$-0.66926$

$-0.67656$

$-1.07013$

$-1.09569$

$-1.11192$

$-1.12371$

$-1.13519$

$-1.14821$

$-1.15967$

$-1.17025$

$-1.18057$

$-1.19287$

$-1.20268$

$-1.21332$

$-1.22372$

$-1.23486$

$-1.24525$

$-1.25539$

$-1.26623$

$-1.2768$

$-1.28757$

$-1.29851$

$-1.30918$

$-1.32083$

$-1.33097$

$-1.34206$

$-1.35287$

$-1.3649$

$-1.37625$

$-1.38766$

$-1.39946$

$-1.41096$

$-1.42345$

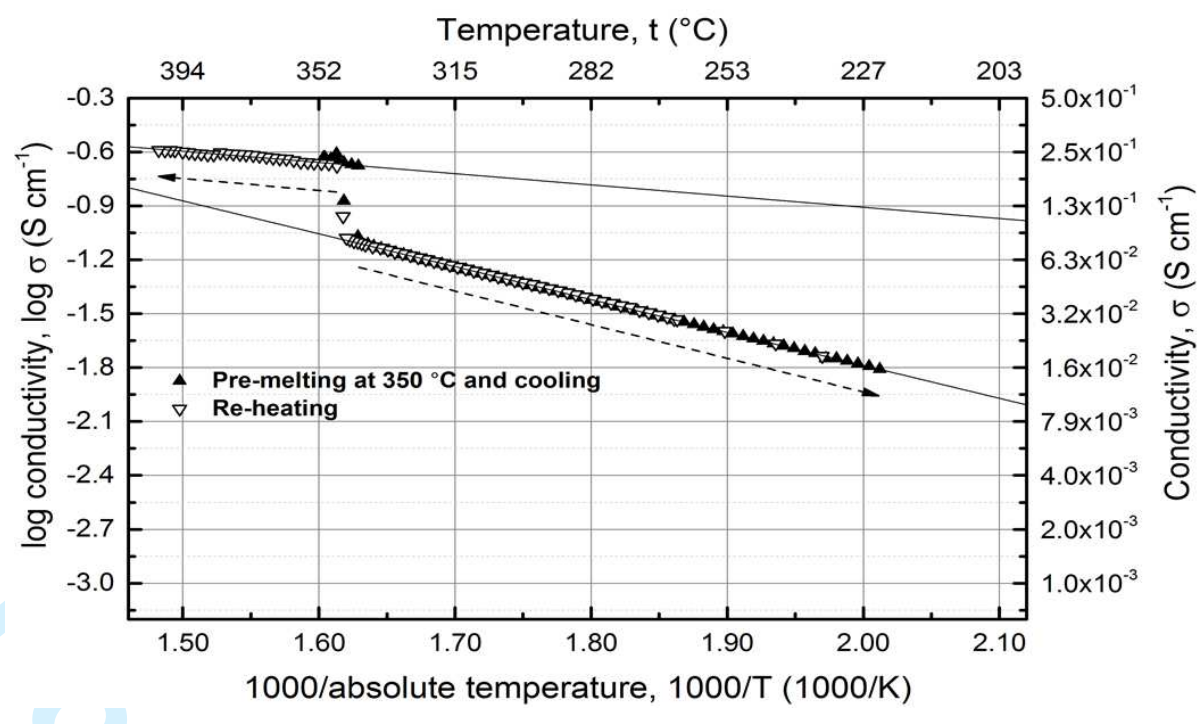

Ionics 


\begin{tabular}{|c|c|}
\hline 1.80734 & -1.43559 \\
\hline 1.81389 & -1.44679 \\
\hline 1.82083 & -1.45681 \\
\hline 1.82083 & -1.4601 \\
\hline 1.82749 & -1.47244 \\
\hline 1.83436 & -1.48499 \\
\hline 1.84111 & -1.49583 \\
\hline 1.84809 & -1.51013 \\
\hline 1.8546 & -1.52165 \\
\hline 1.86168 & -1.53439 \\
\hline 1.86846 & -1.54676 \\
\hline 1.87564 & -1.55974 \\
\hline 1.88271 & -1.57281 \\
\hline 1.89 & -1.58749 \\
\hline 1.89717 & -1.59846 \\
\hline 1.90422 & -1.61126 \\
\hline 1.91168 & -1.62472 \\
\hline 1.9192 & -1.63857 \\
\hline 1.9266 & -1.65199 \\
\hline 1.93405 & -1.66556 \\
\hline 1.94156 & -1.67908 \\
\hline 1.94913 & -1.69254 \\
\hline 1.95695 & -1.70796 \\
\hline 1.96464 & -1.72074 \\
\hline 1.97239 & -1.7489 \\
\hline 1.9802 & -1.74951 \\
\hline 1.98807 & -1.76336 \\
\hline 1.99601 & -1.77865 \\
\hline 2.00421 & -1.79286 \\
\hline 2.01207 & -1.80796 \\
\hline 2.02041 & -3.29634 \\
\hline 2.01654 & -3.29634 \\
\hline 2.00823 & -3.29634 \\
\hline 1.99402 & -3.29634 \\
\hline 1.97883 & -3.29634 \\
\hline 1.97883 & -3.29634 \\
\hline 2.0002 & -3.29634 \\
\hline 2.0014 & -3.29634 \\
\hline 2.0018 & -3.29634 \\
\hline 1.99322 & -3.29634 \\
\hline 1.97785 & -3.29634 \\
\hline 1.96967 & -1.73536 \\
\hline 1.96986 & -1.73631 \\
\hline 1.93555 & -1.66704 \\
\hline 1.89825 & -1.59716 \\
\hline 1.86098 & -1.53162 \\
\hline 1.86324 & -1.53263 \\
\hline
\end{tabular}

Ionics 


\begin{tabular}{|c|c|}
\hline 1.85598 & -1.51906 \\
\hline 1.84911 & -1.5064 \\
\hline 1.8423 & -1.49363 \\
\hline 1.83554 & -1.48132 \\
\hline 1.82849 & -1.46337 \\
\hline 1.82183 & -1.45471 \\
\hline 1.81472 & -1.44123 \\
\hline 1.80799 & -1.42988 \\
\hline 1.80148 & -1.41758 \\
\hline 1.79485 & -1.40559 \\
\hline 1.78875 & -1.3936 \\
\hline 1.78237 & -1.38199 \\
\hline 1.77573 & -1.37043 \\
\hline 1.76913 & -1.3593 \\
\hline 1.76243 & -1.34788 \\
\hline 1.75639 & -1.33655 \\
\hline 1.74993 & -1.32694 \\
\hline 1.74383 & -1.31712 \\
\hline 1.73807 & -1.30622 \\
\hline 1.73175 & -1.2946 \\
\hline 1.72563 & -1.28356 \\
\hline 1.71984 & -1.27315 \\
\hline 1.71394 & -1.26202 \\
\hline 1.7078 & -1.25059 \\
\hline 1.70184 & -1.24033 \\
\hline 1.69607 & -1.22983 \\
\hline 1.69019 & -1.21907 \\
\hline 1.68449 & -1.20963 \\
\hline 1.6787 & -1.1978 \\
\hline 1.67294 & -1.18732 \\
\hline 1.66722 & -1.17601 \\
\hline 1.66154 & -1.16558 \\
\hline 1.6559 & -1.15668 \\
\hline 1.65057 & -1.14515 \\
\hline 1.64514 & -1.13393 \\
\hline 1.63948 & -1.12757 \\
\hline 1.63399 & -1.1172 \\
\hline 1.63132 & -1.10926 \\
\hline 1.62866 & -1.10252 \\
\hline 1.62575 & -1.09775 \\
\hline 1.62285 & -1.08874 \\
\hline 1.62022 & -1.07953 \\
\hline 1.61773 & -0.9591 \\
\hline 1.61329 & -0.67836 \\
\hline 1.6072 & -0.66556 \\
\hline 1.60192 & -0.6637 \\
\hline 1.59655 & -0.66183 \\
\hline
\end{tabular}

Ionics 


$\begin{array}{rr}1.59172 & -0.65807 \\ 1.58655 & -0.65618 \\ 1.5814 & -0.64659 \\ 1.57604 & -0.63877 \\ 1.57109 & -0.63679 \\ 1.56629 & -0.6328 \\ 1.5614 & -0.62878 \\ 1.5563 & -0.62268 \\ 1.55171 & -0.61856 \\ 1.54655 & -0.61441 \\ 1.54202 & -0.61232 \\ 1.53704 & -0.61021 \\ 1.53221 & -0.6081 \\ 1.52765 & -0.60384 \\ 1.52765 & -0.60384 \\ 1.52277 & -0.61441 \\ 1.52277 & -0.61441 \\ 1.51826 & -0.61441 \\ 1.51343 & -0.61021 \\ 1.50898 & -0.6081 \\ 1.50444 & -0.60384 \\ 1.49993 & -0.59954 \\ 1.49432 & -0.59301 \\ 1.49098 & -0.59081 \\ 1.48699 & -0.59301 \\ 1.48236 & -0.59081\end{array}$




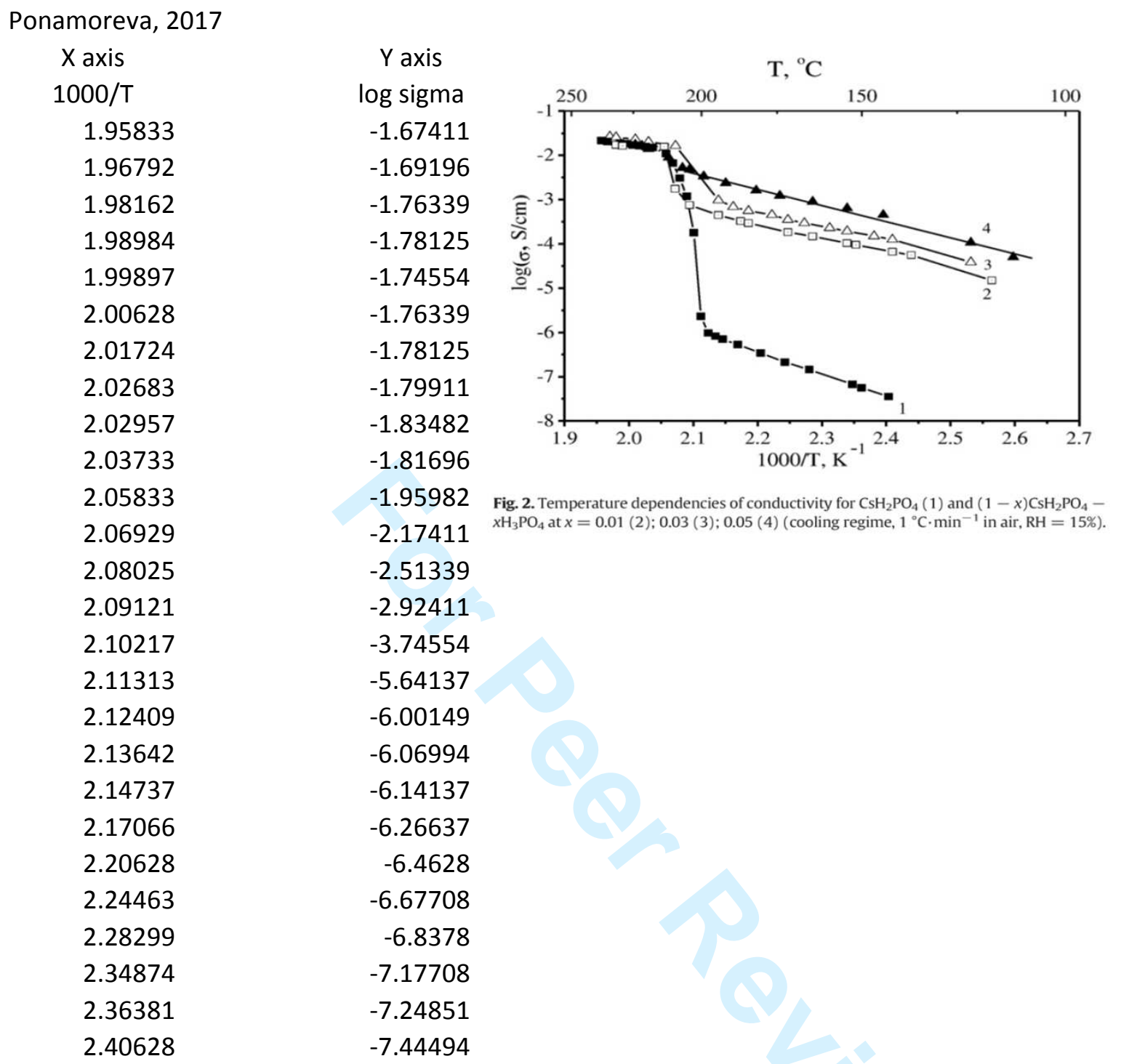


Qing, 2015

$X$ axis

1000/T

1.84363

1.8816

1.95118

2.0342

2.12005

2.21344

2.32123

2.43373

2.56439
Y axis

log sigma

$-1.57176$

$-1.63426$

$-1.75694$

$-2.75231$

$-3.62269$

$-4.0787$

$-4.3588$

$-4.56481$

$-4.53009$
Temperature $/{ }^{\circ} \mathrm{C}$

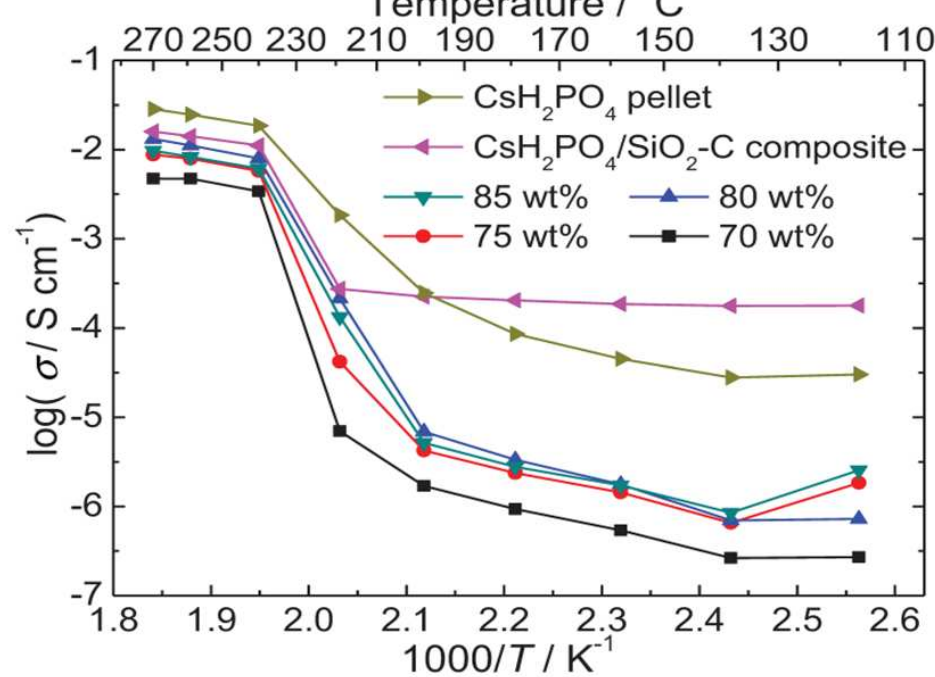

Fig. 7. Temperature dependence of the conductivity of a pure $\mathrm{CsH}_{2} \mathrm{PO}_{4}$ pellet electrolyte, $\mathrm{CsH}_{2} \mathrm{PO}_{4} / \mathrm{SiO}_{2}-\mathrm{C}$ composite electrolyte with $80 \mathrm{wt} \% \mathrm{CsH}_{2} \mathrm{PO}_{4}$, and the $\mathrm{CsH}_{2} \mathrm{PO}_{4} /$ epoxy composite electrolytes with different $\mathrm{CsH}_{2} \mathrm{PO}_{4}$ contents, under $30 \%$ $\mathrm{H}_{2} \mathrm{O} / \mathrm{Ar}$ atmosphere. 


$\begin{array}{cc}\begin{array}{c}\text { Jensen, } 2014 \\ \mathrm{X} \text { axis }\end{array} \\ 1000 / \mathrm{T} & \mathrm{Y} \text { axis } \\ 1.82468 & -2.68163 \\ 1.8417 & -2.33265 \\ 1.87617 & -2.09796 \\ 1.89362 & -2.05918 \\ 1.91191 & -2.01633 \\ 1.93021 & -2.08776 \\ 1.98426 & -5.53673 \\ 1.98766 & -5.57551 \\ 2.00851 & -5.66531 \\ 2.02809 & -5.75918 \\ 2.04936 & -5.84286 \\ 2.07021 & -5.93061 \\ 2.11489 & -6.09796 \\ 2.20681 & -6.47143 \\ 2.25702 & -6.62449\end{array}$

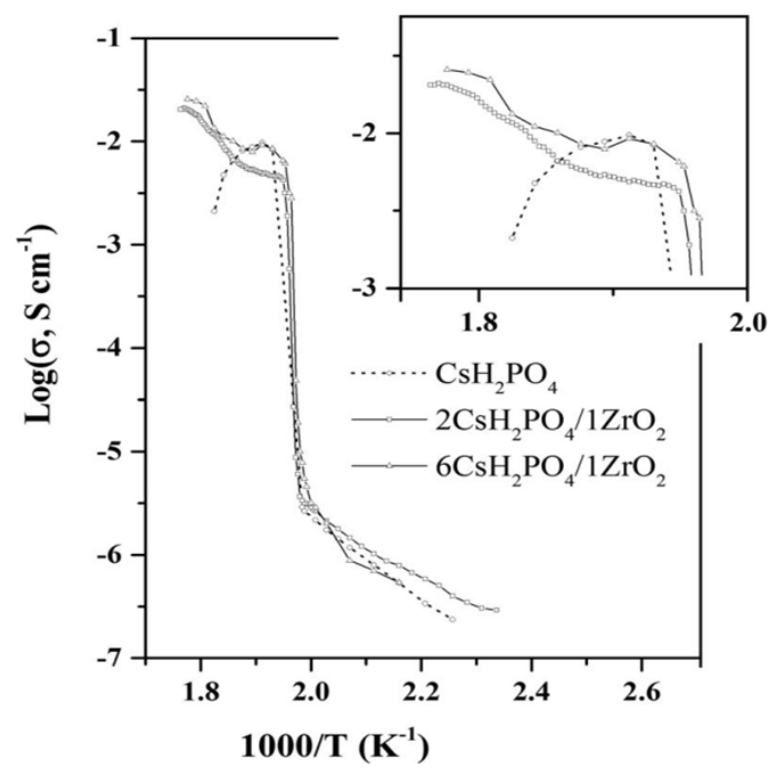

Figure 4. Temperature dependence of conductivity of $\mathrm{CsH}_{2} \mathrm{PO}_{4}$, $6 \mathrm{CsH}_{2} \mathrm{PO}_{4} / 1 \mathrm{ZrO}_{2}$ and $2 \mathrm{CsH}_{2} \mathrm{PO}_{4} / 1 \mathrm{ZrO}_{2}$ samples. Air was saturated with water at $50^{\circ} \mathrm{C}$. 
Ikeda, 2014

$\begin{array}{ccc}\mathrm{X} \text { axis } & \mathrm{Y} \text { axis } & \\ 1000 / \mathrm{T} & \text { sigma } & \text { log sigma } \\ 1.864 & 0.028 & -1.553 \\ 1.899 & 0.024 & -1.616 \\ 1.935 & 0.021 & -1.680 \\ 1.974 & 0.018 & -1.748 \\ 1.997 & 0.016 & -1.790 \\ 2.007 & 0.016 & -1.810 \\ 2.013 & 0.015 & -1.824\end{array}$

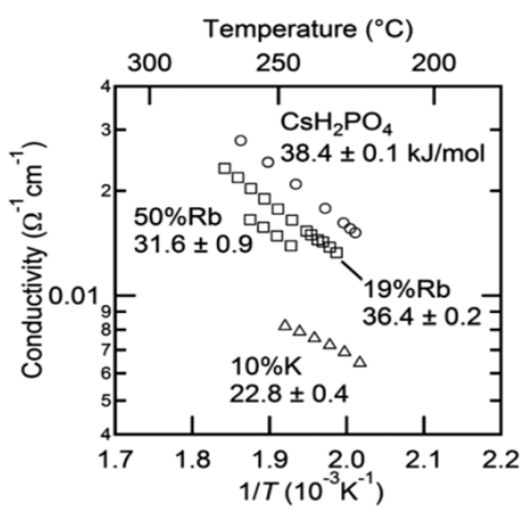

Fig. 15 Arrhenius representation of the conductivities of cubic $\mathrm{Cs}_{1-x} \mathrm{Rb}_{x} \mathrm{H}_{2} \mathrm{PO}_{4}$ and $\mathrm{Cs}_{1-x} \mathrm{~K}_{x} \mathrm{H}_{2} \mathrm{PO}_{4}$ as functions of temperature. 


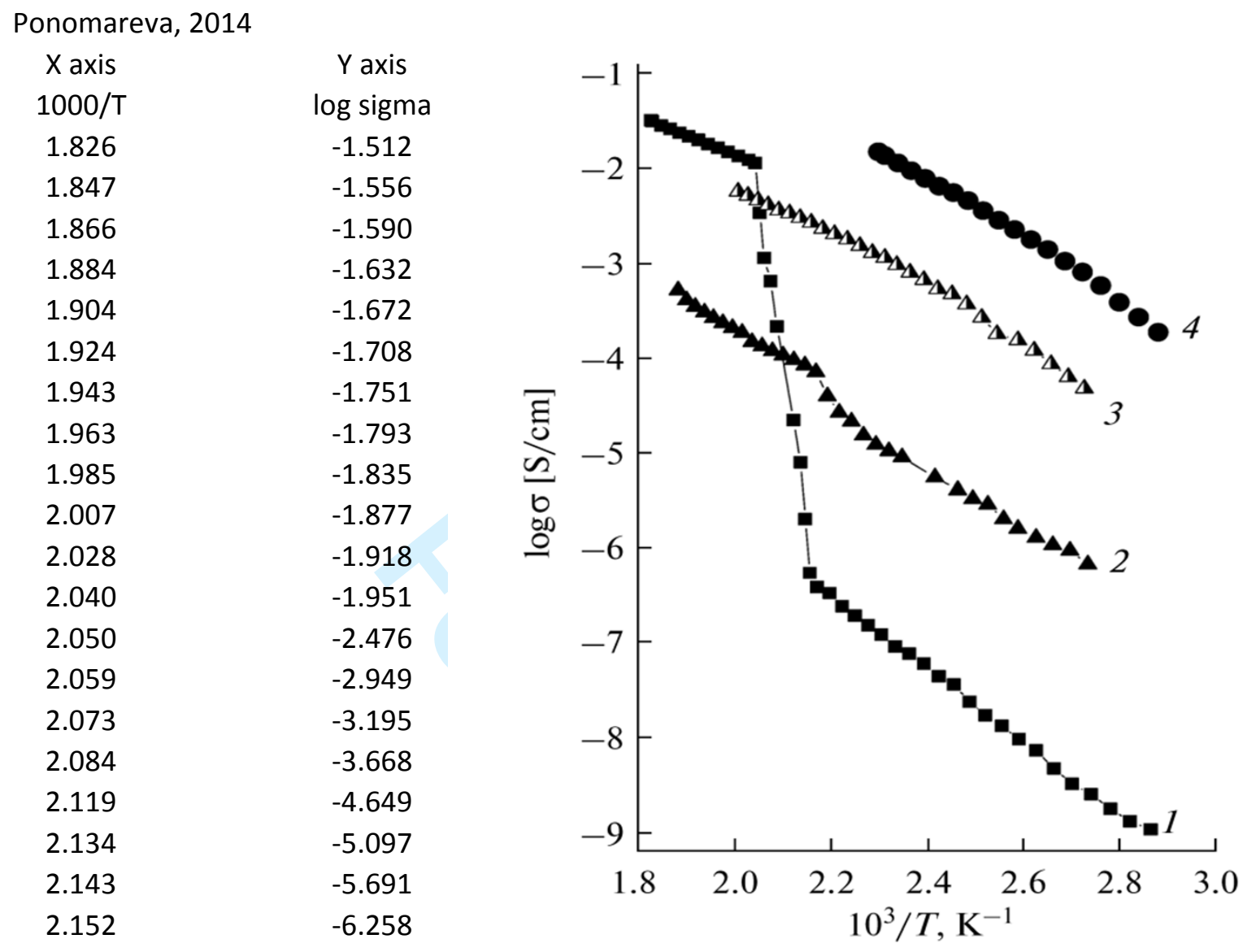

$2.167-6.410$

$2.193-6.476$

$2.218-6.613$

$2.244-6.715$

$2.272-6.816$

$2.299-6.909$

$2.327-7.036$

$2.356 \quad-7.112$

$2.387-7.220$

$2.417-7.355$

$2.448 \quad-7.433$

$2.481 \quad-7.611$

$2.512-7.761$

$2.547-7.865$

$2.582 \quad-8.008$

$2.617-8.127$

$2.653-8.319$

$2.690 \quad-8.480$

$2.729-8.590$

$2.769-8.742$

$2.810 \quad-8.871$

$2.852 \quad-8.956$

Fig. 8. Arrhenius plots of conductivity for (1) $\mathrm{CsH}_{2} \mathrm{PO}_{4}$ and $\mathrm{CsH}_{2} \mathrm{PO}_{4}-\mathrm{A}$ composites: $\mathrm{A}=$ (2) $\mathrm{SiO}_{2}$ [8], (3) $\mathrm{SiO}_{2}-$ $0.07 \mathrm{P}_{2} \mathrm{O}_{5}$, and (4) $\mathrm{SiO}_{2}-0.25 \mathrm{P}_{2} \mathrm{O}_{5}$ [9] (relative humidity of $0.6 \mathrm{~mol} \mathrm{\%} \mathrm{H}_{2} \mathrm{O}$ ). 


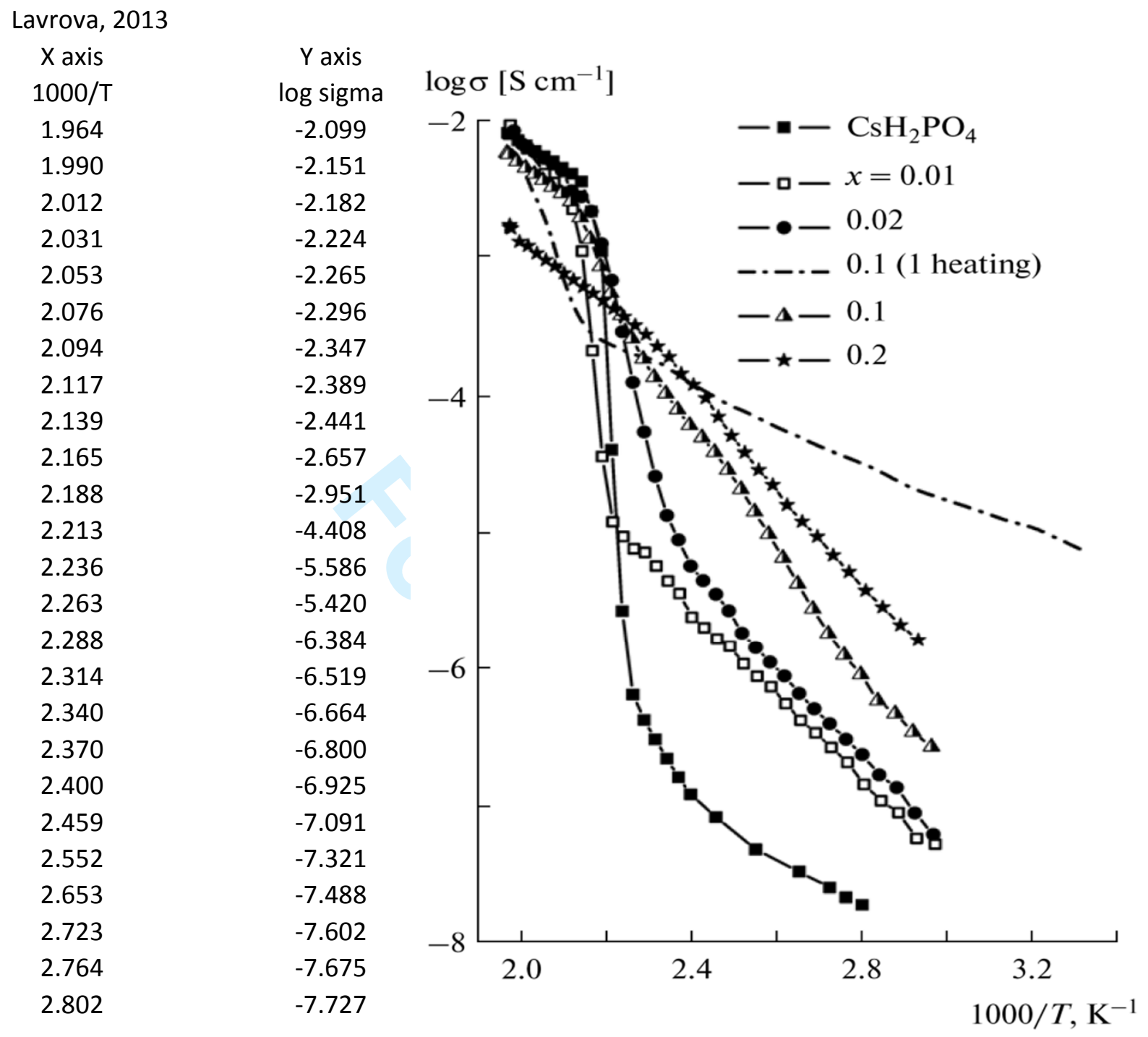

Fig. 1. Temperature dependences of conductivity of the $(1-x) \mathrm{CsH}_{2} \mathrm{PO}_{4}-x \mathrm{SrZrO}_{3}$ composites with different composition; the healing mode; $2^{\circ} \mathrm{C} / \mathrm{min}$; air. For comparison, the data for the first heating of the $0.9 \mathrm{CsH}_{2} \mathrm{PO}_{4}-$ $0.1 \mathrm{SrZrO}_{3}$ sample are shown. 


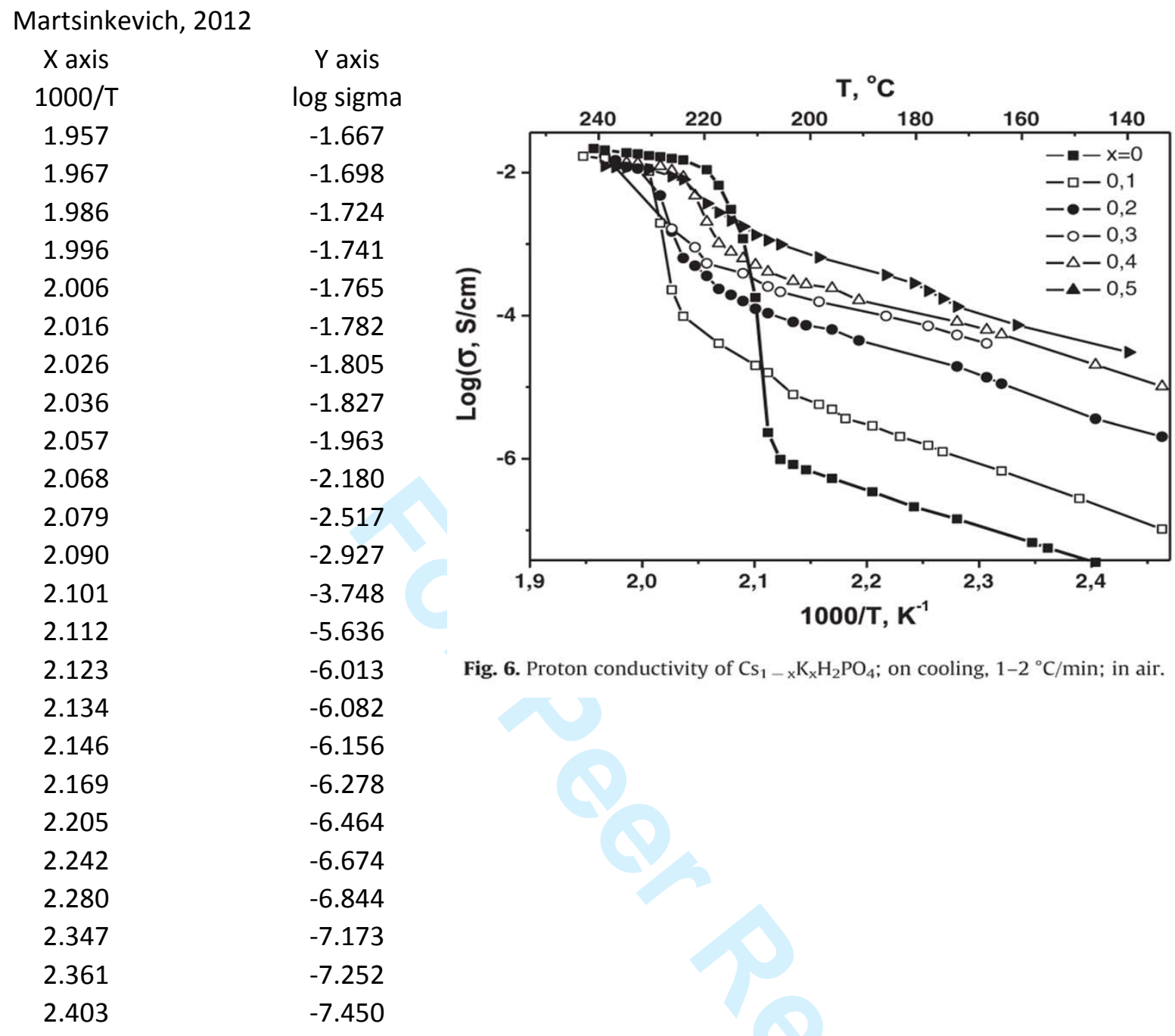




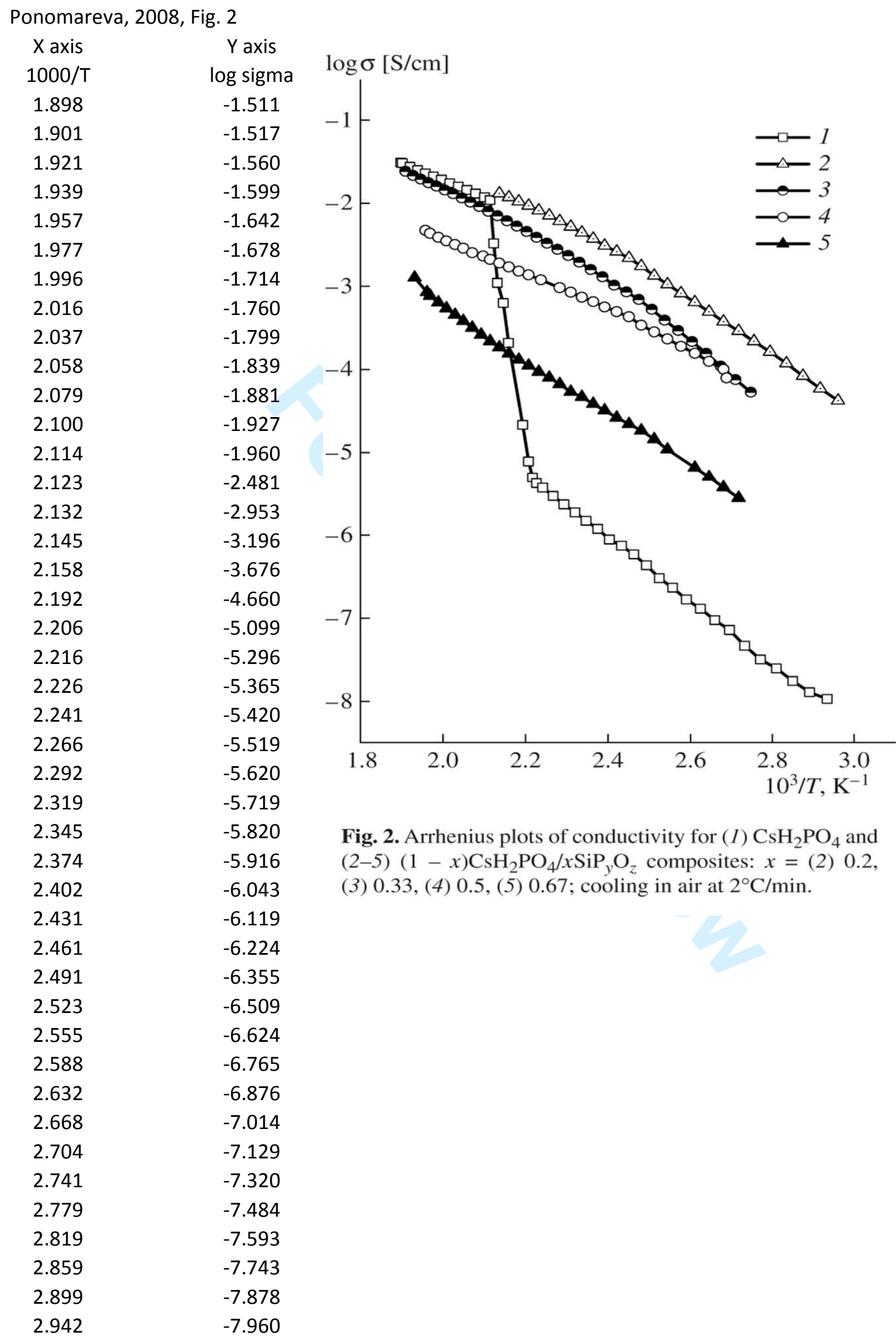

Ionics 
Ponomareva, 2008, Fig. 3

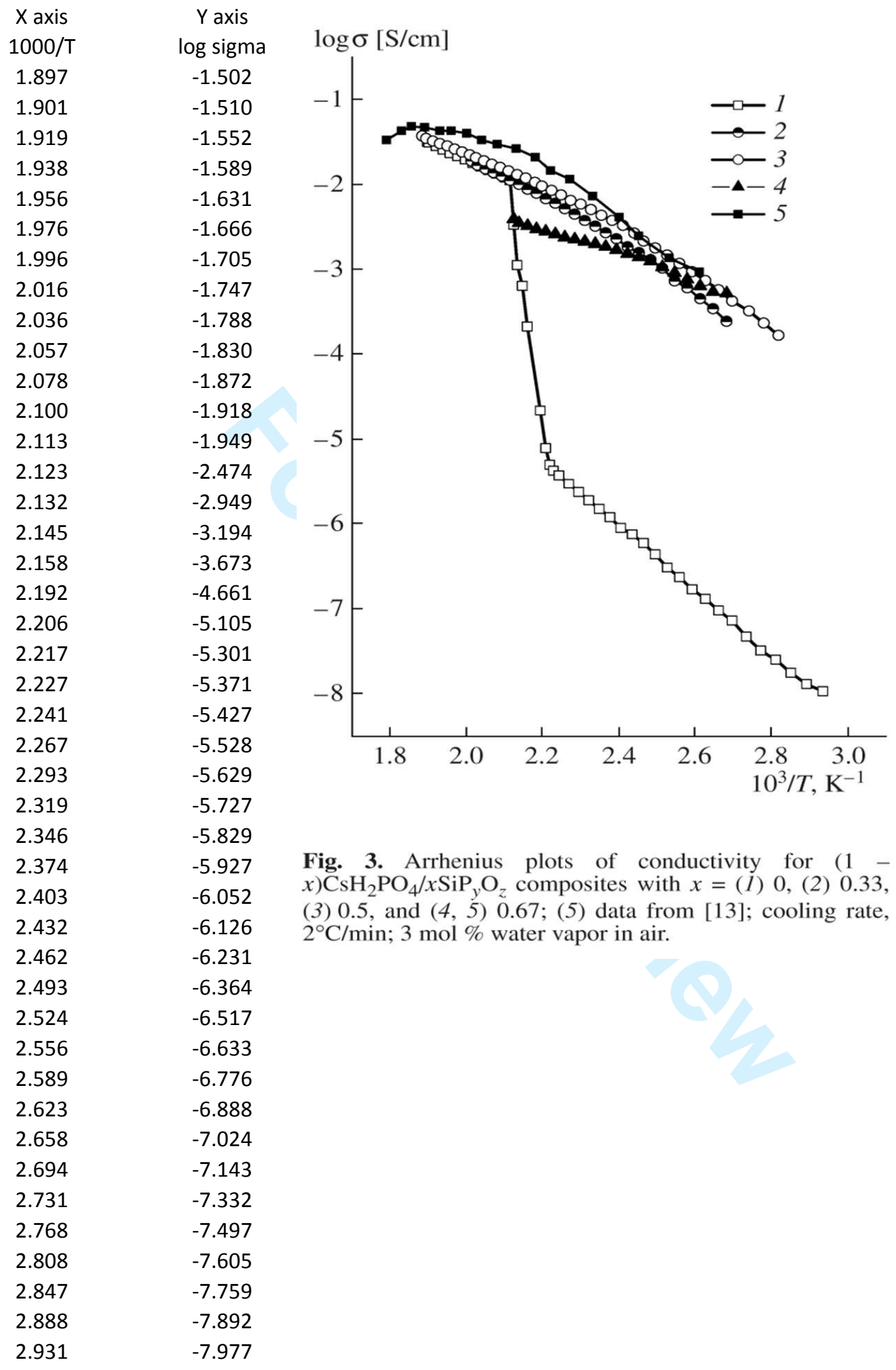

Ionics 


\begin{tabular}{|c|c|c|c|c|c|}
\hline \multicolumn{6}{|c|}{ Ponomareva, 2008, Fig. 3} \\
\hline $\mathrm{X}$ axis & $\mathrm{Y}$ axis & & & & \\
\hline $1000 / T$ & $\log$ sigma $T$ & $\mathrm{~T}$ & $\log T$ & log sigma & 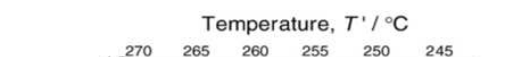 \\
\hline 1.869 & 0.763 & 535.011 & 2.728 & -1.965 & 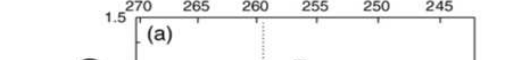 \\
\hline 1.871 & 0.911 & 534.377 & 2.728 & -1.816 & $\alpha_{0}^{T_{\text {denty }}}$ \\
\hline 1.873 & 1.062 & 533.774 & 2.727 & -1.666 & $\begin{array}{ll}E^{5} \\
\omega_{1.0}\end{array}$ \\
\hline 1.876 & 1.141 & 533.183 & 2.727 & -1.586 & ०. \\
\hline 1.878 & 1.165 & 532.503 & 2.726 & -1.561 & $\begin{array}{l}\quad-\quad \mathrm{H}_{2} \mathrm{O}=0.18 \mathrm{~atm} \\
\text { Heating rate }=1.2 \mathrm{~K} \mathrm{hr}^{-1}\end{array}$ \\
\hline 1.880 & 1.163 & 531.965 & 2.726 & -1.562 & $\begin{array}{lllll}0.5 & 1.84 & 1.86 & 1.88 & 1.90 \\
1000 / T & / .92 & 1.94 \\
\end{array}$ \\
\hline 1.882 & 1.157 & 531.368 & 2.725 & -1.568 & Temperature, $T^{\prime} /{ }^{\circ} \mathrm{C}$ \\
\hline 1.884 & 1.153 & 530.772 & 2.725 & -1.572 & 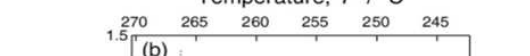 \\
\hline 1.886 & 1.149 & 530.266 & 2.724 & -1.576 & $\mp \mid(b)$ \\
\hline 1.888 & 1.145 & 529.525 & 2.724 & -1.579 & $\begin{array}{l}E \\
\text { E } \\
\text { O }\end{array}$ \\
\hline 1.890 & 1.140 & 528.963 & 2.723 & -1.584 & \\
\hline 1.893 & 1.134 & 528.235 & 2.723 & -1.588 & $p \mathrm{H}_{2} \mathrm{O}=0.23 \mathrm{~atm}$ \\
\hline 1.895 & 1.131 & 527.842 & 2.723 & -1.591 & 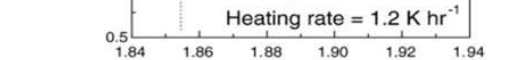 \\
\hline 1.897 & 1.125 & 527.195 & 2.722 & -1.597 & 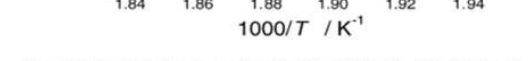 \\
\hline 1.899 & 1.121 & 526.560 & 2.721 & -1.600 & 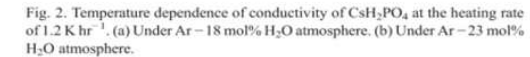 \\
\hline 1.901 & 1.117 & 525.994 & 2.721 & -1.604 & \\
\hline 1.903 & 1.114 & 525.410 & 2.720 & -1.606 & \\
\hline 1.906 & 1.110 & 524.769 & 2.720 & -1.610 & \\
\hline 1.908 & 1.106 & 524.227 & 2.720 & -1.614 & \\
\hline 1.909 & 1.103 & 523.763 & 2.719 & -1.617 & \\
\hline 1.911 & 1.098 & 523.165 & 2.719 & -1.620 & \\
\hline 1.914 & 1.093 & 522.395 & 2.718 & -1.625 & \\
\hline 1.916 & 1.090 & 521.857 & 2.718 & -1.628 & \\
\hline 1.918 & 1.086 & 521.340 & 2.717 & -1.632 & \\
\hline 1.920 & 1.081 & 520.795 & 2.717 & -1.636 & \\
\hline 1.922 & 1.076 & 520.232 & 2.716 & -1.640 & \\
\hline 1.925 & 1.072 & 519.557 & 2.716 & -1.644 & \\
\hline 1.927 & 1.068 & 519.015 & 2.715 & -1.647 & \\
\hline 1.929 & 1.064 & 518.381 & 2.715 & -1.650 & \\
\hline 1.931 & 1.060 & 517.851 & 2.714 & -1.654 & \\
\hline 1.934 & 1.054 & 517.106 & 2.714 & -1.659 & \\
\hline 1.936 & 1.051 & 516.467 & 2.713 & -1.662 & \\
\hline 1.938 & 1.047 & 516.026 & 2.713 & -1.665 & \\
\hline
\end{tabular}




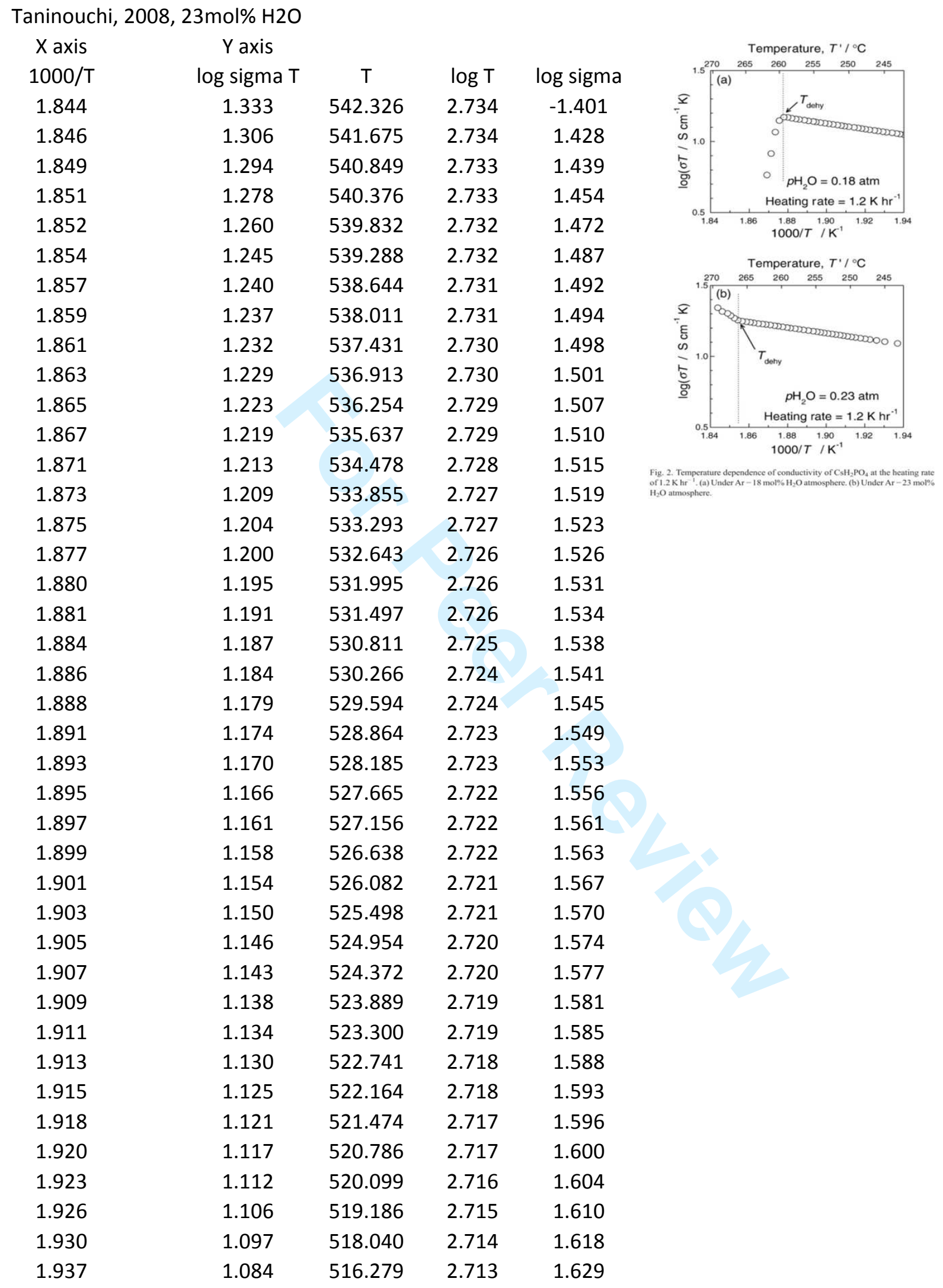




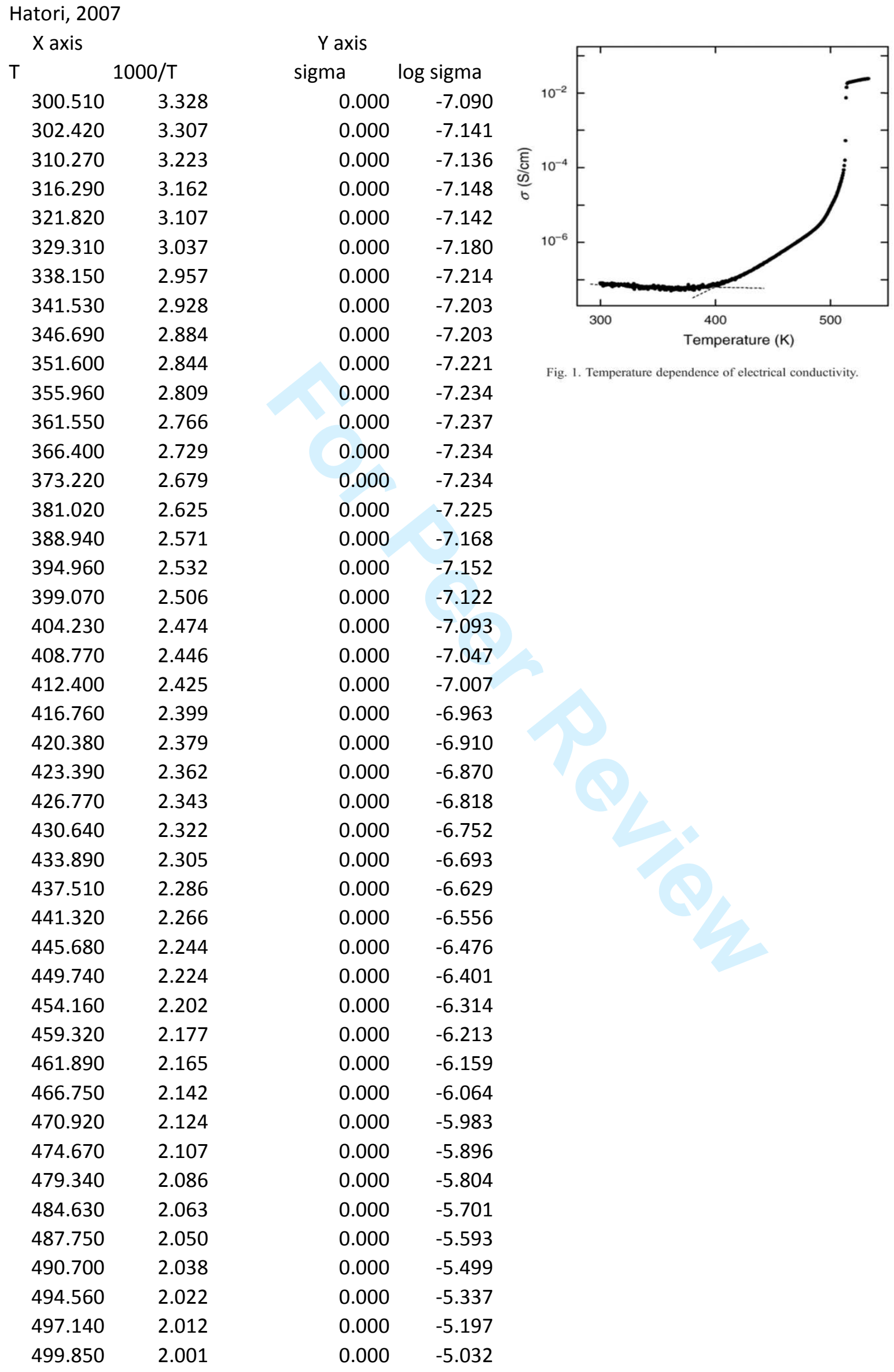




$\begin{array}{llll}502.860 & 1.989 & 0.000 & -4.851 \\ 505.930 & 1.977 & 0.000 & -4.636 \\ 507.280 & 1.971 & 0.000 & -4.503 \\ 508.630 & 1.966 & 0.000 & -4.371 \\ 509.790 & 1.962 & 0.000 & -4.241 \\ 511.270 & 1.956 & 0.000 & -4.040 \\ 511.640 & 1.954 & 0.000 & -3.932 \\ 512.130 & 1.953 & 0.000 & -3.790 \\ 512.620 & 1.951 & 0.001 & -3.271 \\ 513.110 & 1.949 & 0.008 & -2.119 \\ 513.470 & 1.948 & 0.015 & -1.839 \\ 514.220 & 1.945 & 0.019 & -1.730 \\ 517.160 & 1.934 & 0.020 & -1.694 \\ 520.360 & 1.922 & 0.021 & -1.678 \\ 523.730 & 1.909 & 0.022 & -1.652 \\ 527.300 & 1.896 & 0.023 & -1.630 \\ 530.120 & 1.886 & 0.024 & -1.614 \\ 533.008 & 1.876 & 0.025 & -1.604\end{array}$


Muroyama, 2007

$\begin{array}{cc}X \text { axis } & Y \text { axis } \\ 1000 / T & \text { log sigma } \\ 1.824 & -1.463 \\ 1.889 & -1.594 \\ 1.956 & -1.704 \\ 2.026 & -4.665 \\ 2.099 & -4.776 \\ 2.181 & -4.804 \\ 2.271 & -4.886 \\ 2.360 & -4.984 \\ 2.477 & -5.086 \\ 2.599 & -5.204\end{array}$

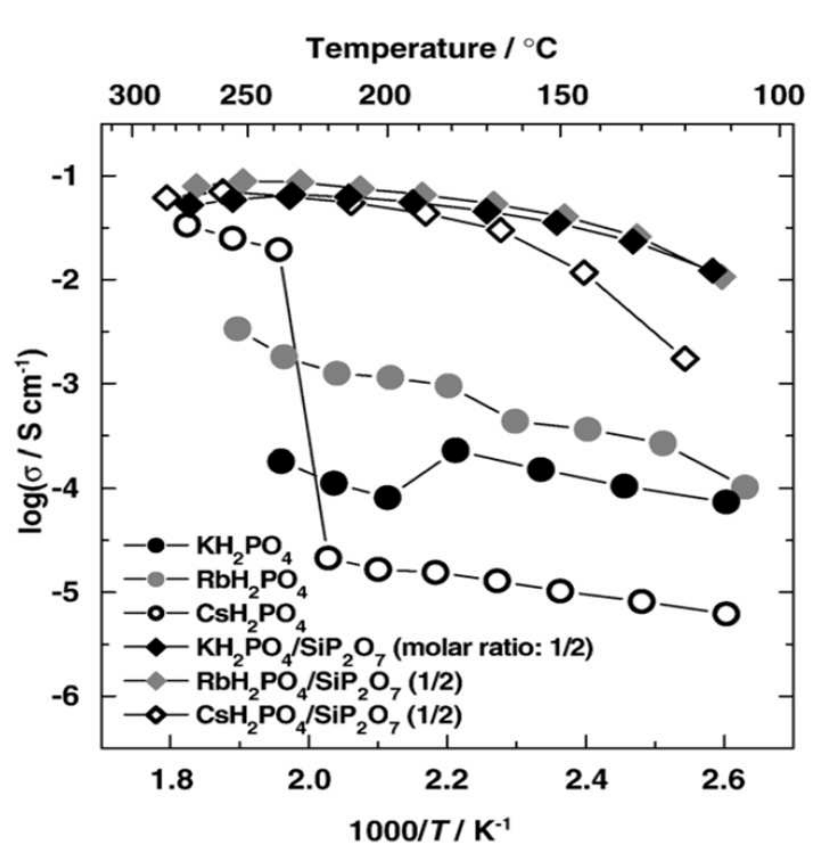

Fig. 3. Temperature dependence of the conductivity for $\mathrm{MH}_{2} \mathrm{PO}_{4}$ and $\mathrm{MH}_{2} \mathrm{PO}_{4}$ / $\mathrm{SiP}_{2} \mathrm{O}_{7}$-based composites (molar ratio: $1 / 2, \mathrm{M}=\mathrm{K}, \mathrm{Rb}, \mathrm{Cs}$ ) under $30 \% \mathrm{H}_{2} \mathrm{O} / \mathrm{Ar}$ atmosphere in the heating process. 


\begin{tabular}{cc}
$\begin{array}{c}\text { Ponomareva, } 2007 \\
X \text { axis }\end{array}$ & $Y$ Y axis \\
$1000 / T$ & log sigma \\
1.909 & -1.879 \\
1.915 & -1.898 \\
1.934 & -1.944 \\
1.954 & -1.972 \\
1.971 & -1.991 \\
1.990 & -2.019 \\
2.032 & -2.028 \\
2.052 & -2.056 \\
2.074 & -2.092 \\
2.113 & -2.138 \\
2.141 & -2.269 \\
2.155 & -2.464 \\
2.163 & -2.707 \\
2.174 & -3.079 \\
2.186 & -3.452 \\
2.200 & -4.363 \\
2.211 & -4.932 \\
2.222 & -5.435 \\
2.236 & -5.759 \\
2.262 & -5.862 \\
2.286 & -5.927 \\
2.314 & -6.280 \\
2.325 & -6.318 \\
2.340 & -6.368 \\
2.356 & -6.411 \\
2.368 & -6.458 \\
2.379 & -6.495 \\
2.398 & -6.522 \\
2.414 & -6.531 \\
& \\
\hline &
\end{tabular}

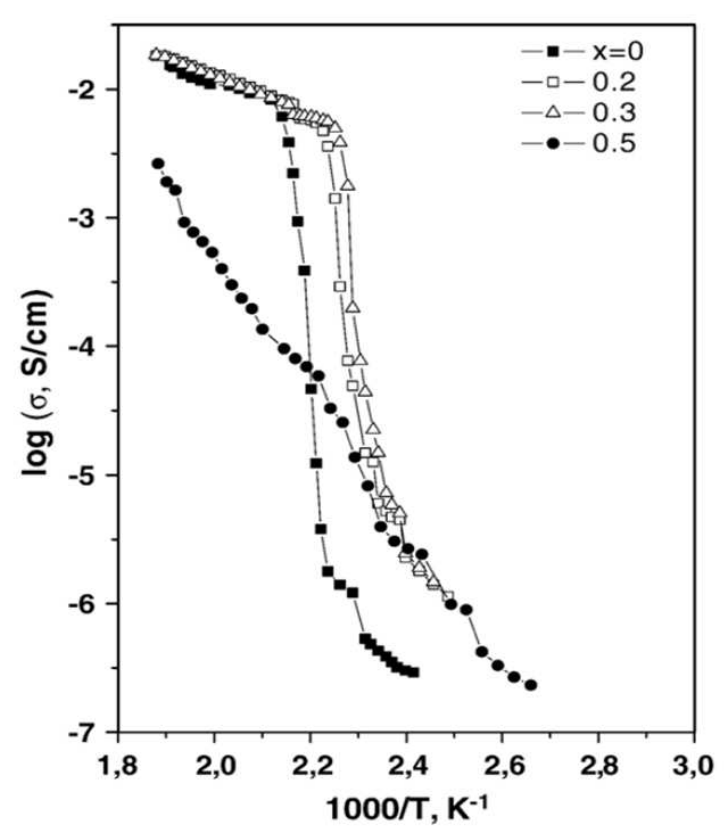

Fig. 1. The temperature dependencies of the conductivity of polycrystalline $\mathrm{CsH}_{2} \mathrm{PO}_{4}$ and $(1-x) \mathrm{CsH}_{2} \mathrm{PO}_{4}-x \mathrm{SiO}_{2}$ composites with different $\mathrm{SiO}_{2}$ content ( $S_{\mathrm{sp}}=300 \mathrm{~m}^{2} / \mathrm{g}$, cooling regime $2 \mathrm{~K} / \mathrm{min}, \mathrm{H}_{2} \mathrm{O}$ partial pressure $\sim 0.6 \mathrm{~mol} \%$ in air). 
Haile, 2006-2007

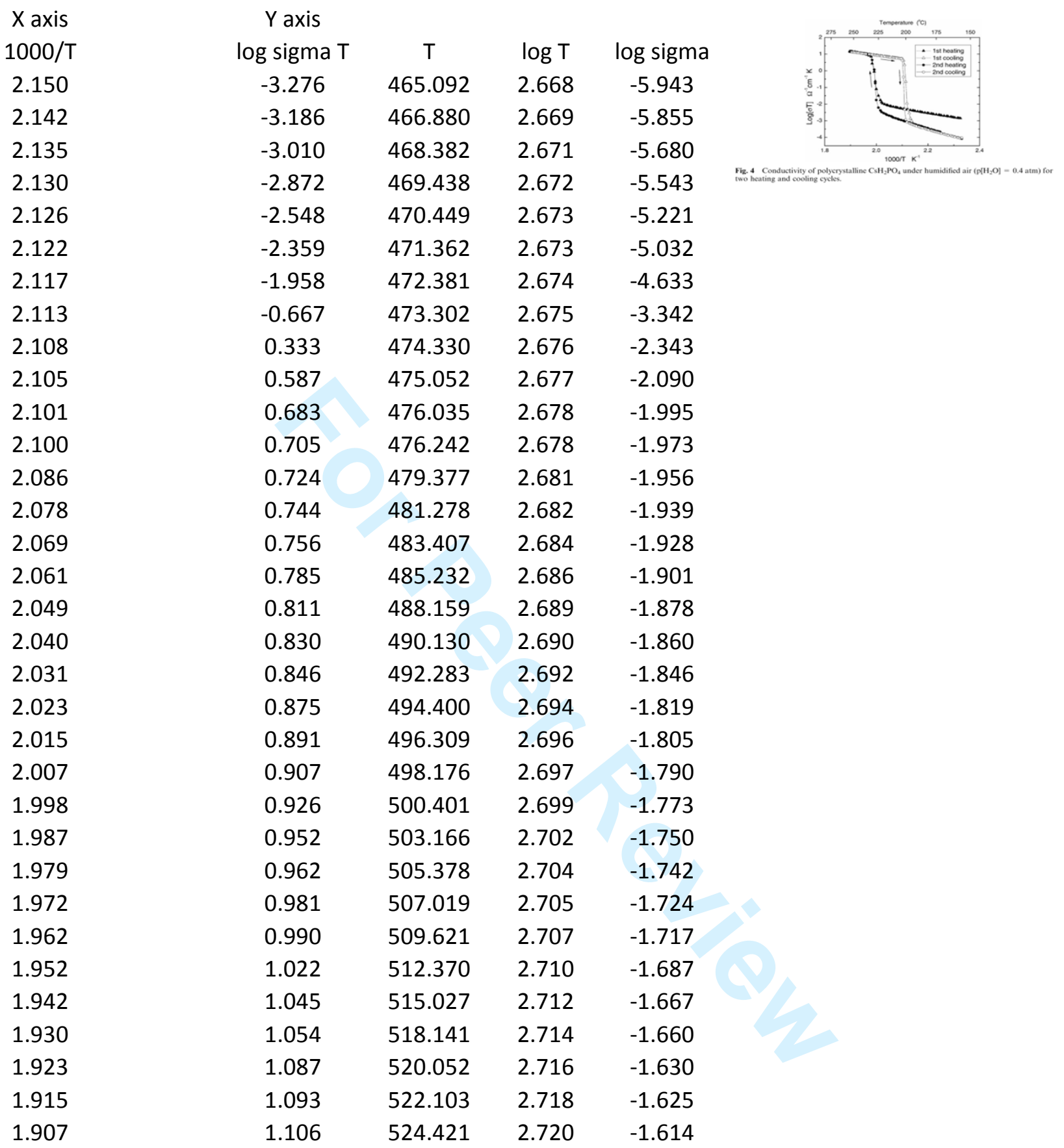




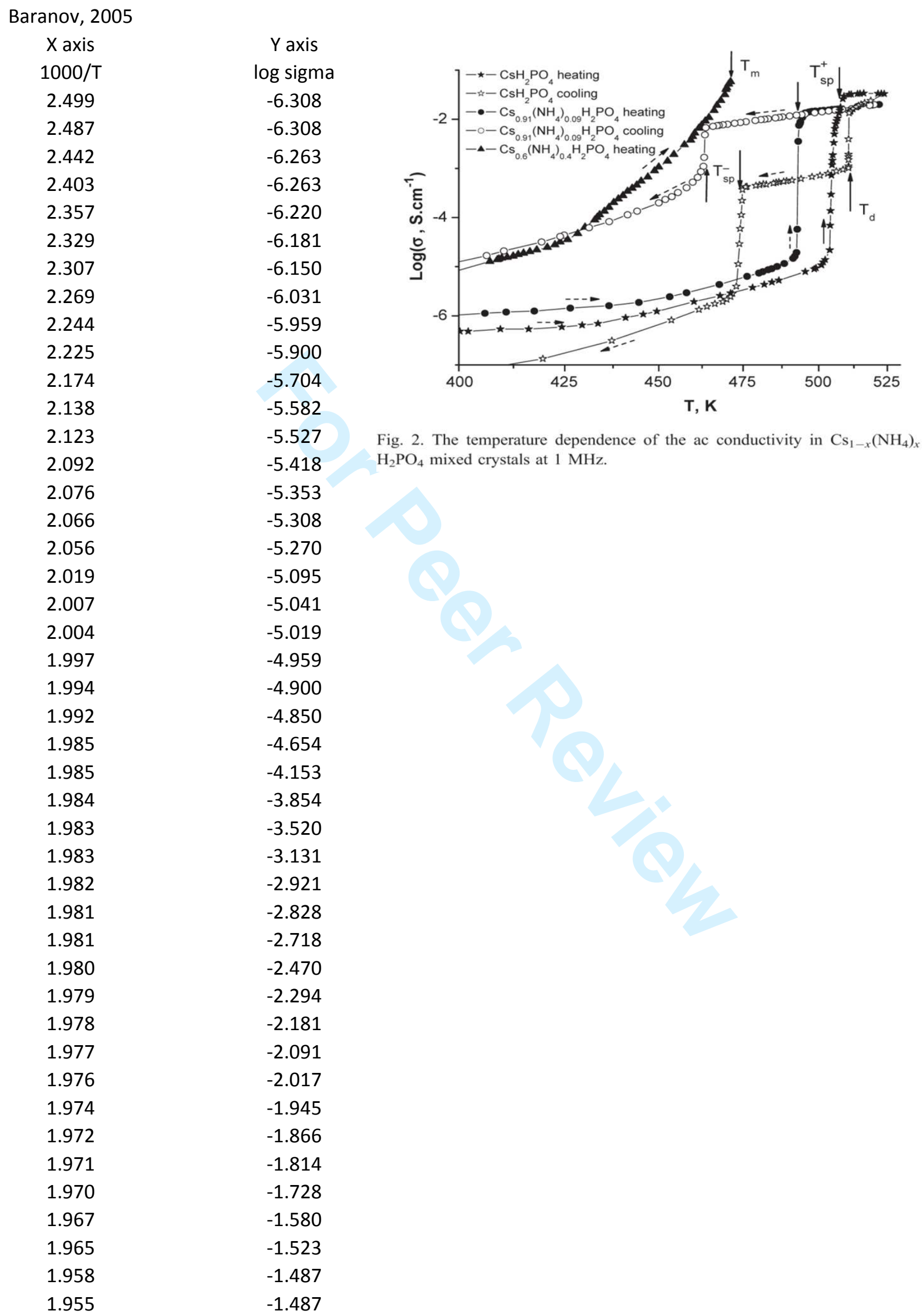

Ionics 


\begin{tabular}{|c|c|}
\hline 1.947 & -1.473 \\
\hline 1.943 & -1.470 \\
\hline 1.938 & -1.463 \\
\hline 1.918 & -1.470 \\
\hline 1.914 & -1.470 \\
\hline 1.910 & -1.473 \\
\hline 1.928 & -1.613 \\
\hline 1.937 & -1.659 \\
\hline 1.942 & -1.690 \\
\hline 1.945 & -1.716 \\
\hline 1.949 & -1.747 \\
\hline 1.953 & -1.785 \\
\hline 1.957 & -1.835 \\
\hline 1.958 & -1.866 \\
\hline 1.959 & -2.396 \\
\hline 1.959 & -2.706 \\
\hline 1.959 & -2.752 \\
\hline 1.959 & -2.816 \\
\hline 1.959 & -2.943 \\
\hline 1.959 & -2.986 \\
\hline 1.967 & -3.017 \\
\hline 1.976 & -3.048 \\
\hline 1.988 & -3.095 \\
\hline 1.999 & -3.136 \\
\hline 2.010 & -3.162 \\
\hline 2.025 & -3.203 \\
\hline 2.037 & -3.234 \\
\hline 2.045 & -3.248 \\
\hline 2.049 & -3.258 \\
\hline 2.056 & -3.270 \\
\hline 2.059 & -3.279 \\
\hline 2.063 & -3.294 \\
\hline 2.073 & -3.317 \\
\hline 2.077 & -3.310 \\
\hline 2.082 & -3.329 \\
\hline 2.088 & -3.341 \\
\hline 2.100 & -3.363 \\
\hline 2.102 & -3.370 \\
\hline 2.106 & -3.427 \\
\hline 2.107 & -3.647 \\
\hline 2.108 & -3.938 \\
\hline 2.109 & -4.220 \\
\hline 2.110 & -4.527 \\
\hline 2.112 & -4.938 \\
\hline 2.115 & -5.391 \\
\hline 2.120 & -5.539 \\
\hline 2.123 & -5.604 \\
\hline
\end{tabular}

Ionics 


$\begin{array}{ll}2.128 & -5.659 \\ 2.134 & -5.704 \\ 2.144 & -5.747 \\ 2.155 & -5.802 \\ 2.166 & -5.866 \\ 2.205 & -6.079 \\ 2.287 & -6.496 \\ 2.383 & -6.866\end{array}$

Ionics 
Otomo, 2005, $30 \mathrm{~mol} \% \mathrm{H} 2 \mathrm{O}$

$\begin{array}{cc}\mathrm{X} \text { axis } & \mathrm{Y} \text { axis } \\ 1000 / \mathrm{T} & \text { log sigma } \\ 1.747 & -1.476 \\ 1.777 & -1.554 \\ 1.805 & -1.508 \\ 1.838 & -1.630 \\ 1.871 & -1.710 \\ 1.908 & -1.775 \\ 1.943 & -1.832 \\ 1.961 & -1.852 \\ 1.976 & -1.888 \\ 1.983 & -2.412 \\ 2.022 & -5.195 \\ 2.062 & -5.243 \\ 2.106 & -5.316 \\ 2.199 & -5.446 \\ 2.354 & -5.654\end{array}$

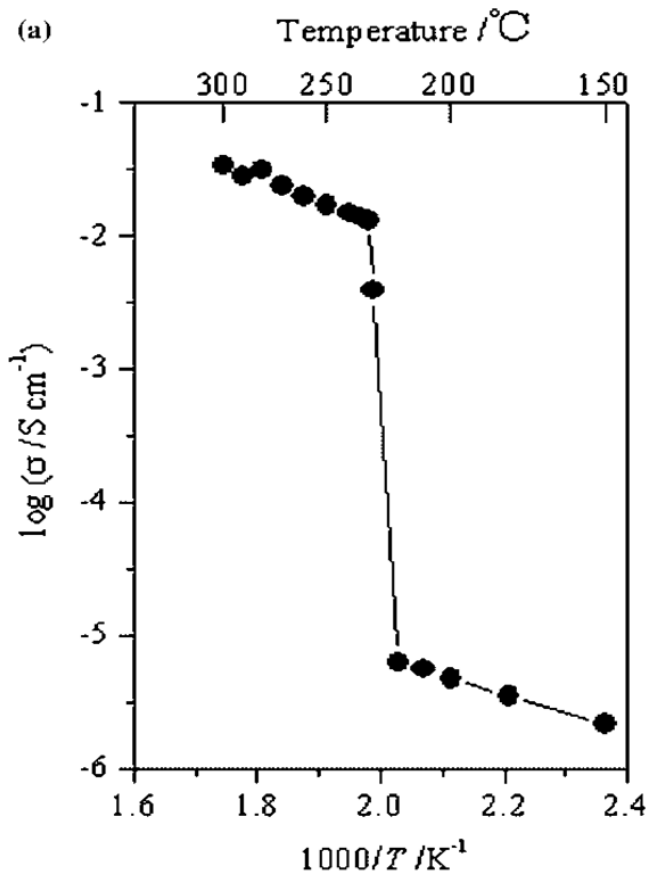

(b)

Temperature $1 \mathrm{C}$

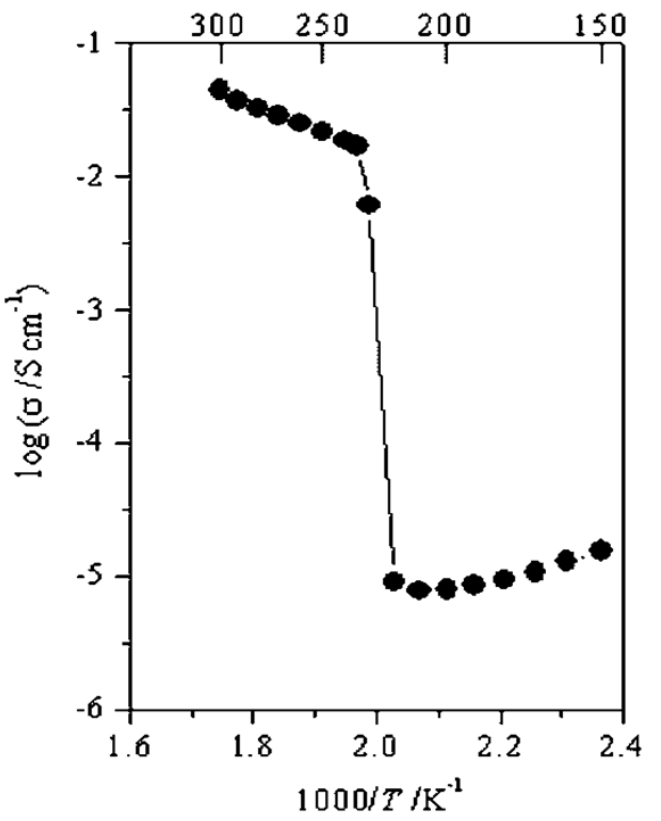

Fig. 3. Temperature dependence of CDP conductivity in a heating process. (a) $30 \mathrm{~mol}^{\circ} \mathrm{H}_{2} \mathrm{O} / \mathrm{Ar}$-balance; (b) $90 \mathrm{~mol} \% \mathrm{H}_{2} \mathrm{O} / \mathrm{Ar}$-balance; total pressure: atmospheric pressure. 


$\begin{array}{cc}\text { Otomo, 2005, } 90 \text { mol\% } \mathrm{H} 2 \mathrm{O} \\ \mathrm{X} \text { axis } & \mathrm{Y} \text { axis } \\ 1000 / \mathrm{T} & \text { log sigma } \\ 1.745 & -1.355 \\ 1.775 & -1.434 \\ 1.805 & -1.494 \\ 1.838 & -1.550 \\ 1.872 & -1.606 \\ 1.908 & -1.669 \\ 1.944 & -1.734 \\ 1.965 & -1.776 \\ 1.984 & -2.216 \\ 2.024 & -5.033 \\ 2.063 & -5.098 \\ 2.106 & -5.091 \\ 2.151 & -5.059 \\ 2.214 & -5.020 \\ 2.266 & -4.962 \\ 2.317 & -4.882 \\ 2.374 & -4.801\end{array}$
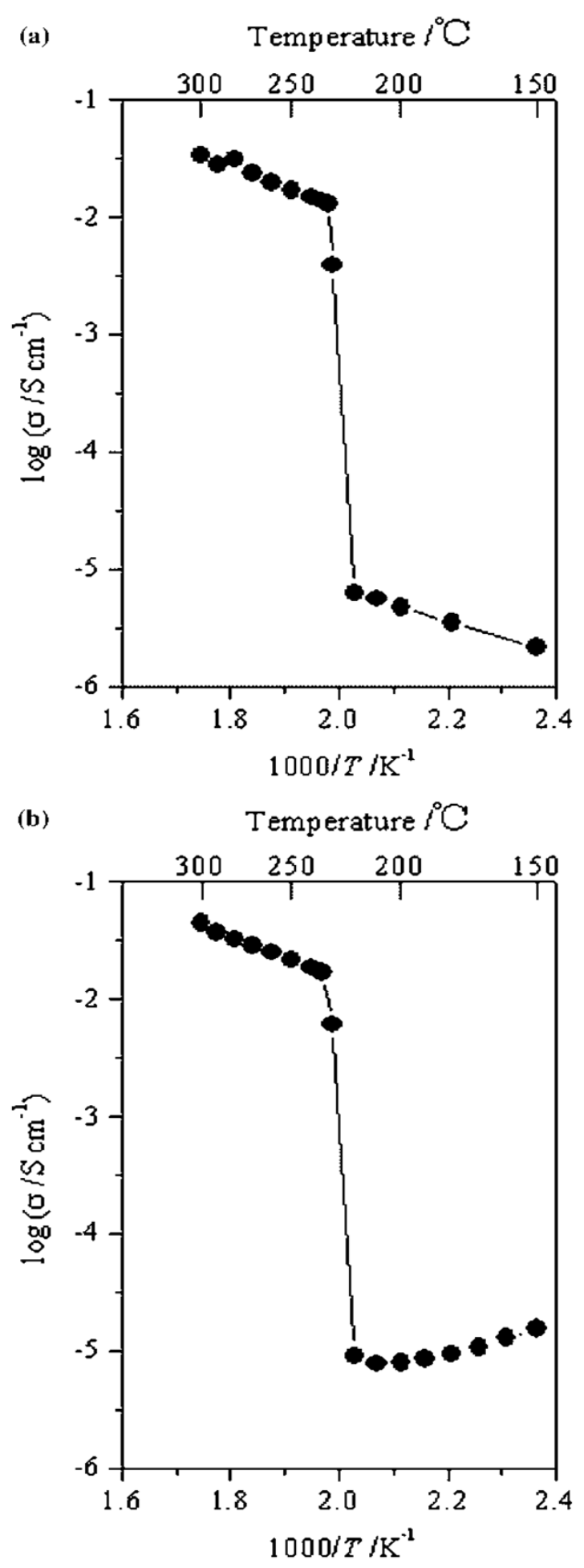

Fig. 3. Temperature dependence of CDP conductivity in a heating process. (a) $30 \mathrm{~mol}_{0} / \mathrm{H}_{2} \mathrm{O} / \mathrm{Ar}$-balance; (b) $90 \mathrm{~mol}_{0} \mathrm{H}_{2} \mathrm{O} / \mathrm{Ar}$-balance; total pressure: atmospheric pressure. 


$\begin{array}{cccccc}\begin{array}{l}\text { Otomo, 2003,30mol\%H2O, InsigmaT } \\ \text { X axis } \\ \text { Y axis }\end{array} & & & & \\ 1000 / \mathrm{T} & \text { In sigma T } & \log \text { sigma T } & \mathrm{T} & \log \mathrm{T} & \log \text { sigma } \\ 1.912 & 2.348 & 1.020 & 523.059 & 2.719 & -1.699 \\ 1.949 & 2.160 & 0.938 & 512.997 & 2.710 & -1.772 \\ 1.988 & 1.976 & 0.858 & 502.919 & 2.701 & -1.843 \\ 2.028 & -6.064 & -2.633 & 493.012 & 2.693 & -5.326 \\ 2.070 & -6.312 & -2.741 & 483.019 & 2.684 & -5.425 \\ 2.114 & -6.524 & -2.833 & 472.973 & 2.675 & -5.508 \\ 2.207 & -6.884 & -2.989 & 453.029 & 2.656 & -5.645 \\ 2.364 & -7.368 & -3.199 & 423.081 & 2.626 & -5.826\end{array}$

Temperature $/{ }^{\circ} \mathrm{C}$

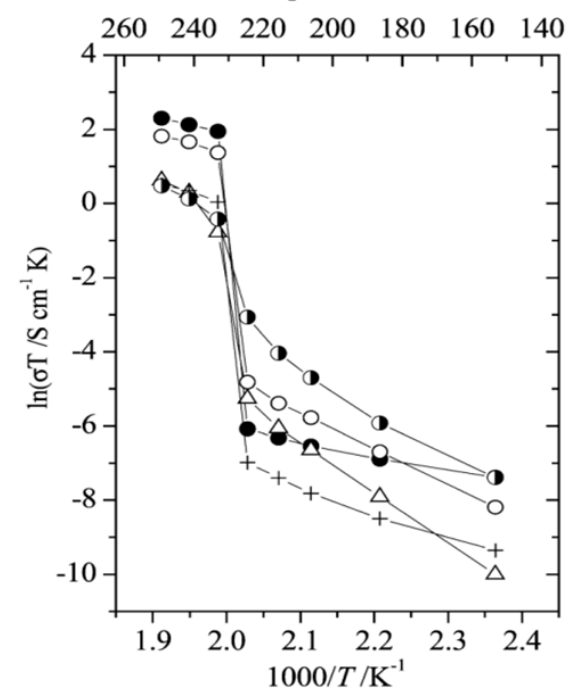

Fig. 7. Temperature dependence of the conductivity of $\mathrm{CsH}_{2} \mathrm{PO}_{4}$ $\mathrm{SiO}_{2}$ composite in $30 \mathrm{~mol} \% \mathrm{H}_{2} \mathrm{O} / \mathrm{Ar}$ on heating process. $\bullet$ : Pure $\mathrm{CsH}_{2} \mathrm{PO}_{4} ; \Delta:(1-x) \mathrm{CsH}_{2} \mathrm{PO}_{4} / x \mathrm{~S} 1$ at $x=0.33 ;+:(1-x) \mathrm{CsH}_{2} \mathrm{PO}_{4}$ $x \mathrm{~S} 2$ at $x=0.33 ; 0:(1-x) \mathrm{CsH}_{2} \mathrm{PO}_{4} / x \mathrm{~S} 3$ at $x=0.33$; $(1-x) \mathrm{CsH}_{2} \mathrm{PO}_{4} / x \mathrm{~S} 3$ at $x=0.5$. 
Otomo, 2003, 30 mol\% H2O(sigma)

$\begin{array}{ccccc}\mathrm{X} \text { axis } & & & \mathrm{Y} \text { axis } & \\ \mathrm{t} & 1000 / \mathrm{T} & \log \text { conductivity } & \text { sigma } & \log \text { sigma } \\ 250.000 & 523.150 & 1.911 & 0.008 & -2.097\end{array}$

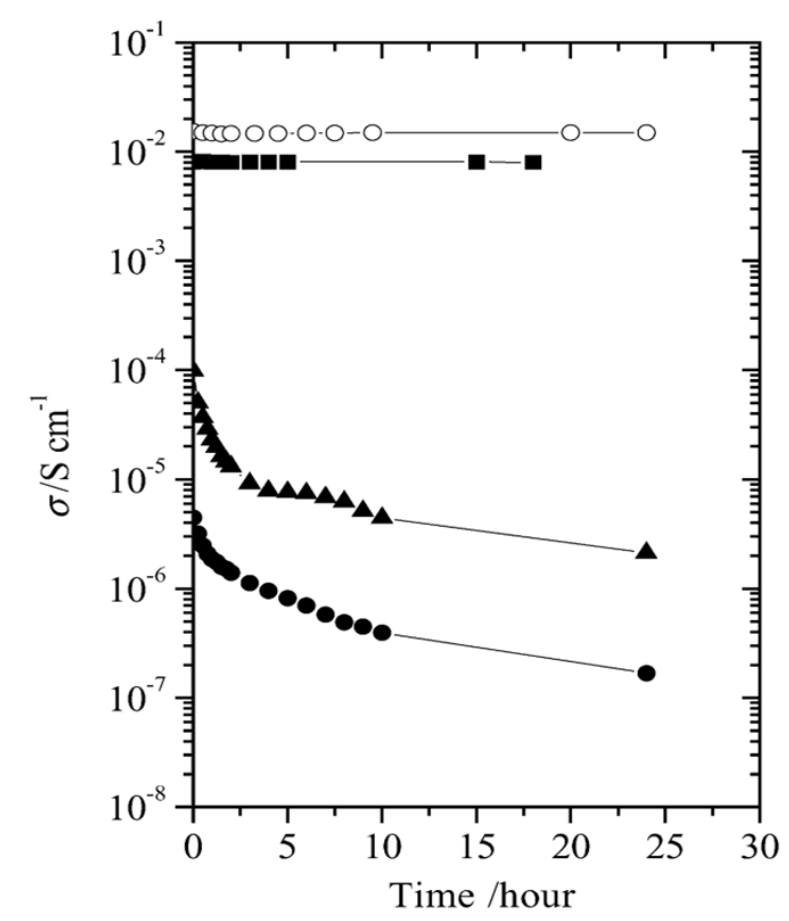

Fig. 2. Time dependence of the conductivity of polycrystalline $\mathrm{CsH}_{2} \mathrm{PO}_{4}$ at $250{ }^{\circ} \mathrm{C}$ with various humidity conditions. 0 : Dry Ar; A : $3 \mathrm{~mol} \% \mathrm{H}_{2} \mathrm{O} / \mathrm{Ar}$; : $30 \mathrm{~mol} \% \mathrm{H}_{2} \mathrm{O} / \mathrm{Ar}$; O: $90 \mathrm{~mol} \% \mathrm{H}_{2} \mathrm{O} / \mathrm{Ar}$. 
Otomo, 2003, 90 mol\% H2O(sigma)

$\begin{array}{ccccc}\mathrm{X} \text { axis } & & & \mathrm{Y} \text { axis } & \\ \mathrm{t} & 1000 / \mathrm{T} & \text { log conductivity } & \text { sigma } & \text { log sigma } \\ 250.000 & 523.150 & 1.911 & 0.014 & -1.854\end{array}$

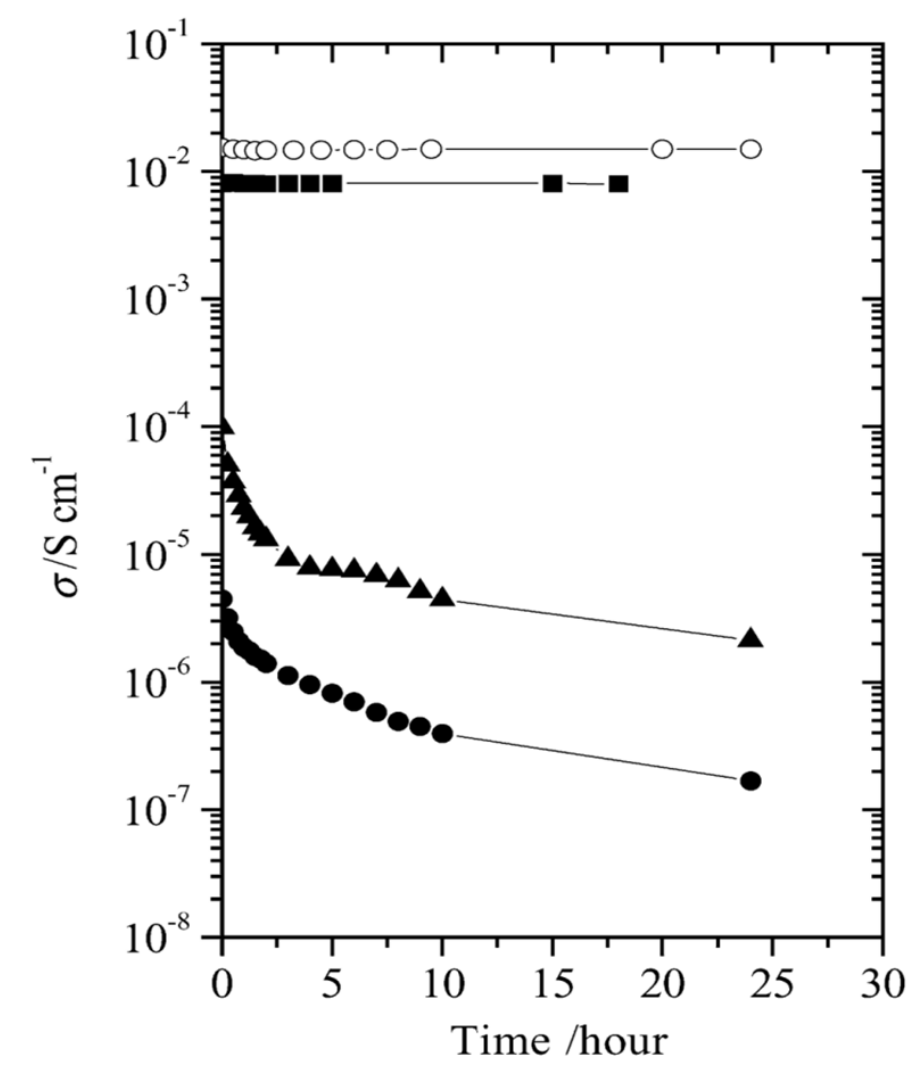

Fig. 2. Time dependence of the conductivity of polycrystalline $\mathrm{CsH}_{2} \mathrm{PO}_{4}$ at $250{ }^{\circ} \mathrm{C}$ with various humidity conditions. $\bullet$ : Dry Ar; A : $3 \mathrm{~mol} \% \mathrm{H}_{2} \mathrm{O} / \mathrm{Ar}$; : $30 \mathrm{~mol} \% \mathrm{H}_{2} \mathrm{O} / \mathrm{Ar}$; O: $90 \mathrm{~mol} \% \mathrm{H}_{2} \mathrm{O} / \mathrm{Ar}$. 
Ortiz, 1999

$X$ axis

$$
\mathrm{t}
$$

89.907

100.000

108.972

120.140

125.140

130.140

135.187

140.280

145.234

150.187

155.234

160.140

165.187

170.140

175.140

180.187

185.093

190.187

195.093

200.140

205.093

210.000

215.140

220.093

225.187

230.187

245.187

250.327

255.327

260.327

255.327

250.374

246.262

240.327

235.327

230.234

225.280

220.093

215.187

210.093

200.093

190.140

180.093

170.093

160.140

150.234

140.234

\begin{tabular}{cc}
$\mathrm{T}$ & $1000 / \mathrm{T}$ \\
363.057 & 2.754 \\
373.150 & 2.680 \\
382.122 & 2.617 \\
393.290 & 2.543 \\
398.290 & 2.511 \\
403.290 & 2.480 \\
408.337 & 2.449 \\
413.430 & 2.419 \\
418.384 & 2.390 \\
423.337 & 2.362 \\
428.384 & 2.334 \\
433.290 & 2.308 \\
438.337 & 2.281 \\
443.290 & 2.256 \\
448.290 & 2.231 \\
453.337 & 2.206 \\
458.243 & 2.182 \\
463.337 & 2.158 \\
468.243 & 2.136 \\
473.290 & 2.113 \\
478.243 & 2.091 \\
483.150 & 2.070 \\
488.290 & 2.048 \\
493.243 & 2.027 \\
498.337 & 2.007 \\
503.337 & 1.987 \\
518.337 & 1.929 \\
523.477 & 1.910 \\
528.477 & 1.892 \\
533.477 & 1.874 \\
528.477 & 1.892 \\
523.524 & 1.910 \\
519.412 & 1.925 \\
513.477 & 1.948 \\
508.477 & 1.967 \\
503.384 & 1.987 \\
498.430 & 2.006 \\
493.243 & 2.027 \\
488.337 & 2.048 \\
483.243 & 2.069 \\
473.243 & 2.113 \\
463.290 & 2.158 \\
453.243 & 2.206 \\
443.243 & 2.256 \\
433.290 & 2.308 \\
413.384 & 2.362 \\
& 2.419 \\
\hline
\end{tabular}

$\mathrm{Y}$ axis

log sigma

$-6.457$

$-6.187$

$-6.033$

$-5.760$

$-5.680$

$-5.593$

$-5.497$

$-5.407$

$-5.350$

$-5.277$

$-5.193$

$-5.120$

$-5.047$

$-4.960$

$-4.840$

$-4.690$

$-4.223$

$-3.960$

$-3.477$

$-2.633$

$-2.600$

$-2.547$

$-2.513$

$-2.483$

$-2.440$

$-2.400$

$-2.247$

$-2.150$

$-2.080$

$-1.997$

$-2.160$

$-2.280$

$-2.247$

$-2.197$

$-2.223$

$-3.103$

$-4.530$

$-4.527$

$-4.577$

$-4.670$

$-4.803$

$-4.773$

$-4.917$

$-5.197$

$-5.477$

$-5.660$

$-6.767$

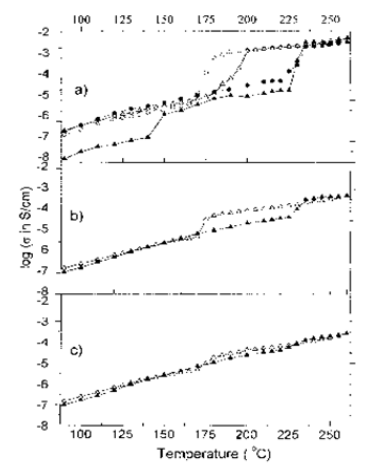

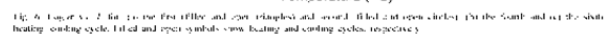

Ionics 


$\begin{array}{cccc}130.234 & 403.384 & 2.479 & -6.930 \\ 120.187 & 393.337 & 2.542 & -7.107 \\ 110.093 & 383.243 & 2.609 & -7.223 \\ 100.000 & 373.150 & 2.680 & -7.463 \\ 89.953 & 363.103 & 2.754 & -7.800\end{array}$

Ionics 


\begin{tabular}{cccccc} 
Baranov, 1989 & \multicolumn{5}{c}{} \\
X axis & Y axis & & & & \\
$1000 / T$ & In sigma T & log sigma T & T & log T & log sigma \\
1.893 & 2.801 & 1.216 & 528.175 & 2.723 & 1.507 \\
1.903 & 2.756 & 1.197 & 525.505 & 2.721 & 1.524 \\
1.918 & 2.702 & 1.173 & 521.388 & 2.717 & 1.544 \\
1.927 & 2.658 & 1.154 & 518.868 & 2.715 & 1.561 \\
1.940 & 2.598 & 1.128 & 515.412 & 2.712 & 1.584 \\
1.950 & 2.557 & 1.110 & 512.791 & 2.710 & 1.600 \\
1.961 & 2.509 & 1.089 & 509.884 & 2.707 & 1.618 \\
1.971 & 2.473 & 1.074 & 507.241 & 2.705 & 1.631 \\
1.980 & 2.432 & 1.056 & 504.932 & 2.703 & 1.647 \\
1.996 & -5.905 & -2.564 & 500.979 & 2.700 & 5.264 \\
2.023 & -6.237 & -2.708 & 494.208 & 2.694 & 5.402 \\
2.049 & -6.495 & -2.820 & 487.975 & 2.688 & 5.508 \\
2.076 & -6.845 & -2.972 & 481.758 & 2.683 & 5.655 \\
2.097 & -7.094 & -3.080 & 476.788 & 2.678 & 5.759 \\
2.132 & -7.497 & -3.255 & 469.124 & 2.671 & 5.927 \\
2.163 & -7.853 & -3.410 & 462.410 & 2.665 & 6.075 \\
2.205 & -8.363 & -3.631 & 453.585 & 2.657 & 6.288 \\
2.226 & -8.627 & -3.746 & 449.177 & 2.652 & 6.398 \\
2.247 & -8.858 & -3.846 & 445.031 & 2.648 & 6.495 \\
2.275 & -9.170 & -3.982 & 439.506 & 2.643 & 6.625 \\
2.308 & -9.561 & -4.152 & 433.212 & 2.637 & 6.788 \\
2.360 & -10.095 & -4.383 & 423.723 & 2.627 & 7.010 \\
2.388 & -10.546 & -4.579 & 418.817 & 2.622 & 7.201 \\
2.422 & -10.845 & -4.709 & 412.907 & 2.616 & 7.325 \\
2.457 & -11.275 & -4.896 & 406.991 & 2.610 & 7.505 \\
2.488 & -11.690 & -5.076 & 401.927 & 2.604 & 7.680 \\
2.524 & -12.043 & -5.229 & 396.129 & 2.598 & 7.827 \\
2.561 & -12.458 & -5.410 & 390.449 & 2.592 & 8.001 \\
2.594 & -12.862 & -5.585 & 385.560 & 2.586 & 8.171 \\
2.629 & -13.295 & -5.773 & 380.309 & 2.580 & 8.353 \\
2.694 & -14.009 & -6.083 & 371.226 & 2.570 & 8.653 \\
2.735 & -14.475 & -6.285 & 365.624 & 2.563 & 8.848 \\
2.755 & -6.748 & -6.404 & 362.925 & 2.560 & 8.964
\end{tabular}

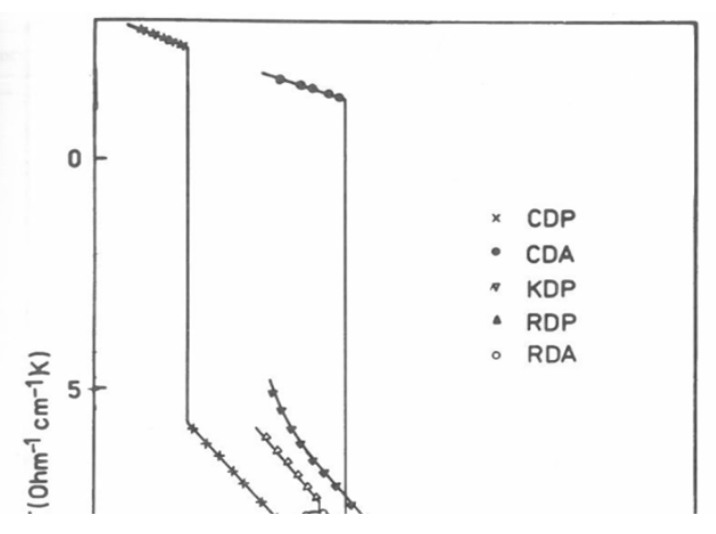

Ionics 


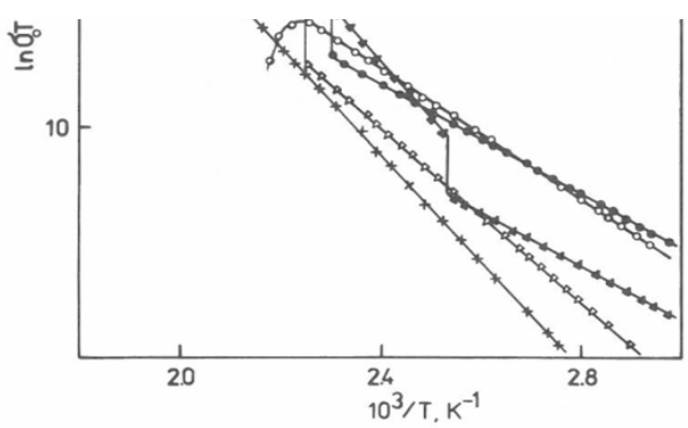

FIGURE 1 Temperature dependences of the conductivity for some crystals of KDP-family 


$\begin{array}{lccccc}\begin{array}{l}\text { Baranov, } 1988 \\ \text { X axis }\end{array} & \begin{array}{r}\text { Y axis } \\ \text { In sigma T }\end{array} & \text { log sigma T } & \mathrm{T} & \text { log T } & \text { log sigma } \\ 1000 / \mathrm{T} & 2.624 & 1.140 & 521.850 & 2.718 & -1.578 \\ 1.916 & 2.429 & 1.055 & 511.464 & 2.709 & -1.654 \\ 1.955 & 2.332 & 1.012 & 502.101 & 2.701 & -1.688 \\ 1.992 & 2.244 & 0.974 & 494.157 & 2.694 & -1.720 \\ 2.024 & 2.098 & 0.911 & 485.065 & 2.686 & -1.775 \\ 2.062 & -1.776 & -0.771 & 477.646 & 2.679 & -3.450 \\ 2.094 & -3.932 & -1.707 & 500.493 & 2.699 & -4.407 \\ 1.998 & -6.615 & -2.872 & 495.363 & 2.695 & -5.567 \\ 2.019 & -7.034 & -3.054 & 485.878 & 2.687 & -5.741 \\ 2.058 & -7.415 & -3.220 & 476.302 & 2.678 & -5.897 \\ 2.100 & -7.415 & -3.220 & 475.855 & 2.677 & -5.897 \\ 2.101 & -8.098 & -3.516 & 470.126 & 2.672 & -6.188 \\ 2.127 & -7.922 & -3.440 & 465.810 & 2.668 & -6.108 \\ 2.147 & -8.332 & -3.618 & 457.105 & 2.660 & -6.278 \\ 2.188 & -8.780 & -3.813 & 455.872 & 2.659 & -6.471 \\ 2.194 & -8.741 & -3.796 & 449.115 & 2.652 & -6.448 \\ 2.227 & -9.122 & -3.961 & 442.073 & 2.645 & -6.606 \\ 2.262 & -9.473 & -4.113 & 435.155 & 2.639 & -6.752 \\ 2.298 & & & & & \end{array}$

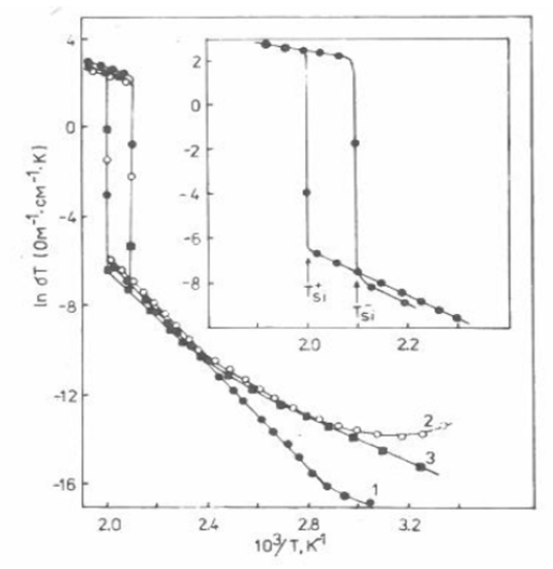

FIGURE 4 Temperature dependences of the bulk conductivity CDP in $\bar{a}(1), \bar{b}(2)$ and $\bar{c}(3)$-directions. 